\begin{tabular}{l}
\hline http://kitaibelia.unideb.hu/ \\
ISSN 2064-4507 (Online) • ISSN 1219-9672 (Print) \\
(c) Department of Botany, University of Debrecen, Hungary \\
27(1): 27-67.; 2022 \\
DoI: $10.17542 /$ kit.27.003 \\
research paper • eredeti közlemény
\end{tabular}

\title{
Adatok a Szuha-vízgyűjtő és környéke flórájához
}

\author{
SZENTGYÖRGYI Péter ${ }^{1}$ \& BÁTORI Gábor ${ }^{2}$ \\ (1) H-3721 Dövény, Dózsa György út 27. \\ (2) H-3721 Felsőnyárád, József Attila út 46.
}

\section{Contributions to the flora of the Szuha watershed and adjacent territories (NE Hungary)}

\begin{abstract}
This paper presents new floristic data of 415 taxa from the Putnok Hills and Sajó Valley microregions (Northern Hungary). Records were collected between 1991 and 2021. In the first part new occurrences of legally protected (e.g., Cypripedium calceolus, Iris aphylla subsp. hungarica, Lycopodium clavatum, Thalictrum aquilegiifolium, Pyrola rotundifolia, Scorzonera purpurea, Stipa pulcherrima) and not protected but locally rare or data-deficient species (e.g., Myosurus minimus, Thalictrum simplex, Sisymbrium loeselii, Camelina microcarpa, Potentilla collina, Trifolium striatum, Geranium pratense, G. dissectum, G. divaricatum, Viola pumila, Epilobium roseum, Myriophyllum spicatum, Pimpinella major, Berula erecta, Trinia ramosissima, Centaurium pulchellum, Nepeta cataria, Limosella aquatica, Veronica scutellata, Orobanche arenaria, Utricularia vulgaris, Galium elongatum, Cephalaria transsylvanica, Dipsacus fullonum, Xanthium saccharatum, Alisma lanceolatum, Elodea canadensis, Potamogeton pectinatus, $P$. berchtoldii, P. lucens, P. nodosus, Zannichellia palustris, Sisyrinchium bermudiana, Melica picta, Elymus elongatus, Leersia oryzoides, Typha laxmannii, Eriochloa villosa) are presented. This chapter contains data on 246 species from which 8 are new for the flora of the Tornense flora region and 47 for its subregion, the Putnok Hills. Further contributions to the distribution data of Atlas Florae Hungariae are presented in Electronic Appendix. This section contains raw occurrence data of 169 species.
\end{abstract}

Keywords: distribution, floristic record, protected species, Putnok Hills, rare species, Sajó Valley

Összefoglalás - Cikkünkben a Putnoki-dombság és kisebb részben a Sajó-völgy flórájához szolgáltatunk adatokat, melyeket 1991 és 2021 között gyüjtöttünk, és összesen 415 fajra vonatkoznak. Publikáljuk néhány a Tornense-ből, illetve a Putnoki-dombságból eddig nem közölt vagy ritka faj adatát, illetve kitérünk adathiányos, de gyakoribb fajokra is. Több fokozottan védett, illetve védett faj előfordulását is megemlítjük. Az ebben a részben szereplő 246 faj közül 8 a Tornensére, további 47 pedig a Putnoki-dombságra új. Elektronikus mellékletben 169 növényfajról kiegészítő elterjedési adatokkal szolgálunk Magyarország edényes növényfajainak elterjedési atlaszához.

Kulcsszavak: elterjedés, florisztikai adatok, Putnoki-dombság, ritka fajok, Sajó-völgy, védett fajok 


\section{Bevezetés}

Cikkünkben az 1991 és 2021 között gyűjtött florisztikai adatainkat tesszük közzé. Az adatok nagy része a Szuha vízgyűjtőterületére vonatkozik. A Szuha a Bódva mellett a Sajó legjelentősebb baloldali mellékvize. Szuhafő felett ered, és eredetileg Sajószentpéternél folyt a Sajóba, de az 1950-es évek végén a Szuha torkolati szakaszának átépítése következtében a torkolat Kazincbarcikához - a Sajón mintegy 5 km-rel feljebb - került. Múcsony határában vízosztó müvet építettek, azóta a patak vízhozamának nagy része az új, mesterséges 1,8 km-es mederbe kerül, míg a patak régi, 8,2 km-es medréből holtág lett. Ennek következtében a patak eredeti 40 km-es hossza lecsökkent. A vízgyűjtő területe 212 km².

A terület földrajzilag az Észak-magyarországi-középhegység nagytáj Észak-magyarországi-medencék középtájának Borsodi-dombság kistájcsoportjában található (DövÉNYI 2010). CsORBA et al. (2018) természeti tájak rendszertani feloszása szerint a Putnoki-dombság a Sajó-völgymedence kistájjal együtt a Gömör-Borsodi-medence kistájcsoportot alkotja, a Nógrád-Abaúji-medencesor középtáj része, és a Gömör-Tornai-karszttal együtt a BelsőÉszaknyugati-Kárpátok nagytájrészlet magyarországi északi részén terül el. A Szuha vízgyüjtője a Putnoki-dombság kistáj közepét, mintegy szívét alkotja, míg kisebb, déli része a Sajóvölgybe nyúlik. A Putnoki-dombságot északról a Gömör-Tornai-karszt részei (Aggteleki Fedett-karszt, Galyaság és Rudabányai-hegység) határolják. Keletről a Bódva-völgy és a Csereháthoz sorolható Szendrői-rögvidék Bódván átnyúló tömbje, délről a Sajó-völgy, nyugatról pedig Szlovákia államhatára jelenti a határt. A terület jelentős része 200-250 méter tengerszint feletti magasságban található, völgyekkel felszabdalt medencedombság (a vízgyűjtő legmagasabb pontja 375 m), amelyre a közel párhuzamosan futó DK-i - D-i csapású völgyek rendszere jellemzo. Ezek a völgyek a Szuha patak völgye, a Csörgős-patak völgye, a Zúgóvölgy (Imola-patak völgye), a Rudabányai-völgy (Ormos-patak völgye) és a Kazinczy-völgy (Mák-patak völgye).

Növényföldrajzilag a terület a Pannóniai flóratartomány (Pannonicum) Északiközéphegység flóravidékének (Matricum) Tornai-karszt flórajárásába (Tornense) tartozik. Megjegyzendő azonban, hogy a terület mind alapkőzetében, mind a kialakult talajaiban, éghajlati adottságaiban és növényzetében is jelentősen eltér a Gömör-Tornai-karszttól. Magunk a Putnoki-dombság északi határát a fenti irodalmak (DövÉNYI 2010, CsORBA et al. 2018) által megállapítotthoz képest délebbre helyezzük, mert az Aggtelektől délre eső Kavicshát (Aggteleki Fedett-karszt), illetve a Rét-patak völgye és az azt szegélyező dombsorok (Galyaság déli része) mind geológiai-geomorfológiai, mind növényzeti szempontból jóval közelebb állnak a Gömör-Tornai-karszthoz. Ezek alapján mi is VIRóK et al. (2014) felosztását követjük.

A Szuha vízgyűjtőjén kimutatott edényes növényfajok száma az irodalomban ismertetett publikációk, illetve saját kutatásaink alapján eléri az ezret, ez a szám különösen akkor tekinthető magasnak, ha figyelembe vesszük, hogy a területről néhány - a hasonló középhegységi dombságokban megtalálható - élőhely gyakorlatilag teljesen hiányzik. Különösen szembetűnő a bükkösök és sziklás élőhelyek szinte teljes hiánya, de például homokköves felszíneket sem találhatunk, így ezen élőhelyekhez kötődő fajok nagyrészt nem tagjai az itteni flórának.

A térségnek még több mint a felét ma is erdők borítják, de ezek flórája szegényes. Az újabb kutatások szerint a terület zonális társulása a gyertyános-kocsánytalan tölgyes, nem pedig a cseres-tölgyes, emellett telepített fenyvesek és ültetett akácosok fordulnak elő, a vízfolyásokat pedig füzligetek kísérik. A patakvölgyek szubmontán égerligetei jelentős botanikai értékeket képviselnek (szuhafői Szuha-völgy, alsószuhai Bakóc-völgy), az utóbbi területen 200-220 m tengerszint feletti magasságban a speciális mikroklimatikus viszonyok következtében montán-kárpáti fajok is előfordulnak. Értékesek, de sérülékenyek a nedves rétek is, 
így Alsószuha Alsó-rét fűzlápfoltja, a láp- és mocsárrétek legfajgazdagabbjai: Jákfalva Falu-rét és Alsó-rét, Dövény Alsó-rét és Felső-rét, Felsőnyárád Kelecsényi-úton-aluli-dűlő. Jellemzőek és a flóraszínezés szempontjából fontosak még a patak menti magaskórós társulások is. A völgyek közötti domboldalakat nagyrészt másodlagosan kialakult száraz gyepek borítják. Ezek az élőhelyek különösen gazdagok sztyepfajokban, főleg Zádorfalva határában, de Szuhafő, Alsószuha, Trizs, Ragály, Felsőnyárád és Kurityán környékén is. Löszös területek elsősorban a terület déli részén találhatók, a legkiemelkedőbb a múcsonyi Meleg-oldal. A vízi élőhelyek hínár- és vízparti növényzete is sok érdekességet rejt, illetve rejtett, a legérdekesebbek voltak a külszíni szénbányászat következtében Izsófalva határában létrejött Alsó-réti és Kállói-tagi bányatavak, amelyeket 2018-19-ben rekultiváltak (megszüntettek). Emiatt néhány faj eltűnt a területről, ezeket az adott fajokat ismertető részeknél jelezzük.

\section{Irodalmi áttekintés, kutatástörténet}

A Putnoki-dombság botanikai kutatása gyakorlatilag az 1990-es évek végéig csak alkalmi és szúk területre irányult. Viszonylag intenzív kutatás csak a jelen közleményünkben nem említett keleméri Mohosokon folyt, innen 1878-ból Hazslinszky Frigyes a Carex limosa-t említi, majd 1911-ben Thaisz Lajos, 1924-ben Boros Ádám, 1925-ben Zólyomi Bálint végzett kutatásokat, utána még számos botanikusunk gazdagította a Mohosokra vonatkozó ismereteinket. A Szuha-vízgyűjtő területére vonatkozó botanikai adatokat először a múlt század elejéről találunk. Budai József 1908 és 1915 között több alkalommal felkereste Dövényt, Felsőnyárádot, Izsófalvát, Kurityánt, Múcsonyt és Szuhakállót, gyűjtéseit részben publikálta (BUDAI 1914). Adatainak további része Soó et al. (1943) munkájából ismert, akik feldolgozták Budai jegyzeteit, revideálva herbáriumi anyagának egy részét is. Így vált ismertté a területről az Achillea collina, Callitriche palustris, Carex tomentosa, Centaurea scabiosa, Cirsium eriophorum, Crataegus laevigata, Erigeron annuus, Galium boreale, Genista germanica, Lathyrus nissolia, Luzula multiflora, Misopates orontium, Peucedanum carvifolium, Potentilla alba, P. leucopolitana, Pseudolysimachion spicatum, Saxifraga bulbifera, Senecio sarracenicus, Seseli annuum, Solidago virgaurea és a Trifolium fragiferum. Thaisz Lajos 1911-ben Szuhafón kutatott, majd HULJÁK (1926) és ZóLYOMI (1928) Putnokról végeztek gyüjtéseket és közöltek adatokat. Utána az 1930-es évektől az 1970-es évekig a kutatások elsősorban a Kavicsháton és környékén folytak, amelyek kisebb-nagyobb részben érintették (érinthették?) a Szuha vízgyűjtőjét is. Zólyomi Bálint 1928-ban Alsószuhán végzett rövid kutatást, amelynek eredménye a Taraxacum laevigatum előkerülése. Kárpáti Zoltán 1929-ben Rudabányát, Soó Rezső 1936-ban Imolát és Rudabányát kereste fel, utóbbi adatok szintén Soó et al. (1943) művében kerültek publikálásra. A két település a Putnoki-dombság határán fekszik, és a gyüjtött fajok között több olyan is található, amely nem fordul elő a dombságban, ezért az Imolán gyújtött fajok (legalább részben) az Aggteleki Fedett-karsztra, míg a Rudabányán gyüjtöttek a Rudabányai-hegységre vonatkozhatnak. Jávorka Sándor és Zólyomi Bálint 1949-ben, míg Boros Ádám 1953-ban Trizs környékén végeztek gyüjtéseket, az általuk gyűjtött fajokról sem dönthető el egyértelműen, hogy a Putnoki-dombság területére vonatkoznak-e, mivel a Trizstől északra lévő területek a Gömör-Tornai-karszthoz tartoznak (Kavicshát vagy Aggteleki Fedett-karszt). Pár évtized szünet után BudAY (1979) az 1977-es imolai és trizsi felméréseit is publikálja, így az Allium oleraceum, Cephalanthera damasonium, C. rubra és a Cirsium pannonicum előfordulását, utána Less Nándor és Matus Gábor 1992-ben Rudabánya környékén végzett kutatásokat. Majd az Aggteleki Nemzeti Park megalakulása után elsősorban a nemzeti park területéhez tartozó, a vízgyüjtő északi, védelem alá került részeinek (Imola, Szuhafő és Trizs környéke) kutatása folyt Vojtkó András és Somlyay Lajos, illetve a később nagyrészt a Natura 2000 hálózatba jelölt területek feltárása Penksza Károly és Malatinszky Ákos jóvol- 
tából. A kutatások kiemelkedő eredménye volt a hazai flórára új Geum rivale megtalálása (Penksza \& Somlyay 1999, Penksza et al. 1999/2000). PenKSZA et al. (1999/2000) a Cardamine amara, C. glanduligera, Carex cespitosa, C. elongata, Dryopteris dilatata, Glyceria declinata, Listera ovata, Oenanthe banatica, Prunus fruticosus és a Senecio erucifolius, SomlYay \& LőKÖS (1999) és SOMLYAY (2000) a Lycopodium clavatum és a Carex hordeistichos, PENKSZA \& MaLATinszKY (2001) a Bifora radians, Carex buekii, Gentiana cruciata, Hippocrepis commosa, Paris quadrifolia és a Trifolium dubium, MaLATinszKY (2004) az Eriophorum angustifolium, Euphorbia salicifolia, Rapistrum perenne és a Scutellaria hastifolia, MALATINSZKY (2007) az Artemisia pontica, Carex nigra, C. vesicaria, Chamaecytisus ratisbonensis, Cirsium oleraceum, Crataegus $\times$ media, Crepis praemorsa, Epipactis albensis, Equisetum ramosissimum, Galium uliginosum, Gentianopsis ciliata, Helianthus decapetalus, Monotropa hypopitys, Myosotis nemorosa, Peplis portula, Potentilla rupestris, Pulsatilla zimmermannii, Ribes uva-crispa, Senecio aquaticus, S. germanicus, Valerianella rimosa és a Vicia cassubica, VojtKó $(2004,2008)$ a Dactylorhiza fuchsii, és a Polystichum braunii fajokkal bővítik a vízgyűjtő fajlistáját. Ugyanakkor az Aggteleki Nemzeti Park Igazgatóság dolgozói is végeztek kutatásokat a területen, amelyek során VIRóK et al. (2004, 2010) és VIRóK \& FARKAS (2007) az Actaea spicata, Aquilega vulgaris, Astrantia major, Calamagrostis canescens, Carex flava, C. hostiana, Catabrosa aquatica, Cnidium dubium, Epilobium ciliatum, Galium rivale, G. spurium, Marrubium peregrinum, Nigella arvensis, Orchis ustulata, Pimpinella major, Ranunculus arvensis, R. rionii, Sparganium emersum, Stellaria alsine és a Succisella inflexa, míg FARKAS (2010) a Dryopteris expansa és az Epipactis helleborine fajok előfordulásáról szolgáltatnak adatokat. Szentgyörgyi Péter védett fajok vízgyűjtőre vonatkozó előfordulásait publikálja (SZENTGYÖRGYI 1994, 1996a, b, c), így említi az Allium sphaerocephalon, Anemone sylvestris, Aquilega vulgaris, Aster amellus, Carlina acaulis, Centaurea triumfettii, Cephalanthera damasonium, C. longifolia, Chamaecytisus albus, Dactylorhiza incarnata, Dianthus deltoides, Dictamnus albus, Eriophorum latifolium, Gymnadenia conopsea, Inula helenium, Iris sibirica, I. variegata, Jurinea mollis, Lilium martagon, Linum flavum, L. hirsutum, L. tenuifolium, Neottia nidus-avis, Orchis elegans, $O$. morio, $O$. purpurea, O. tridentata, O. ustulata, Ornithogalum brevistylum, Phlomis tuberosa, Platanthera bifolia, Polygala major, Prunella grandiflora és a Stipa pennata fajokat. Szintén Szentgyörgyi a Természetvédelmi Hivatal által kiírt pályázatokban 1999 és 2001 között részben az IRMAG önszerveződési csoport, majd az IRMAG Természetvédelmi Egyesület pályamunkáiban az Agrostemma githago, Allium angulosum, Ceratophyllum demersum, Dactylorhiza majalis, Dianthus collinus, Galega officinalis, Geranium palustre, Gratiola officinalis, Iris aphylla subsp. hungarica, Lathyrus nissolia, Linum austriacum, Orchis militaris, Orobanche lutea, Potamogeton natans, Primula elatior, Pseudolysimachion longifolium, Pulsatilla grandis, Scilla kladnii, Sonchus palustris, Sparganium erectum, Vicia grandiflora és a Viola elatior fajok előfordulási adataival bővíti a terület flórájának ismeretét.

\section{Anyag és módszer}

A fajok nevezéktana és számozása KiRÁLY (2009) munkáját követi. Azon hibrid fajokat, amelyek a műben sorszámmal nem szerepelnek, a szülőfajok sorszámai közé tett keresztező jellel jelöljük (pl. 1522 × 1523), és a nagyobb sorszámú szülőfaj után szerepeltetjük az enumerációban. Cikkünkben a védett és a regionális jelentőségű fajokra vonatkozó adatokat községhatárok szerint közöljük, az egyes településekhez tartozó földrajzi nevek esetében az Aggteleki Nemzeti Park Igazgatóság dúlőkataszteri térképét [2] vettük alapul. Az adatok túlnyomó része a Putnoki-dombság kistájra vonatkozik, emellett a Szuha-vízgyüjtő Sajó-völgyhöz tartozó részeiről származó adatainkat is feltüntettük. Az előfordulások felsorolásánál minden esetben a lelőhely után zárójelben megadtuk a megtaláló nevének rövidítését és a megtalálás 
évszámát, esetenként a növények tőszámait is. Áttekintjük a fajok Szuha-vízgyűjtőre és a Putnoki-dombságra vonatkozó herbáriumi adatait, illetve az elterjedését tárgyaló irodalmi hivatkozásokat. Amennyiben a Putnoki-dombságból nem találtunk herbáriumi és publikált adatokat ( $\mathrm{a}$ *-gal jelölt fajok), akkor a faj szomszédos kistájakra (Sajó-völgy, Aggteleki Fedettkarszt, Galyaság, Rudabányai-hegység, Bódva-völgy, Szendrői-rögvidék) vonatkozó adatait ismertetjük. Ha a szomszédos kistájakról sem találtunk adatokat, akkor a Jósvafői-karszt, Cserehát, Szalonnai-hegység kistájakról ismert előfordulásokat említjük. A herbáriumi adataink az alábbi herbáriumokból származnak:

Magyar Természettudományi Múzeum Növénytára, Budapest

Eötvös Loránd Tudományegyetem Herbáriuma Füvészkert, Budapest

Debreceni Egyetem Herbáriuma, Debrecen - Soó Rezső Herbárium

Magyar Agrár- és Élettudományi (korábban Szent István) Egyetem Herbáriuma, Gödöllő

Mátra Múzeum Herbáriuma, Gyöngyös

A herbáriumokban személyesen nem jártunk, adataink az első 4 herbárium esetében a herbáriumi adatokat is tartalmazó Aggteleki Nemzeti Park Igazgatóság Biotikai Adatbázisából származnak, míg a Mátra Múzeum Herbáriumára vonatkozó adat BáNKÚTI (2000) cikkéből.

A Putnoki-dombságra vonatkozó herbáriumi és irodalmi adatoknál a település-, és amennyiben a forrásban szerepelt, a földrajzi nevet is megadtuk. Amennyiben az eredeti közleményben lévő földrajzi név ettől eltér, és ha a név az Aggteleki Nemzeti Park Igazgatóság dűlőkatasztere szerint beazonosítható, akkor azt zárójelben tüntettük fel. Amennyiben a herbáriumi és irodalmi adatoknál az adat nem a Putnoki-dombságra vonatkozik, a kistáj nevét is megadtuk a település neve előtt, azonban nem tüntettük fel kistáj nevét a nem pontosan lokalizálható herbáriumi (Imola, Soó 1936; Rudabánya, Soó, 1936; Trizs, Jávorka és Zólyomi 1949; Trizs, Boros 1953), illetve irodalmi (Imola, Soó et al. 1943; Rudabánya, Soó et al. 1943) adatok esetében. Az enumeráció összeállításánál a „Flóraatlasz” flóratérképezési adataira csak akkor hivatkozunk, ha a dombságból nincs más publikált adata. Mivel az ott szereplő adatok aggregáltsága miatt a pontos térbeli lokalitásuk sokszor nem meghatározható, nem visszaellenőrizhető, így az általunk gyűjtött részletes adatokkal nem összevethető. Sok esetben a lokalitáshoz megadott községhatárok sem egyeznek meg a valósággal, mivel a „Flóraatlaszban” nem feltétlenül a tényleges lokalitás szerinti község neve van megadva, hanem az adott hálószemen belüli települések közül a legnagyobb területfoglalású. Így az adatbázisból idézett előfordulási adatok községnév szintű említése emiatt hozzávetôleges. A „Flóraatlaszban” szereplő településneveket csak akkor említjük, ha egyértelműen a Putnokidombságra vonatkoznak. Annak érdekében, hogy a Magyarországi Flóratérképezés adatbázisába adataink rögzíthetők legyenek, az adott faj után felsorolva megadtuk a közép-európai flóratérképezés rácsháló-egységeinek kódjait (KEF) formátumban (KIRÁLY \& HORVÁTH 2000). Azon KEF kvadrátok számát, amelyekről a Magyarország edényes növényfajainak online adatbázisa nem tartalmaz a faj előfordulásáról adatot, a kvadrát száma előtti ! jelöléssel láttuk el.

A „Flóraatlaszba” történő beilleszthetőség miatt tartottuk fontosnak, hogy jelen közleményünkben megadjuk a régebbi publikált, illetve az előzőekben említett pályázatokban szereplő adataink pontosabb dűlő és KEF kód szerinti lokalitását is, ezek is az Enumeráció első részében szerepelnek.

A jobb áttekinthetőség érdekében az enumerációt két részre osztottuk. Az első részben (Enumeráció 1) szereplő fajokat részletesen ismertetjük, ezeknél feldolgoztuk az általunk elérhető összes irodalmat és herbáriumot. Az Ineditum részében az összes olyan adatunkat felsoroljuk, ahol korábban nem gyűjtötték vagy közölték a fajt, azonos vagy későbbi évből csak akkor, ha az adott fajról az adott helyen állományadatokkal rendelkezünk, az egyes 
fajok esetében a más által korábban közölt előfordulásokat nem szerepeltetjük, mivel ezen adatok között minden esetben csak néhány év telt el. Az Elektronikus mellékletben elhelyezett második részben (Enumeráció 2) szereplő fajok - az egész területen vagy helyenként általánosan elterjedtek. Ezek esetében csak azon KEF négyzetből illetve négyzetekből származó adatainkat tüntettük fel hivatkozások nélkül, melyekből a „Flóraatlasz” nem jelzi az adott faj előfordulását.

A megtalált érdekesebb és ritkább fajokról fotódokumentációval rendelkezünk, herbáriumi gyűjtéseket nem végeztünk. A fajok nagyobb részét magunk határoztuk, a problematikusabb fajok határozásában, illetve azok helyességének ellenőrzésében fénykép, illetve gyưjtött példány alapján Virók Viktor, az Aggteleki Nemzeti Park Igazgatóság munkatársa volt segítségünkre.

\section{Rövidítések:}

BP: Magyar Természettudományi Múzeum Növénytára, Budapest BPU: Eötvös Loránd Tudományegyetem Herbáriuma Füvészkert, Budapest

DE: Debreceni Egyetem Herbáriuma, Debrecen - Soó Rezső Herbárium

GAH: Magyar Agrár- és Élettudományi (korábban Szent István) Egyetem Herbáriuma, Gödöllő

MM: Mátra Múzeum Herbáriuma, Gyöngyös

* A Putnoki-dombságra új

** A Tornensére új

! A kvadrátszám előtt: Magyarország edényes növényfajainak online adatbázisa [1] nem tartalmaz a faj előfordulásáról adatot az adott kvadrátban

Adatközlők, gyűjtők neveinek rövidítése:

BG: Bátori Gábor

FL: Fügedi László

SzP: Szentgyörgyi Péter

\section{Enumeráció 1}

5. Lycopodium clavatum L. - Herb.: Szuhafő (Vojtkó 2000, BP). Lit.: Szuhafő: Szuha-völgy (SOMLYAY \& LŐKÖS 1999), Imola: Tobóka (MALATINSZKY 2007). Ined.: Ragály: Nagy-legelő (BG 2016). Mészkerülő fenyéren. [!7689.1].

8. Equisetum telmateia Ehrh. - Herb.: Putnok (Zólyomi 1928, BP). Lit.: Alsószuha: Hidegkút-völgy; Serényfalva (VIRóK et al. 2004). Ined.: Alsószuha: Kánya-völgy (SzP 2014). Magaskórósban ezres állományát találtuk. [!7689.1].

29. Thelypteris palustris Schott - Herb.: Kelemér: Mohosok (Boros 1924, BP); Trizs: György-szék-völgy (Virók 2009, DE). Lit.: Alsószuha: Alsó-rét (VIRóK et al. 2004); Trizs: György-szék-völgy (FARKAS 2010). Ined.: Dövény: Alsó-rét, 2 tő (SzP 2010). Patak melletti nádasban. [!7689.3].

56. Dryopteris carthusiana (Vill.) H. P. Fuchs - Herb.: Putnok (Zólyomi 1928, BP); Trizs (Jávorka és Zólyomi 1949, BP); Szuhafő (Somlyay 1999, BP); Trizs: György-szék-völgy (Virók 2009, DE). Lit.: Szuhafő: Szuha-völgy (PENKSZA \& SomlYAY 1999), Alsószuha és Dövény közötti Bakóc-völgy égeresében, Trizs felett égerligetben (PENKSZA et al. 1999/2000); Alsószuha: Bakóc-völgy, Gyámol-völgy; Trizs felett égerligetben (PENKSzA \& MALATinszKY 2001); Alsószuha: Hideg-kút-völgy, Jegenye-völgy; Dövény: Kavacs-domb, Kötél-föld, Pencs-tető; Dövény és Sajógalgóc közötti erdőtömb több pontja; Jákfalva: Nagy-Varcsóvölgy mellékvölgyei; Putnok; Sajókaza (MALATıNSZKY 2007). Ined.: Alsószuha: Büdös-kútoldal (SzP 2010), Kakas-vári-oldal (SzP 2010), Kánya-fő (SzP 2014), Kavacs-oldal (SzP 2014), Putnoki-oldal (SzP 2015), Ritka-dűlő (SzP 2011), Ritka-oldal (SzP 2010); Dövény: 
Háromszög-dúlő (SzP 2012), Mély-völgy (SzP 2012), Nyíres (SzP 2012), Tukó-hegy (SzP 2012), Varcsó-völgy (SzP 2006); Jákfalva: Kazai-oldal (SzP 2012); Kurityán: Ormos-hegy (SzP 2006); Ormosbánya: Kopasz-tető (SzP 2021); Szuhafő: Gerenda (SzP 2016), Kerékkötő (SzP 2011), Pető-háza (SzP 2012), Virág-domb (SzP 2015); Trizs: Páris-völgy (SzP 2011); Zádorfalva: Bakó (SzP 2014), Cseres alja (SzP 2014); Zubogy: Doma alja (SzP 2014). Üde erdőkben, égerligetekben, telepített fenyvesekben fordul elő, a területen gyakori. [7588.4], [7589.3], [7688.2], [7689.1], [7689.3], [7689.4].

124. Castanea sativa Mill. - Lit.: Flóratérképezési adat [1]: Felsőnyárád (Anonym 2005). Ined.: Felsőnyárád: Mestergaz (SzP 1999), Őr-hegy (SzP 2003); Kurityán: Gyümölcsös-oldal (SzP 2003); Ragály: Gerenda-oldal (SzP 2008), Ortvány-kert (BG 2015); Trizs: Akasztó-bérc (SzP 2008). Gyümölcsösökben, telepítve, mindenütt csak néhány fáját találtuk. [!7589.3], [7689.4].

**137. Celtis occidentalis L. - Ined.: Kurityán: Szőlő-oldal (BG 2021). Bokorsávban, telepítve. [!7689.4].

139. Morus alba L. - Lit.: Flóratérképezési adatok [1]: Jákfalva (Malatinszky Ákos és Penksza Károly 2003); Szuhafő (Virók Viktor 2004); Gömörszőlős (G. Farkas Tünde 2003). Ined.: Felsőnyárád: Szuha alja (BG 2020); Kurityán: Susa-tető (SzP 2006). Korábbi termesztésekből kivadulva szubspontán egyedek. [!7689.4].

151. Thesium ramosum Hayne. - Lit.: Flóratérképezési adat [1]: Felsőnyárád (Anonym 2005). Ined.: Felsőkelecsény: Aradvány (BG 2021); Felsőnyárád: Mestergaz (BG 2021), Ôrhegy (BG 2021); Kurityán: Malom-mező (BG 2021); Rudolftelep: Cseres-dűlő (BG 2021). Száraz gyepekben. [7689.2], [7689.4], [!7790.1].

156. Viscum album L. - Lit.: Flóratérképezési adatok [1]: Gömörszőlős; Kelemér (G. Farkas Tünde 2003). Ined.: Alsószuha: Bakócz (SzP 2015), Belterület (SzP 2021), Jegenye-völgy (SzP 2015), Szuha (SzP 2021); Dövény: Akácos (SzP 2010), Háromszög-dűlő (SzP 2010), Proletár-földek (SzP 2007), Varcsó-völgy (SzP 2007); Felsőnyárád: Egyház megi dúlő (SzP 2012); Jákfalva: Kender-földek (SzP 2005), Süveges alja (SzP 2021); Kurityán: Belterület (SzP 2016); Ragály: Barom-szer (SzP 2007), Belterület (SzP 2006), Csörgős-patak falu alatti szakasz (SzP 2021), Isten harasztja (SzP 2007); Szuhakálló: Nyomás (SzP 2012); Trizs: Csörgős-lapos (SzP 2010), Diós-oldal (SzP 2013); Zádorfalva: Berek eleje (SzP 2006); Zubogy: Belterület (SzP 2017). Főleg nyár- és füzfajokon találtuk, mindenütt a subsp. album. [!7589.3], [7688.2], [!7689.1], [!7689.3], [!7689.4], [!7789.2].

175. Fallopia $\times$ bohemica (Chrtek et Chrtkova) J. P. Bailey - Lit.: Flóratérképezési adat [1]: Rudabánya (Virók Viktor és Matus Gábor 2004). Ined.: Alsószuha: Belterület (SzP 2006); Szuha (SzP 2006); Felsőkelecsény: Belterület (SzP 2012), Csörgős-patak (SzP 2012); Felsőnyárád: Belterület (SzP 2012); Izsófalva: Belterület (SzP 2012), Kavicsos (SzP 2012), Mogyoróska (SzP 2012), Szuha (SzP 2006); Kurityán: Belterület (SzP 2006), Hársas-erdő (SzP 2006), Hencel-szög (SzP 2012), Szuha (SzP 2006); Múcsony: Meleg-oldal (SzP 2012); Ormosbánya: Belterület (SzP 2012); Ragály: Belterület (SzP 2012), Csörgős-patak (SzP 2006); Rudabánya: Belterület (SzP 2012), Rudabányai-völgy (SzP 2012); Rudolftelep: Bányatelep (SzP 2012), Belterület (SzP 2012), Mák-völgy (SzP 2012); Szuhafő: Belterület (SzP 2012); Szuhakálló: Hosszú-horvát (SzP 2012); Trizs: Belterület (SzP 2012), Csörgős-lapos (SzP 2006), Csörgős-patak (SzP 2006); Zádorfalva: Belterület (SzP 2012), Szuha-völgy (SzP 2012); Zubogy: Belterület (SzP 2006), Meskó-rét (SzP 2012). Sajó-völgy: Múcsony: Belterület (SzP 2012), Szuha (SzP 2006); Szuhakálló: Belterület (SzP 2006). Vizek szegélyein, ruderális gyomtársulásokban gyakori, erősen terjed. [!7588.4], [!7589.3], [!7688.2], [!7689.1], [7689.2], [!7689.3], [!7689.4], [!7690.3], [!7789.2], [!7790.1].

193. Rumex palustris Sm. - Lit.: Gömörszőlős (MoLNÁR et al. 2018). Ined.: Felsőnyárád: Kelecsényi-úton-felüli-dűlő (BG 2021); Kurityán: Vaskapu (BG 2021), Vaskapui-mocsár (BG 2021). Nedves gyomtársulásokban. [!7689.4]. 
197. Rumex confertus Willd. - Lit.: Flóratérképezési adat [1]: Felsőnyárád (Anonym 2005). Ined.: Dövény: Belterület (SzP 2006); Felsőnyárád: Csörgős-patak (BG 2021), Holdas (BG 2021), Jákfalvi-dúlő (BG 2021), Pincék (BG 2021), Szuha alja (BG 2021); Izsófalva: Cseres dűlő (BG 2021); Kurityán: Belső-szög (BG 2021), Szuha (BG 2021); Ragály: Határnál (BG 2020); Zubogy: Borsó-szer (BG 2021). Nedves réteken. [!7689.1], [!7689.2], [!7689.3], [7689.4], [!7790.1].

198. Rumex conglomeratus Murray - Lit.: Putnok (MoLNÁR et al. 2018). Ined.: Kurityán: Fekete-völgy (BG 2021), Szuha (BG 2021). Nedves gyomtársulásban, illetve zátonyon. [!7689.4].

201. Rumex stenophyllus Ledeb. - Lit.: Flóratérképezési adat [1]: Felsőnyárád (Anonym 2005). Ined.: Jákfalva: Alsó-rét (BG 2020); Kurityán: Fekete-völgy (BG 2021), Vaskapuimocsár (BG 2021); Múcsony: Cseres-dűlő (BG 2021); Zubogy: Borsó-szer (BG 2021), Tanya alja (BG 2021). Mocsárréten, nedves gyomtársulásokban. [!7689.1], [!7689.2], [!7689.3], [7689.4], [!7790.1].

217. Chenopodium glaucum L. - Lit.: Gömörszőlős (MolnáR et al. 2018). Ined.: Dövény: Belterület (SzP 2005). Út melletti gyomtársulásban. [!7689.3].

226. Chenopodium opulifolium Schrad. - Herb.: Szuhafő: Virág-domb (Virók 2004, DE). Lit.: Flóratérképezési adat [1]: Szuhafő (Virók Viktor 2004). Ined.: Dövény: Belterület (SzP 2005). Gyomtársulásban. [!7689.3].

238. Atriplex sagittata Borkh. - Lit.: Flóratérképezési adat [1]: Szuhafő (Virók Viktor 2004). Ined.: Felsőkelecsény: Száraz-rét (BG 2021); Felsőnyárád: Fekete-völgyi bánya (SzP 2007), Mestergaz (BG 2021); Izsófalva: Alsó-rét (SzP 2005); Kurityán: Fekete-völgy (BG 2020), Kurityántelepi-bányató (SzP 2006), Szuha (SzP 2006); Ormosbánya: Gyilkos-tó (SzP 2006), Kavicsos - Ormos-patak (SzP 2006); Zádorfalva: Szuha-völgy (SzP 2007). Sajó-völgy: Múcsony: Ragályi-szög (SzP 2006). Gyomtársulásokban. [!7688.2], [7689.2], [!7689.4], [7789.2], [!7790.1].

255. Salsola kali L. - Lit.: Sajó-völgy: Sajószentpéter (VIRÓK et al. 2004); Putnok (MolNÁR et al. 2018). Flóratérképezési adatok [1]: Zubogy (Malatinszky Ákos és Penksza Károly 2003); Kelemér (G. Farkas Tünde 2004). Ined.: Rudolftelep: Felső-rét, 1 tő (SzP 2007). Homokbánya gyomnövényzetében találtuk. [!7690.3].

264. Amaranthus blitum L. - Lit.: Gömörszőlős (MolnáR et al. 2018). Ined.: Izsófalva: Belterület (SzP 2006). Kertben. [!7689.4].

*274. Phytolacca esculenta van Houtte - Herb.: Bódva-völgy: Perkupa (Virók 2016, DE). Lit.: Sajó-völgy: Dubicsány (SCHMOTZER 2019), Putnok (KIRÁLY \& KIRÁLY 2018). Ined.: Dubicsány: Kedves-hegy (BG 2020). Gyomtársulásban. [7788.2].

300. Cerastium dubium (Bastard) Guépin - Lit.: Serényfalva (PENKSZA \& MALATINSZKY 2001). Ined.: Dövény: Alsó-rét (SzP 2021), Kötél-föld (SzP 2021); Felsőkelecsény: Aradvány (BG 2021), Felső-rét (BG 2021); Felsőnyárád: Gyökér-kúti-dúlő (SzP 2021), Kelecsényi-útonaluli-dűlő (BG 2021), Kelecsényi-úton-felüli-dűlő (BG 2021), Szuha alja (BG 2021); Kurityán: Malom-mező (BG 2021), Vaskapu (BG 2021). Nedves réteken, szántókon. [!7689.2], [!7689.3], [!7689.4].

315. Sagina procumbens L. - Lit.: Putnok (MolnáR et al. 2018). Ined.: Felsőnyárád: Belterület (BG 2021). Kövek, járdák repedéseiben. [!7689.4].

323. Scleranthus annuus L. - Herb.: Rudabánya (Soó 1936, DE); Rudabányai-hegység: Rudabánya (Virók 2001, DE). Lit.: Flóratérképezési adat [1]: Jákfalva (Malatinszky Ákos és Penksza Károly 2003). Ined.: Dövény: Alsó-rét (SzP 2007). Szántón. [7689.3].

329. Spergula arvensis L. - Lit.: Gömörszőlős (FARKAS 2010). Ined.: Ragály: Ortvány-kert (SzP 2006). Kalászos vetésben. [7589.3]. 
332. Spergularia rubra (L.) J. Presl et C. Presl - Lit.: Sajó-völgy: Sajókaza (HASZoNITS et al. 2021). Flóratérképezési adatok [1]: Jákfalva; Zubogy (Malatinszky Ákos és Penksza Károly 2003). Ined.: Dövény: Háromszög-dűlő (SzP 2008). Szántón. [7689.3].

335. Lychnis coronaria (L.) Desr. - Lit.: Sajógalgóc: Nagy-pallag (CSIKY et al. 2017). Ined.: Rudabánya: Agyagos-oldal (BG 2017), Fekete-parlag (BG 2017). Erdőszegélyben, felhagyott gyümölcsös gyepében. [!7689.2].

337. Agrostemma githago L. - Lit.: Gömörszőlős: Csató-bérc alja (PENKSZA et al. 1999/2000, MALATINSZKY 2004); Dövény: Alsó-rét; Gömörszőlős (MaLATinszkY 2007), Gömörszőlős: Cuda (MaLATinszky 2008). Ined.: Dövény: Alsó-rét (SzP 2001), Kötél-föld (SzP 2016); Felsőkelecsény: Nyárádi-dúlő (SzP 2001); Felsőnyárád: Szuha alja (SzP 2006); Gömörszőlős: Pozsok-völgy (SzP 1996); Jákfalva: Kender-földek (SzP 2009), Köteles alja (SzP 2001); Kurityán: Temető alj, több száz tő (SzP 2014); Ragály: Barom-szer (SzP 2008), Ortvány-kert (SzP 2006); Szuhakálló: Hosszú-horvát (SzP 2006); Trizs: Parcellás (SzP 2009); Zádorfalva: Nagy-szőlő alja (SzP 2009). Szántóföldi kalászos kultúrákban, legtöbbször csak néhány tucat töves állományait találtuk. [!7588.4], [!7589.3], [7688.2], [!7689.2], [7689.3], [!7689.4], [!7789.2].

370. Dianthus deltoides L. - Herb.: Rudabánya (Soó 1936, DE). Lit.: Rudabánya (Soó et al. 1943), Alsószuha: Bakóc-völgy; Imola: Avas-oldal; Ragály mellett; Trizs mellett; Zádorfalva: Mocsolyás-völgy (PenksZa \& MaLATinszky 2001), Alsószuha: Jegenye-völgy; Dövény: Akácos, Alsó-rét, Felső-rét, Háromszög-dűlő, Kötél-föld, Varcsó-völgy; Felsőkelecsény: Őrfatető, Rózsás-tető; Imola: Avas-oldal, Bakbán, Leléte-völgy, Temető mellett; Jákfalva: Borcsog-föld, a falu és a Szuha patak közötti terület (Falu-rét), Nagy-Varcsó-völgy, Németh-tag; Sajókaza; Szuhafő: Centu-hegy; Zádorfalva: Iván-tető (MALATINSZKY 2007), Alsószuha: Lengyel-oldal (MalaTinszky 2008). Ined.: Alsószuha: Bakóc-oldal (SzP 2010), Bakócz (SzP 2009), Büdös-kút-oldal (SzP 2013), Dobos-tető (SzP 2013), Feneketlen (SzP 2009), Gyámol-völgy (SzP 2004), Hegyes-hegy (SzP 2010), Jegenye-völgy (SzP 2000), Kis-kánya-fő (SzP 2009), Nádas-rét (SzP 2000), Ritka-dúlő (SzP 2021), Ritka-oldal (SzP 2006), Szarvasoldal (SzP 2009), Virág-oldal (SzP 2021); Dövény: Kavacs-domb (SzP 2012), Kerek-föld (SzP 2012), Nyíres (SzP 2012), Proletár-földek (SzP 2009), Varcsó-völgy (SzP 2007); Felsőkelecsény: Aradvány (BG 2021), Galagonyás (BG 2010), Kelecsényi-Nagy-hegy (SzP 1996); Felsőnyárád: Belterület (BG 2019); Kazai-dúlő (SzP 2006), Kelecsényi-úton-aluli-dúlő (BG 2017), Kővágói-rét (BG 2010), Mestergaz (SzP 1994), Nagy-erdő (SzP 1994), Németh-tag (SzP 2008), Ốr-hegy (BG 2006), Válós-út alja (SzP 1994); Imola: Puszta-szőlő (SzP 1996); Izsófalva: Cseres-dúlő́ (SzP 2006), Kopasz-tető (SzP 2012), Koplaló (SzP 2012), Meszes (SzP 2012), Sürü-tető (SzP 2012); Jákfalva: Falu-rét (SzP 2019), Gyomor-oldal (SzP 2011), Gyökér-kúti-rét (SzP 1994), Jákvarcsó (SzP 2009), Kazai-oldal (BG 2010), Nagy-föld-dűlő (SzP 2006), Nyírjes (SzP 1995), Süveges-oldal (BG 2010), Tövises-völgy (SzP 2001); Kurityán: Koritó (SzP 1994), Szőlő-oldal (SzP 1994); Ragály: Csikó-rét (SzP 2010), Csornok (SzP 1995), Dobrosó-oldal (SzP 2007), Nagy-föld (SzP 2007), Ortvány-kert (SzP 1995); Rudabánya: Fekete-parlag (BG 2017); Rudolftelep: Cseres-dűlő (BG 2017); Szuhafő: Kerékkötő (SzP 2013), Kis kútnál (SzP 2012), Pálykás (SzP 2012), Pető-háza (SzP 2011), Pető-háziszőlő (SzP 2000), Péter-völgy (SzP 2006), Puha-völgy (SzP 2006), Szuha-völgy (SzP 2017), Tubóka (SzP 2017), Virág-domb (SzP 1996); Trizs: Csörgős-patak völgye (SzP 2009), Eresztvény-tető (SzP 2010), Forrás-völgy (SzP 2021), Pallagok (SzP 2010), Páris-völgy (SzP 2008), Rozsnyói-oldal (SzP 2010); Zádorfalva: Bors-völgy (SzP 2021), Bütykös alja (SzP 2014), Cseres-völgy (SzP 2006), Kis-erdő-tető (SzP 2012), Latrány (SzP 2009), Latrányvölgy-fő (SzP 2016), Petrecz (SzP 2016), Pót-haraszt (SzP 2016), Rókalyuk (SzP 2010), Varjas-part (SzP 2021); Zubogy: Dobrosó-völgy (BG 2020), Kavacsos-oldal (SzP 2005), Krizsán-bérc (SzP 1996), Suba-oldal (BG 2017), Zúgó-völgy (SzP 1996). A faj a Putnokidombságban nem ritka, sovány és félszáraz gyepekben, néhol sok százas állományokat al- 
kot (megjelenése általában foltszerű, gyakran földutak, keréknyomok mellé koncentrálódik). [7588.4], [7589.3], [7688.2], [7689.1], [7689.2], [7689.3], [7689.4], [7690.3], [!7790.1].

376. Dianthus collinus Waldst. et Kit. - Herb.: Sajó-völgy: Putnok (Zólyomi 1927, BP). Lit.: Putnok: Hegyes-tető; Sajókaza: Ráró-hegy, Szár-hegy (PEnKsZa \& MALATinszkY 2001, MALATINSZKY 2004, MALATINSZKY \& ÁDÁM 2012); Sajógalgóc (MALATinsZKY 2007). Ined.: Felsőnyárád: Aradvány (BG 2020); Izsófalva: Alsó-rét (SzP 2005), Cseres-dủlő, több száz tő (SzP 2000), Gede-tető (SzP 2006); Kurityán: Kurityán-tető (SzP 2000), Temető alj (SzP 2006); Múcsony: Cseres-szőlő, több száz tő (SzP 2008); Rudolftelep: Cseres-szőlő (BG 2017); Szuhakálló: Meleg-oldal (BG 2017), Nyomás (SzP 2000). Száraz és félszáraz gyepekben. [7689.4], [7789.2], [!7790.1].

**379. Nymphaea rubra Roxb. - Ined.: Izsófalva: Alsó-réti-bányatavak (SzP 2014). Telepítve. [!7789.2]. A tavak rekultivációja után eltűnt.

384. Ceratophyllum submersum L. - Lit.: Serényfalva (MALATINSZKY 2007). Ined.: Izsófalva: Meszes (SzP 2021); Jákfalva: Gyökér-kúti mocsár (SzP 2011); Ragály: Csornok (SzP 2021). Hínárnövényzetben jelentős állományokat alkot. [!7589.3], [!7689.4].

385. Ceratophyllum demersum L. - Herb.: Sajó-völgy: Múcsony (Virók 2003, DE). Lit.: Sajóvölgy: Sajóvelezd (HASzoniTs et al. 2021). Flóratérképezési adat [1]: Felsőnyárád (Anonym 2005). Ined.: Izsófalva: Alsó-réti-bányatavak (SzP 2006), Kavicsosi-bányató (SzP 2006), Mák-völgyi-bánya (SzP 2021), Szuha (SzP 1999); Kurityán: Kurityántelepi-bányató (SzP 2006), Szuha (SzP 1999); Ormosbánya: Gyilkos-tó (SzP 2021), Máris-rét (SzP 2021). Hínártársulásokban. [7689.4], [7690.3], [!7789.2].

391. Nigella arvensis L. - Lit.: Gömörszőlős; Izsófalva: Mogyoróska (VIRóK et al. 2004); Sajókaza (HASzonITS et al. 2021). Ined.: Felsőnyárád: Mestergaz (SzP 2004), Őr-hegy (BG 2019); Izsófalva: Gede-tető (SzP 2008), Koplaló (SzP 2004); Kurityán: Susa-tető (BG 2014); Trizs: Eresztvény-tető (SzP 2010). Parlagokon, száraz gyepekben, felhagyott szőlőkben. [!7588.4], [7689.4], [!7789.2].

395. Actaea spicata L. - Herb.: Putnok (Zólyomi 1927, BP). Lit.: Kelemér; Zádorfalva: Ivántető (VIRóK et al. 2010). Ined.: Alsószuha: Bakóc-völgy (SzP 2008), Kánya-fő (SzP 2019); Szuhafő: Kerékkötő (SzP 2013), Pálykás (SzP 2017), Pető-háza (SzP 2010), Pető-házi-szőlő (SzP 2012); Zádorfalva: Kis-völgy (SzP 2014), Latrány (SzP 2014), Nagy-völgy (SzP 2021), Varjas-part (SzP 2010). Üde erdőkben, szurdokszerű völgyekben találtuk. [!7588.4], [7688.2], [7689.1].

404. Consolida orientalis (J. Gay) Schrödinger - Lit.: Bódva-völgy: Perkupa (VIRóK et al. 2016). Flóratérképezési adat [1]: Felsőnyárád (Anonym 2005). Ined.: Felsőnyárád: Kelecsényi-úton-felüli-dúlő (SzP 2001); Ragály: Ortvány-kert (SzP 2008); Szuhakálló: Hosszúhorvát (SzP 2006); Zubogy: Dövény-szögi-dűlő (SzP 2006). Vetésekben. [!7589.3], [!7689.1], [7689.4], [!7789.2].

406. Aquilegia vulgaris L. - Lit.: Szuhafő: Tőkés (Pincék alja) (VIRóK et al. 2004); Kelemér; Szuhafő: belterület (MaLaTinszKY 2007). Ined.: Dövény: Kötél-föld (SzP 2021); Szuhafö: Centu-hegy (SzP 2014), Pető-házi-szőlő (SzP 2009), Puha-völgy (SzP 2021). Száraz réteken, felhagyott szőlőben kivadulva fordul elő, állományai nem őshonosak. [7588.4], [7688.2], [!7689.3].

409. Anemone sylvestris L. - Lit.: Gömörszőlős (PENKSZA \& MALATINSZKY 2001); Ragály: Gerenda-oldal; Zádorfalva: Iván-tető, Ragyás-szőlő (MALATINSZKY 2007); Kelemér (FARKAS 2010); Gömörszőlős: Temető (MoLNÁR V. \& LöKI 2018). Ined.: Alsószuha: Feneketlen (SzP 2015); Szuhafő: Centu-hegy (SzP 2017), Pető-házi-szőlő, néhány tő (SzP 2001), Temető (SzP 2017); Zádorfalva: Bakó, két kis folt (SzP 2008), Iván-tető (SzP 1995), Varjas-part (SzP 1995). Sztyepréteken, állományai visszaszorulóban vannak. [!7588.4], [7688.2], [!7689.1]. 
414. Pulsatilla grandis Wender. - Herb.: Putnok (Zólyomi 1926, BP). Lit.: Gömörszőlős: Kasza-hegy, Szőlő-hegy (Penksza \& MALATinszKY 2001); Gömörszőlős: Szőlőhegy, Kaszahegy; Serényfalva és Kelemér közötti dombokon (MALATıNSZKY 2004); Kelemér; Putnok; Zádorfalva: Iván-tető, Latrány, Nagy-Szőlő-tető, Ragyás-szőlő (MALATıNSZKY 2007); Gömörszőlős; Kelemér (FARKAS 2010); Gömörszőlős: Temető (MoLNÁR V. \& LÖKI 2018). Ined.: Alsószuha: Ritka-dűlő, 2 tő (SzP 2009); Szuhafő: Pető-házi-szőlő, 10 tő (SzP 2017); Zádorfalva: Bakó, 250 tő (SzP 2008), Bütykös alja, 100 tő (SzP 2008), Cseres alja, 10 tő (SzP 2010), Cseres-völgy, 250 tő (SzP 2010), Kis-völgy, 22 tő (SzP 2016), Latrány-völgy, 100 tő (SzP 2010), Rakottyás-tető, 2 tő (SzP 2009), Varjas-part, 250 tő (SzP 1998). A faj a Putnokidombságban nem gyakori, néhány élőhelyéről (Alsószuha: Ritka-dűlő, Zádorfalva: Bakó, Rakottyás-tető) az utóbbi években eltűnt, lejtősztyepeken és erdőszéleken fordul elő. [7588.4], [7688.2], [!7689.1].

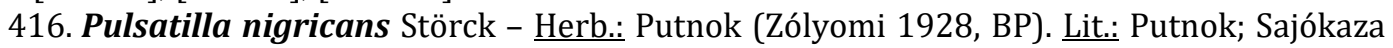
(PENKSZA \& MALATinszKY 2001). Ined.: Alsószuha: Feneketlen, 82 tő (SzP 2006); Trizs: Eresztvény-tető, 5 tő (SzP 2021), Forrás-völgy, 22 tő (SzP 2021). Lejtősztyepeken és erdőszéleken kis állományait találtuk. Az Alsószuháról (MALATıNSZKY 2007) említett P. pratensis subsp. zimmermannii-t nem találtuk. [!7588.4], [7689.1].

418. Clematis integrifolia L. - Lit.: Sajókaza (PENKSZA \& MALATINSZKY 2001). Ined.: Izsófalva: Alsó-rét (SzP 2003); Múcsony: Cseres-szőlő (SzP 2000), Meleg-oldal (BG 2016); Rudolftelep: Cseres-szőlő (BG 2017). A Putnoki-dombságban ritka, a terület déli mocsárrétjein és félszáraz gyepjeiben került elő. [!7690.3], [7789.2], [!7790.1].

442. Ranunculus flammula L. - Herb.: Szuhafő (Vojtkó 2000, BP). Lit.: Flóratérképezési adat [1]: Gömörszőlős (G. Farkas Tünde 2004). Ined.: Izsófalva: Kavicsos (SzP 2021). Árokban. [!7689.4],

448. Ranunculus arvensis L. - Lit.: Felsőkelecsény: Bozsdár; Gömörszőlős; Rudabánya: Hatút-oldal; Zádorfalva: Szuha-völgy (VIRók et al. 2010). Ined.: Dövény: Alsó-rét (SzP 2021); Ormosbánya: Kavicsos (SzP 1996); Ragály: Ortvány-kert (SzP 2006); Zubogy: Borsó-szer (SzP 2005). Szántókon. [!7589.3], [7689.2], [!7689.3], [7689.4].

454. Ranunculus lanuginosus L. - Herb.: Putnok (Zólyomi 1928, BP). Lit.: Gömörszőlős (MolnÁr et al. 2016). Ined.: Szuhafő: Pető-háza (SzP 2008). Gyertyános-tölgyesben. [7688.2].

*459. Myosurus minimus L. - Herb.: Bódva-völgy: Bódvaszilas (Farkas R. 2016, DE). Lit.: Bódva-völgy: Szögliget (VIRóK et al. 2016). Ined.: Alsószuha: Alsó-rét (SzP 2021); Dövény: Alsó-rét (SzP 2021); Felsőkelecsény: Felső-rét (BG 2021); Felsőnyárád: Gyökér-kúti-dűlő (SzP 2021), Kelecsényi-úton-aluli-dűlő (BG 2021); Jákfalva: Gyökér-kúti-rét (SzP 2021), Köteles alja (SzP 2021). Nedves réteken és főleg előző évi kukoricavetésekben. [!7689.1], [!7689.2], [!7689.3], [!7689.4].

*460. Thalictrum aquilegiifolium L. - Lit.: Aggteleki Fedett-karszt: Aggtelek (SOMLYAY \& LŐKÖS 1999, VIRóK et al. 2016). Ined.: Felsőnyárád: Mestergaz, a megtaláláskor 1 tő, a későbbi években a közelben megjelent még 2-3 tő (BG 2012). Erdőszegélyen, cseres-tölgyes tatárjuharos szegélyben, a hegygerinc észak felé hajló részén. [!7689.4].

*464. Thalictrum simplex L. subsp. galioides (DC.) Korsh. - Lit.: Aggteleki Fedett-karszt: Aggtelek (VIRóK et al. 2004, VIRóK et al. 2016); Bódva-völgy: Perkupa; Galyaság: Szőlősardó, Teresztenye, Varbóc; Rudabányai-hegység: Felsőtelekes, Szendrő (VIRóK et al. 2016). Ined.: Felsőkelecsény: Nagy-hegyi-szőlő (BG 2020). Száraz gyepben. [!7689.2].

470. Berberis vulgaris L. - Lit.: Flóratérképezési adatok [1]: Jákfalva; Zubogy (Malatinszky Ákos és Penksza Károly 2003). Ined.: Kurityán: Szőlő-oldal (BG 2020). Bokorsávban, valószínűleg telepítve. [!7689.4].

488. Corydalis solida L. - Lit.: Flóratérképezési adatok [1]: Imola (Vojtkó András 2001); Rudabánya (Matus Gábor és Virók Viktor 2001). Ined.: Sajókaza: Nagy-erdő, néhány tő (BG 
2017). Cseres-tölgyesben. A lelőhely egy az 1960-as években felhagyott, mára beerdősödött legelőerdő területén, annak egykori szegélyéhez közeli részén helyezkedik el. A terület egészén számos 150-200 éves hagyásfa található. A populáció nagyságát, annak pontos kiterjedését nem vizsgáltuk. [!7689.3].

*500. Sisymbrium loeselii L. - Herb.: Aggteleki Fedett-karszt: Aggtelek (Virók 2009, DE); Rudabányai-hegység: Rudabánya (Virók 2016, DE); Sajó-völgy: Múcsony (Virók 2009, DE). Lit.: Sajó-völgy: Putnok (HASzonits et al. 2021). Ined.: Felsőkelecsény: Száraz-rét (BG 2021). Száraz gyepben. [!7689.2].

508. Erysimum cheiranthoides L. - Herb.: Szuhafő: Virág-domb (Virók 2004, DE); Zádorfalva (Sramkó 2008, DE). Lit.: Flóratérképezési adat [1]: Szuhafő (Virók Viktor 2004). Ined.: Felsőnyárád: Szuha alja (BG 2021). Kukoricaföld szegélyében. [!7689.4].

518. Hesperis sylvestris Crantz - Herb.: Felsőnyárád (Takács 2014, DE). Lit.: Felsőnyárád: Mestergaz (TAKÁCS et al. 2016); Kelemér (MolnáR et al. 2018); Sajógalgóc (MolnÁR et al. 2019). Ined.: Felsőkelecsény: Aradvány-erdő (BG 2021); Felsőnyárád: Kis-erdő (BG 2020); Kurityán: Koritó (SzP 2006). A Putnoki-dombságban ritka, cserjés erdőszéleken találtuk. [7689.2], [7689.4].

536. Cardamine glanduligera 0. Schwarz - Lit.: Alsószuha: Bakóc-völgy (PENKSzA et al. 1999/2000, Penksza \& Malatinszky 2001). Ined.: Alsószuha: Putnoki-oldal (SzP 2017). A Bakóc-pataktól légvonalban kb. 300 m-re a domboldali gyertyános-tölgyesben, a völgyi állománytól elszigetelődve 4 folt. [!7688.2].

547. Arabis glabra L. Bernh. - Lit.: Flóratérképezési adat [1]: Szuhafő (Virók Viktor 2004). Ined.: Felsőkelecsény: Aradvány (BG 2021), Nagy-hegyi-szőlő (BG 2021); Felsőnyárád: Mestergaz (BG 2021), Őr-hegy (BG 2019); Kurityán: Ormos-hegy (SzP 2008), Susa-tető (SzP 2008). Cserjésekben. [!7689.2], [!7689.4].

554. Lunaria annua L. - Lit.: Gömörszőlős (MolnáR et al. 2016). Ined.: Dövény: Szuha (SzP 2007), Varcsó-patak (SzP 2008). Patakok mentén, kivadulva. [!7689.3].

*574. Camelina microcarpa Andrz. ex DC. - Herb.: Aggteleki Fedett-karszt: Aggtelek (Virók 2001 DE). Lit.: Galyaság: Varbóc (VIRóK et al. 2016); Sajó-völgy: Serényfalva (HASzoNITS et al. 2021). Ined.: Felsőnyárád: Mestergaz (BG 2021), Őr-hegy (BG 2019); Kurityán: Susa-tető (BG 2021). Felnyíló, nyílt gyepekben, löszszerű, csupasz talajfelszínen. [!7689.4].

578. Neslia paniculata (L.) Desv. - Lit.: Gömörszőlős (PENKSZA et al. 1999/2000, SOMLYAY 2000, MalatinszKY 2004); Alsószuha: Virágos-oldal (Hegyes-hegy) (MolnÁr et al. 2019). Ined.: Ragály: Ortvány-kert (SzP 2006). Kalászos vetésben. [!7589.3].

645. Saxifraga bulbifera L. - Herb.: Dövény (Budai, BP). Lit.: Dövény; Felsőnyárád; Kurityán; Sajókaza (BudAI 1914). Ined.: Alsószuha: Ritka-oldal (SzP 2011); Szuhafő: Pető-háza (SzP 2008). Száraz gyepben, erdőszegélyben. [!7688.2], [!7689.1].

650. Chrysosplenium alternifolium L. - Lit.: Flóratérképezési adatok [1]: Szuhafő (Virók Viktor 2004); Gömörszőlős; Kelemér (G. Farkas Tünde 2004). Ined.: Alsószuha: Bakócvölgy (SzP 2001); Szuhafő: Gerenda (SzP 2014). Égerligetben, üde lomberdőben. [7588.4], [!7689.1].

723. Potentilla supina L. - Lit.: Gömörszőlős (MoLNÁR et al. 2016). Ined.: Felsőnyárád: Jákfalvi-dűlő (BG 2021). Kiszáradó belvízfolton. [!7689.4].

*726.1. Potentilla collina Wibel - Herb.: Aggteleki Fedett-karszt: Aggtelek (Virók 2005, DE). Ined.: Dövény: Varcsó (SzP 2021); Felsőkelecsény: Borsó-szer (BG 2021); Felsőnyárád: Kelecsényi-úton-aluli-dűlő (BG 2021); Jákfalva: Köteles alja (BG 2021); Kurityán: Malommező (BG 2021), Szőlő-oldal (BG 2021); Ragály: Pénzvermek (SzP 2021). Száraz gyepekben. [!7689.1], [!7689.2], [!7689.3], [!7689.4].

817. Padus avium Mill. - Lit.: Szuhafö: Szuha-völgy (PENKSZA \& Somlyay 1999); Serényfalva (VIRóK et al. 2004). Ined.: Felsőnyárád: Csörgős-patak (BG 2019); Jákfalva: Köteles (SzP 2015). Égerligetekben. [!7689.3], [!7689.4]. 
836. Sarothamnus scoparius (L.) Wimm. ex W. D. J. Koch - Lit.: Sajókaza (HASzoniTs et al. 2021). Flóratérképezési adatok [1]: Felsőnyárád (Anonym 2005); Jákfalva (Malatinszky Ákos és Penksza Károly 2003). Ined.: Alsószuha: Virág-oldal (SzP 2021); Dövény: Akácos (SzP 2010), Háromszög-dűlő (SzP 2010), Kerek-föld (SzP 2021), Pencs-tető (BG 2016), Proletár-földek (SzP 2007); Jákfalva: Nyírjes (SzP 2012); Zubogy: Krizsán-bérc (BG 2012). Ültetve, elvadul. Dövény környékén a Varcsó korábban ültetett nagy állományából terjed, máshol csak 1-2 tövét találtuk. [!7689.1], [7689.3].

837. Corothamnus procumbens (Waldst. et Kit.) C. Presl. - Lit.: Flóratérképezési adatok [1]: Imola (Vojtkó András 2001); Rudabánya (Virók Viktor és Matus Gábor 2004). Ined.: Szuhafő: Pető-házi-szőlő (SzP 2006). Sztyepréten. [!7688.2].

841. Chamaecytisus albus (Hacq.) Rothm. - Herb.: Putnok (Zólyomi 1926, BP); Szuhafő (Sramkó 2008, DE). Lit.: Putnok (HuLJÁK 1926); Gömörszőlős: Pozsok; Putnok: Hegyes-tető; Sajókaza: Ráró-hegy, Szár-hegy; Trizs mellett; Zádorfalva: Rakottyás-tető (PENKSZA \& MALATINSZKY 2001); Felsőnyárád: Kővágó (Mestergaz); Gömörszőlős; Kelemér; Zádorfalva: Iván-tető, Latrány, Nagy-Szőlő-tető, Ragyás-szőlő (MALATINSZKY 2007); Gömörszőlős (FARKAS 2010, MolnÁR et al. 2016); Alsószuha: Virágos-oldal (Hegyes-hegy); Sajókaza (MolnáR et al. 2019). Ined.: Alsószuha: Feneketlen (SzP 2007), Vad-répás (SzP 2018); Felsőkelecsény: Aradvány-erdő (BG 2020), Nagy-hegyi-szőlő (SzP 2009), Száraz-rét (SzP 2008); Felsőnyárád: Kővágó alja (SzP 1994), Mestergaz (SzP 1994), Válós-út alja (SzP 1994); Izsófalva: Kavicsos (SzP 1994); Kurityán: Gyümölcsös-oldal (SzP 2006), Koritó (SzP 1994), Kurityán-tető (BG 2012), Malom-mező (BG 2013), Susa-tető (SzP 2008), Szőlő-oldal (SzP 1994); Szuhafő: Centu-hegy (SzP 2009), Kis kútnál (SzP 2012), Pető-házi-szőlő (SzP 2000), Pincék alja (SzP 2000), Virág-domb (SzP 1996); Trizs: Comád (SzP 2011), Eresztvény-tető (SzP 2014), Rozsnyói-oldal (SzP 1999); Zádorfalva: Almás (SzP 2012), Arany-kúti-oldal (SzP 2009), Bakó (SzP 2006), Berek eleje (SzP 2005), Bors-völgy (SzP 2021), Bütykös alja (SzP 2009), Bütykös-oldal (SzP 2011), Cseres alja (SzP 1996), Cseres-völgy (SzP 2009), Kisvölgy (SzP 2011), Latrány-völgy (SzP 2006), Nagy-kánya-fő (SzP 2009), Nagy-szőlő (SzP 1998), Nagy-szőlő alja (SzP 1997), Petrecz (SzP 2012), Pót-haraszt (SzP 2012), Ragyásszőlő (SzP 2002), Rakottyás-tető (SzP 1995), Rakottyás-völgy (SzP 2011), Szellő-tető (SzP 1995), Templom-oldal (SzP 2009), Varjas-part (SzP 1996). A faj a Putnoki-dombságban nem ritka, száraz gyepeken, ritkábban erdőszéleken néhány tőtől több ezer tőig terjedő állományokat alkot. [7588.4], [7688.2], [7689.1], [7689.2], [7689.4].

848. Genista germanica L. - Herb.: Dövény; Kurityán; Sajógalgóc (Budai s.d., BP); Rudabánya (Soó 1936, DE); Trizs (Boros 1953, BP); Kelemér (Gotthárd 1979, MM). Lit.: Dövény; Felsőnyárád; Kurityán; Sajógalgóc; Sajókaza (BuDAI 1914); Rudabánya (Soó et al. 1943); Imola: Avas-oldal; Putnok; Trizs (PEnKSZA \& MALATINSZKY 2001); Alsószuha: Jegenye-völgy; Dövény: Határ-völgy; Szuhafő: Tubóka, Virág-domb (MALATinSzKY 2007); Kelemér (MolNÁR et al. 2016). Ined.: Alsószuha: Feneketlen (SzP 2014), Ritka-dűlő (SzP 2001), Virág-oldal (SzP 2021); Dövény: Háromszög-dűlő (SzP 2021), Varcsó-völgy (SzP 2008); Imola: Ivó-kút (SzP 2021); Putnok: Szőlő-hegy (BG 2018); Szuhafő: Pető-háza (SzP 2009), Pető-házi-szőlő (SzP 2021); Trizs: Forrás-völgy (SzP 2021), Páris-völgy (SzP 2008); Zádorfalva: Iván-tető (SzP 2009), Ragyás-szőlő (SzP 2009). Mészkerülő réteken. [7588.4], [7589.3], [7688.2], [7689.1], [7689.3], [7788.2].

*853. Lupinus polyphyllus Lindl. - Lit.: Aggteleki Fedett-karszt: Aggtelek (VIRóK et al. 2016). Ined.: Rudolftelep: Mák-patak völgye (SzP 2013). Gyomtársulásban elvadulva. [!7690.3]

**858. Robinia viscosa Vent. - Ined.: Izsófalva: Kavicsos (SzP 2021). Egykori meddőhányó területén. [!7689.4].

860. Galega officinalis L. - Lit.: Kelemér és Zádorfalva közötti terület (PENKSZA \& MALATINSZKY 2001); Sajókaza; Serényfalva (MALATinSZKY 2007). Ined.: Felsőkelecsény: Aradvány alja (SzP 2009), Csörgős-patak (BG 2020); Felsőnyárád: Aradvány (BG 2020), Kele- 
csényi-úton-aluli-dűlő (SzP 2006); Izsófalva: Alsó-rét (SzP 2005), Kavicsosi-bányató (SzP 2011), Szuha (SzP 1999); Kurityán: Szuha (SzP 1999); Zubogy: Belterület-Csörgős patak (SzP 2006), Fekete-föld (SzP 2009). Nedves réteken, patakok mellett és azok zátonyain. [!7689.1], [7689.2], [7689.4], [!7789.2].

861. Colutea arborescens L. - Lit.: Sajókaza (PENKSZA \& MALATINSZKY 2001); Sajógalgóc; Sajókaza (MALATinszKY \& ÁDÁM 2012). Ined.: Dubicsány: Gyöngyös-hegy (BG 2017); Sajógalgóc: Nagy-hegy (BG 2017), Padi-földek (BG 2017); Sajókaza: Kurityán-tető (BG 2015), Papszőlők (BG 2014). Száraz tölgyesekben, bokorerdőkben. [7689.4], [7788.2], [7789.1].

903. Vicia grandiflora Scop. - Lit.: Flóratérképezési adat [1]: Felsőnyárád (Anonym 2005). Ined.: Alsószuha: Megye-berek (SzP 2018); Dövény: Háromszög-dűlő (SzP 2021), Kötél-föld (SzP 2015); Felsőnyárád: Aradvány (BG 2020), Belterület (SzP 1996), Fekete-völgy (SzP 1996), Kelecsényi-úton-aluli-dűlő (SzP 1996), Kurityáni-dűlő (SzP 2007), Mestergaz (SzP 1996), Pincék (BG 2020); Izsófalva: Belterület (SzP 1996), Gede-tető (SzP 1996), Kavicsos (SzP 1996), Koplaló (SzP 2021), Mák-patak völgye (SzP 2006), Mogyoróska (SzP 2021), Súrű-tető (SzP 2021); Jákfalva: Gyökér-kúti-rét (SzP 2021), Kazai-oldal (SzP 2021); Kurityán: Belterület (SzP 1996), Fekete-völgy (SzP 2021), Hársas-erdő (SzP 2014), Kazai-oldal (SzP 2006), Koritó (SzP 1996), Kurityáni-bányató (SzP 1996), Malom-mező (SzP 2021), Szőlőoldal (SzP 1996), Temető alj (SzP 2014), Vaskapu (SzP 2006); Ragály: Barom-szer (SzP 2007); Rudolftelep: Gede-oldal (SzP 2021); Szuhakálló: Nyomás (SzP 2014); Trizs: Parcellás (SzP 2009), Páris-völgy (SzP 2008); Zádorfalva: Gyámol (SzP 2006), Szellő-tető (SzP 2021). Szántókon, parlagokon, utak mentén. [!7588.4], [!7589.3], [!7688.2], [!7689.1], [!7689.3], [7689.4], [!7690.3], [!7789.2].

908. Vicia angustifolia L. - Herb.: Rudabánya (Soó 1936, BPU). Lit.: Rudabánya (Soó et al. 1943); Felsőkelecsény (MolnáR et al. 2018). Ined.: Alsószuha: Bakócz (SzP 2005), Kiskánya-fő (SzP 2021); Felsőkelecsény: Aradvány (BG 2021), Felső-rét (BG 2021); Felsőnyárád: Kelecsényi-úton-aluli-dűlő (BG 2021), Kelecsényi-úton-felüli-dúlő (BG 2021), Mestergaz (BG 2021), Őr-hegy (BG 2021), Pincék (BG 2021); Jákfalva: Süveges-oldal (BG 2021); Kurityán: Kazai-oldal (SzP 2006), Ormos-hegy (BG 2021); Múcsony: Cseres-szőlő (BG 2021); Rudabánya: Fekete-parlag (BG 2021), Ravasz-lyuk (BG 2021), Sinai-oldal (BG 2021); Zádorfalva: Szuha-völgy (SzP 2021). Száraz gyepekben, szántókon. [!7688.2], [!7689.1], [7689.2], [!7689.3], [!7689.4], [!7790.1].

911. Lathyrus nissolia L. - Herb.: Rudabánya (Soó 1936, DE); Ormosbánya: Ormos alja (Farkas R. 2001, DE); Kurityán: Belső-szög (Takács 2014, DE). Lit.: Szuhakálló (BudAI 1912); Rudabánya (Soó et al. 1943); Szuhafő: Szuha-völgy; Trizs: Hidegvíz-völgy (SomLYAY \& LőKös 1999); Gömörszőlős (MolnáR et al. 2018). Ined.: Alsószuha: Dobos-tető (SzP 2012), Feneketlen (SzP 2010), Gyámol-völgy (SzP 2020), Hegyes-hegy (SzP 2019), Kánya-fő (SzP 2001), Kis-kánya-fó (SzP 2006), Lác-oldal (SzP 2010), Ritka-dúlő (SzP 2006), Ritka-oldal (SzP 2010); Dövény: Kerek-föld (SzP 2014), Varcsó-völgy (SzP 2012); Felsőkelecsény: Aradvány (BG 2021), Aradvány alja (BG 2021), Felső-rét (BG 2021), Száraz-rét (SzP 2008); Felsőnyárád: Kelecsényi-úton-aluli-dúlő (SzP 2006), Kelecsényi-úton-felüli-dűlő (BG 2021), Mestergaz (SzP 1994), Őr-hegy (BG 2021), Pincék (BG 2020), Vállós-út-alja (SzP 1994); Izsófalva: Gede-tető (SzP 2006), József-oldal (SzP 2021), Kavicsos (SzP 2021), Kopasz-tető (SzP 2006), Koplaló (SzP 2021), Mák-patak völgye (SzP 2007), Meszes SzP 2021), Mogyoróska (SzP 2021); Jákfalva: Gyökér-kúti-rét (SzP 2021), Süveges-oldal (SzP 2016), Tövisesvölgy (SzP 2001); Kurityán: Kazai-oldal (SzP 2006), Malom-mező (BG-SzP 2021), Susa-tető (SzP 1994), Temető alj (SzP 2014); Ormosbánya: Mogyoróska (SzP 2021), Ormos-oldal (SzP 2006); Ragály: Csornok (SzP 1995), Ortvány-kert (SzP 2008); Rudabánya: Agyagosoldal (BG 2021), Bodon (BG 2021), Fekete-parlag (BG 2017), Imonyó-oldal (SzP 1995), Ravasz-lyuk (BG 2021), Sinai-oldal (BG 2021); Rudolftelep: Cseres-dúlő (BG 2021), Felső-rét (SzP 2006), Sürü-oldal (SzP 2021), Szekeres alja (SzP 2021); Sajógalgóc: Nagy-pallag (BG 
2017), Padi-földek (BG 2017); Szuhafő: Pálykás (SzP 2017), Zsilip-tető (SzP 2017); Trizs: Forrás-völgy (SzP 2021), Pallagok (SzP 2021); Zádorfalva: Bakó (SzP 2012), Bors-völgy (SzP 2010), Cseres alja (SzP 1995), Iván-tető (SzP 2016), Kis-erdő-tető (SzP 2012), Petrecz (SzP 2021), Pót-haraszt (SzP 2018), Ragyás-szőlő (SzP 2006), Szellő-tető (SzP 2006), Varjas-part (SzP 2012). Száraz gyepekben, vetésekben, általában szálanként, vagy néhány tucat töves állományokban került elő. [7588.4], [7589.3], [7688.2], [!7689.1], [7689.2], [!7689.3], [7689.4], [!7690.3], [!7789.1], [7789.2].

*980. Trifolium striatum L. - Herb.: Jósvafői-karszt: Aggtelek (Virók 2004, DE), Komjáti (Virók 2006, DE). Lit.: Jósvafői-karszt: Aggtelek (VIRóK \& FARKAS 2007). Ined.: Felsőnyárád: Kelecsényi-úton-aluli-dűlő (BG 2021). Réten. [!7689.4].

1004. Oxalis corniculata L. - Lit.: Flóratérképezési adatok [1]: Zubogy (Malatinszky Ákos és Penksza Károly 2003); Gömörszőlős (G. Farkas Tünde 2004). Ined.: Dövény: Belterület (SzP 2011); Felsőnyárád: Belterület (SzP 2021); Izsófalva: Belterület (SzP 2010). Járdaszéleken, kertekben. [!7689.3], [!7689.4].

1005. Oxalis dillenii Jacq. - Lit.: Flóratérképezési adat [1]: Felsőnyárád (Anonym 2005). Ined.: Jákfalva: Jákvarcsó (SzP 2021). Tarlón. [!7689.3].

1008. Geranium phaeum L. - Herb.: Putnok (Zólyomi 1928, BP). Lit.: Felsőkelecsény: Csörgős-patak mellett; Putnok; Serényfalva (VIRóK et al. 2004); Alsószuha: Bakóc-völgy (MoLNÁR et al. 2016). Ined.: Alsószuha: Határ-völgy (SzP 2009), Kocka-lápa-bérc (SzP 2009); Dövény: Belterület (SzP 2009); Felsőnyárád: Csörgős-patak (BG 2006), Fekete-völgy-Szuha (SzP 2009), Kelecsényi-úton-aluli-dűlő (BG 2006); Kurityán: Szuha (SzP 2008); Ragály: Csálos (BG 2013), Csörgős-szög (SzP 2010). Árnyas erdőkben, patakok mellett, kertben. [7689.1], [!7689.3], [!7689.4].

1010. Geranium palustre E. Torner - Herb.: Trizs (Sramkó 2008, DE). Lit.: Flóratérképezési adatok [1]: Jákfalva; Zubogy (Malatinszky Ákos és Penksza Károly 2003); Szuhafő (Virók Viktor 2004); Gömörszőlős; Kelemér (G. Farkas Tünde 2004). Ined.: Alsószuha: Alsó-rét (SzP 1996), Feneketlen (SzP 2014), Hegyes-hegy (SzP 2014); Felsőnyárád: Kelecsényiúton-felüli-dűlő (BG 2019); Ragály: Batyik-völgy (SzP 2010); Szuhafő: Alsó-rét (SzP 2006), Kerékkötő (SzP 2013), Korlát-patak völgye (SzP 2003), Pálykás (SzP 2006), Pető-háza (SzP 2009), Pető-házi-szőlő (SzP 2009), Szuha-völgy (SzP 2014), Virág-domb (SzP 2012); Trizs: Csörgős-lapos (SzP 2012), Kender-földek (SzP 2012), Pallagok (SzP 2011), Parcellás (SzP 2009), Páris-völgy (BG 2015); Zádorfalva: Latrány-völgy (SzP 2007), Szuha-völgy (SzP 2006), Varjas-völgy (SzP 1996). Magaskórósokban. [7588.4], [!7589.3], [7688.2], [7689.1], [!7689.4].

*1011. Geranium pratense L. - Lit.: Bódva-völgy: Bódvaszilas, Hidvégardó, Komjáti, Perkupa, Szalonna (VIRóK et al. 2016). Ined.: Felsőkelecsény: Aradvány (BG 2020), Csörgős-patak (BG 2020); Kurityán: Szuha (BG 2020); Szuhafő: Korlát-patak-völgye (SzP 2016); Szuhakálló: Hosszú-horvát (SzP 2006); Zubogy: Belterület, Csörgős-patak (SzP 2006). Patakok melletti magaskórósokban. [!7588.4], [!7689.1], [!7689.2], [!7689.4], [!7789.2].

*1015. Geranium dissectum Jusl. - Lit.: Aggteleki Fedett-karszt: Aggtelek; Bódva-völgy: Hidvégardó, Szögliget, Tornanádaska; Galyaság: Égerszög, Kánó, Perkupa, Tornakápolna; Rudabányai-hegység: Alsótelekes (VIRóK et al. 2016). Ined.: Dövény: Alsó-rét (SzP 2010), Belterület (SzP 2006), Kötél-föld (SzP 2021); Felsőkelecsény: Felső-rét (BG 2021), Szárazrét (SzP 2008); Felsőnyárád: Jákfalvi-dűlő (BG 2021), Kelecsényi-úton-felüli-dűlő (BG 2021); Jákfalva: Szőlők alja (SzP 2021); Ragály: Barom-szer (SzP 2010), Ortvány-kert (SzP 2008). Kertekben, gyomtársulásokban. [!7589.3], [!7689.2], [!7689.3]. [!7689.4].

*1018. Geranium divaricatum Ehrh. - Herb.: Jósvafői-karszt: Szögliget (Hulják 1929, GAH; Farkas R. 2014, DE). Ined.: Dövény: Belterület (SzP 2006). Gyomtársulásban. [!7689.3].

1030. Linum flavum L. - Lit.: Gömörszőlős: Kasza-hegy, Zánkó-hegy; Sajókaza: Ráró-hegy, Szár-hegy; Trizstől északra (PEnKSZA \& MALATinszKY 2001); Gömörszőlős: Kasza-hegy, Zán- 
kó-hegy; Kelemér és Gömörszőlős közötti hegyorron; Sajókaza: Ráró-hegy, Szár-hegy; Trizstől északra (MALATINSZKY 2004); Alsószuha: Virágos-oldal (Hegyes-hegy); Gömörszőlős; Kelemér; Zádorfalva: Iván-tető, Nagy-Szőlő-tető, Ragyás-szőlő, Rakottyás-tető (MALATINSZKY 2007); Gömörszőlős; Kelemér (FARKAS 2010); Alsószuha: Ôr-hegy (Feneketlen); Sajókaza (MALATinszkY \& ÁDÁm 2012); Sajókaza (Molnár et al. 2019). Ined.: Alsószuha: Hegyes-hegy (SzP 1996), Kánya-fő (SzP 1996); Felsőnyárád: Kővágó alja (SzP 1994), Mestergaz (SzP 1994); Kurityán: Susa-tető (BG 2020); Ragály: Gerenda-oldal (SzP 2009), Ortványkert (SzP 1995); Szuhafő: Cinege-bérc (SzP 2014), Pálykás (SzP 2010), Pető-háza (SzP 2010), Pető-házi-szőlő (SzP 1999), Pincék alja (SzP 1999), Puha-völgy (SzP 2014), Zsiliptető (SzP 2009); Trizs: Akasztó-bérc (SzP 2010), Comád (SzP 2013), Csörgős-patak völgye (SzP 2009), Eresztvény-tető (SzP 2009), Páris-völgy (SzP 2008), Rozsnyói-oldal (SzP 1999), Vermek-oldal (SzP 2008); Zádorfalva: Arany-kúti-oldal (SzP 2008), Bakó (SzP 2010), Cseres-völgy (SzP 2009), Iván-tető (SzP 1996), Kis-völgy (SzP 2021), Latrány-völgy (SzP 2007), Nagy-szőlő (SzP 1996), Nagy-szőlő alja (SzP 1996), Ragyás-szőlő (SzP 2005), Rakottyás-tető (SzP 1995), Rakottyás-völgy (SzP 2011), Szellő-tető (SzP 2018), Templomoldal (SzP 2009), Varjas-part (SzP 1996); Zubogy: Bodon alja (SzP 1996). A faj a Putnokidombságban nem ritka, szálkaperjés réteken csökkenő számban, de helyenként még több ezer töves állományai is előfordulnak. [7588.4], [7589.3], [7688.2], [7689.1], [7689.2], [7689.4].

1031. Linum tenuifolium L. - Lit.: Putnok: Hegyes-tető; Sajókaza: Ráró-hegy, Szár-hegy; Zádorfalva: Nagy-Szőlő-tető, Rakottyás-tető (PENKSZA \& MALATINSZKY 2001, MALATINSZKY 2004); Gömörszőlős; Kelemér; Ragály: Ortvány-kert; Szuhafő: Centu-hegy; Zádorfalva: Bors-völgy, Iván-tető, Nagy-Szőlő-tető, Ragyás-szőlő, Rakottyás-tető (MALATINSZKY 2007); Gömörszőlős; Kelemér (FARKAS 2010); Szuhafő: Temető (MoLNÁR V. \& LöKI 2018). Ined.: Alsószuha: Feneketlen (SzP 2014), Hegyes-hegy (SzP 2011), Kánya-fő (SzP 2001), Kis-kányafő (SzP 2006), Lác-oldal (SzP 2021), Lengyel-oldal (SzP 2019), Vad-répás (SzP 1995); Felsőnyárád: Mestergaz (SzP 1994); Izsófalva: Gede-tető (SzP 2006), Kavicsos (BG 2016), Mogyoróska (SzP 2006); Kurityán: Hársas-erdő (SzP 2006), Koritó (BG 2009), Kurityán-tető (SzP 1994), Susa-tető (SzP 2006), Temető alj (SzP 2014); Ragály: Ortvány-kert (SzP 2005); Rudolftelep: Edelényi-legelő (BG 2017), Felső-rét (SzP 1997); Szuhafő: Cinege-bérc (SzP 2011), Kis kútnál (SzP 2012), Korlát-patak-völgye (SzP 2019), Pálykás (SzP 2010), Petőháza (SzP 2010), Pincék alja (SzP 2000), Puha-völgy (SzP 2014), Tubóka (SzP 2020), Virágdomb (SzP 1996), Zsilip-tető (SzP 2012); Szuhakálló: Pince-tábla (BG 2018); Trizs: Akasztó-bérc (SzP 2010), Eresztvény-tető (SzP 2009), Rozsnyói-oldal (SzP 2009), Vermek lápa (SzP 2014); Zádorfalva: Arany-kúti-oldal (SzP 2009), Berek eleje (SzP 1995), Bütykös alja (SzP 2012), Cseres-völgy (SzP 2009), Iván-tető (SzP 1996), Latrány-völgy (SzP 2007), Nagy-szőlő (SzP 1996), Nagy-szőlő alja (SzP 1996), Potrec (SzP 2010), Ragyás-szőlő (SzP 2005), Rakottyás-tető (SzP 1995), Szellő-tető (SzP 1995), Temető (SzP 2021), Templomoldal (SzP 2009), Varjas-part (SzP 1996). A faj a Putnoki-dombságban nem ritka, szálkaperjés réteken elterjedt, helyenként sok száz töves állományokban. [7588.4], [7589.3], [7688.2], [7689.1], [7689.4], [7690.3], [7789.2].

1032. Linum hirsutum L. - Herb.: Trizs (Vojtkó 1999, BP). Lit.: Alsószuha: Lengyel-oldal; Gömörszőlős; Zádorfalva: Iván-tető, Nagy-Szőlő-tető, Ragyás-szőlő, Rakottyás-tető (MALATINSZKY 2007); Gömörszőlős (FARKAS 2010). Ined.: Alsószuha: Feneketlen (SzP 2017), Hegyes-hegy (SzP 1995), Kánya-fő (SzP 1996), Kánya-völgy (SzP 2021), Lác-oldal (SzP 2017), Vad-répás (SzP 1995); Felsőnyárád: Mestergaz (SzP 1995); Szuhafő: Cinege-bérc (SzP 2011), Pető-háza (SzP 2010), Pincék alja (SzP 2000), Virág-domb (SzP 1996), Zsilip-tető (SzP 1996); Trizs: Akasztó-bérc (SzP 2010), Eresztvény-tető (SzP 2009), Forrás-völgy (SzP 2019), Páris-völgy (BG 2015), Vermek-lápa (SzP 2016); Zádorfalva: Arany-kúti-oldal (SzP 2014), Bakó (SzP 1995), Latrány-völgy (SzP 2006), Nagy-kánya-fő (SzP 2009), Nagy-szőlő 
alja (SzP 1996), Rakottyás-tető (SzP 1995), Rakottyás-völgy (SzP 2011), Szellő-tető (SzP 1995), Varjas-part (SzP 1995), Varjas-völgy (SzP 2014). A faj a Putnoki-dombságban többfelé előfordul, főleg az északi részek szálkaperjés rétjein, bolygatott gyepjeiben, itt nagyobb (több száz töves) állományai is megtalálhatók. [7588.4], [!7589.3], [7688.2], [7689.1], [7689.4].

1034. Linum austriacum L. - Lit.: Zádorfalva: Bors-völgy, Nagy-Szőlő-tető (MALATINSZKY 2007). Ined.: Alsószuha: Gyámol-völgy (SzP 2004), Hegyes-hegy (SzP 2017), Kis-kánya-fő (SzP 2021), Lác-oldal (SzP 2010), Lengyel-odal (SzP 2019), Vad-répás (SzP 1995); Kelemér: Erdő-alatti-kaszáló (BG 2018); Szuhafő: Centu-hegy (SzP 2021), Kis kútnál (SzP 2009), Pálykás (SzP 2001), Pincék alja (SzP 2010); Zádorfalva: Almás (SzP 2014), Almás alja (SzP 2014), Arany-kúti-oldal (SzP 2009), Bakó (SzP 1996), Berek eleje (SzP 2005), Bütykös alja (SzP 2009), Cseres-völgy (SzP 2009), Iván-tető (SzP 2015), Latrány-völgy (SzP 2010), Nagy-kánya-fő (SzP 2010), Nagy-szőlő (SzP 2006), Nagy-szőlő alja (SzP 2008), Rakottyástető (SzP 1995), Szellő-tető (SzP 1995), Szuha-völgy (SzP 1995), Templom-oldal (SzP 2009), Varjas-part (SzP 2014). Száraz gyepekben. [7588.4], [7688.2], [!7688.4], [7689.1].

1045. Euphorbia platyphyllos L. - Lit.: Flóratérképezési adat [1]: Rudabánya (Matus Gábor és Virók Viktor 2001) Ined.: Felsőnyárád: Kelecsényi-úton-aluli-dűlő, elszórtan néhány tő (BG 2021), Kelecsényi-úton-felüli-dűlő (BG 2021). Parlagon, nedves gyomtársulásban. [!7689.4].

1052. Euphorbia epithymoides L. - Lit.: Felsőnyárád: Kővágó (MoLNÁr et al. 2017). Ined.: Szuhafó: Pálykás (SzP 2021); Trizs: Forrás-völgy (SzP 2021); Zádorfalva: Berek eleje (SzP 2009), Iván-tető (SzP 2021), Szellő-tető (SzP 2009). Sztyepréteken. [!7588.4], [!7688.2].

1064. Euphorbia peplus L. - Lit.: Gömörszőlős (MolNÁR et al. 2018). Ined.: Izsófalva: Alsórét (SzP 2006); Ragály: Barom-szer (SzP 2021). Kisparcellás szántóföldi gyomtársulásokban. [!7589.3], [!7789.2].

1068. Euphorbia falcata L. - Lit.: Gömörszőlős (MoLnÁR et al. 2017). Ined.: Alsószuha: Feneketlen (SzP 2021); Dövény: Alsó-rét (SzP 2021), Kötél-föld (SzP 2021). Sajó-völgy: Múcsony: Ragályi-szög (SzP 2006). Gyomtársulásokban. [!7689.1], [!7689.3], [!7790.1].

1070. Dictamnus albus L. - Lit.: Sajókaza: Ráró-hegy, Szár-hegy (PenKSZA \& MALATinSzKY 2001, MALATINSZKY 2004); Felsőkelecsény: Nagy-hegy (Kelecsényi-Nagy-hegy); Sajókaza; Sajógalgóc (MALATINSZKY \& ÁDÁM 2012); Sajógalgóc (TAKÁCS et al. 2016). Ined.: Felsőnyárád: Kővágó, 7 tő (SzP 2004); Kurityán: Ormos-hegy, 200 tő (SzP 1994); Sajókaza: Domonyóhegy, 200 tő (BG 2017). A Putnoki-dombságban ritka, mészkedvelő tölgyesekben fordul elö. [7689.4], [7789.1].

1074. Polygala major Jacq. - Herb.: Putnok (Zólyomi 1926, BP); Felsőnyárád: Mestergaz (Takács 2014, DE). Lit.: Gömörszőlős környéki felhagyott gyümölcsösökben; Putnok: Hegyes-tető; Sajókaza: Ráró-hegy, Szár-hegy; Szuhafő felett (PEnKSZA \& MALatinszKY 2001); Gömörszőlős és Alsószuha környéki tág térállású gyümölcsösökben és régen felhagyott szőlőkben; Putnok: Hegyes-tető; Sajókaza: Ráró-hegy, Szár-hegy; Szuhafő felett (MALATINSZKY 2004); Alsószuha: Virágos-oldal (Hegyes-hegy); Kelemér; Ragály: Ortvány-kert; Szuhafő: Pincék alja; Zádorfalva: Iván-tető, Kis-erdő-tető, Latrány, Nagy-Szőlő-tető, Ragyásszőlő, Rakottyás-tető (MALATINSZKY 2007); Gömörszőlős; Kelemér (FARKAS 2010); Gömörszőlős: Temető; Zádorfalva: Temető (MolnáR V. \& LöKI 2018); Sajókaza (MolNÁr et al. 2019). Ined.: Alsószuha: Feneketlen (SzP 2012), Hegyes-hegy (SzP 1996), Kánya-fő (SzP 1996), Kis-kánya-fő (SzP 2006), Lengyel-oldal (SzP 2014); Felsőnyárád: Kővágó alja (SzP 1994), Mestergaz (SzP 1994); Izsófalva: Meszes (SzP 2021); Kurityán: Susa-tető (BG 2010), Szőló-oldal (SzP 1994); Ragály: Gerenda-oldal (SzP 2009), Ortvány-kert (SzP 1995); Szuhafő: Centu-hegy (SzP 2008), Pálykás (SzP 2009), Pető-háza (SzP 1996), Pető-házi-szőlő (SzP 2009), Pincék alja (SzP 1996), Virág-domb (SzP 1996), Zsilip-tető (SzP 2010); Trizs: Akasztó-bérc (SzP 2008), Eresztvény-tető (SzP 2009), Forrás-völgy (SzP 2021); Zádorfalva: Al- 
más (SzP 2010), Arany-kúti-oldal (SzP 2008), Bakó (SzP 2009), Berek eleje (SzP 1995), Bors-völgy (SzP 2021), Bütykös alja (SzP 2009), Cseres alja (SzP 2009), Cseres-völgy (SzP 2009), Iván-tető (SzP 1995), Kis-völgy (SzP 2019), Latrány-völgy (SzP 2008), Nagy-kányafő (SzP 2009), Nagy-szőlő (SzP 1995), Nagy-szőlő alja (SzP 1995), Rakottyás-tető (SzP 1995), Rakottyás-völgy (SzP 2011), Szellő-tető (SzP 1995), Temető (SzP 2001), Templomoldal (SzP 2009), Varjas-part (SzP 1995). Szálkaperjés réteken, helyenként ezres állományokat alkot, a déli részeken ritkább. [7588.4], [7589.3], [7688.2], [7689.1], [7689.4].

*1080. Rhus typhina L. - Lit.: Jósvafői-karszt: Jósvafö, Szögliget (VIRóK et al. 2016). Ined.: Alsószuha: Belterület (SzP 2021); Ragály: Baglyos (BG 2015), Gerenda-oldal (BG 2015), Ortvány-kert (SzP 2004). Elvadulva. [!7589.3], [!7689.1].

1091. Impatiens glandulifera Royle - Lit.: Sajó-völgy: Sajókaza (MALATinsZKY \& PENKSZA 2002). Flóratérképezési adatok [1]: Jákfalva; Zubogy (Malatinszky Ákos és Penksza Károly 2003). Ined.: Dövény: Belterület, Szil-patak (SzP 2001), Szuha (SzP 2001), Varcsó-völgy (SzP 2007); Izsófalva: Ormos-patak (SzP 2006); Ormosbánya: Ormos-patak (SzP 2006). Vízparti magaskórósokban. [7689.3], [!7689.4].

**1128. Alcea rosea L. - Ined.: Dövény: Belterület (SzP 2007). Kivadulva. [!7689.3].

1129. Abutilon theophrasti Medik. - Lit.: Gömörszőlős (MoLNÁR et al. 2016). Ined.: Alsószuha: Dobos-dűlő (SzP 2021); Juhászat (SzP 2021), Kavacs-oldal (SzP 2018), Külső-rónya (SzP 2021); Dövény: Gödör-köz-dűlő (SzP 2016), Kötél-föld (SzP 2021); Felsőkelecsény: Száraz-rét (SzP 2009); Felsőnyárád: Aradvány (BG 2021), Gyökér-kúti-dűlő (BG 2021), Tövisespuszta (BG 2021); Jákfalva: Alsó-rét (SzP 2021), Köteles alja (SzP 2021), Németh-tag (BG 2020); Kurityán: Vaskapu (BG 2020); Ragály: Barom-szer (SzP 2021), Isten harasztja (SzP 2021); Szuhafő: Alsó-rét (SzP 2009); Zádorfalva: Arany-kúti-oldal (SzP 2018), Berek eleje (SzP 2021), Iván-tető (SzP 2011), Szuha-völgy (SzP 2021), Varjas-völgy (SzP 2021); Zubogy: Borsó-szer (BG 2021), Tanya alja (BG 2021). Terjedőben, szántókon, utak és vadszórók mellett. [!7588.4], [!7589.3], [7688.2], [!7689.1], [7689.2], [!7689.3], [!7689.4].

1130. Hibiscus trionum L. - Lit.: Bódva-völgy: Szendrő (MolNÁR et al. 2016). Flóratérképezési adatok [1]: Felsőnyárád (Anonym 2005); Jákfalva; Zubogy (Malatinszky Ákos és Penksza Károly 2003); Kelemér (G. Farkas Tünde 2004). Ined.: Alsószuha: Gyámol-völgy (SzP 2020), Hegyes-hegy (SzP 2021); Dövény: Alsó-rét (SzP 2010), Gödör-köz-dűlő (SzP 2016), Kötél-föld (SzP 2021); Felsőkelecsény: Aradvány (BG 2021), Csörgős-patak (BG 2020), Nyárádi-dűlő (BG 2021), Száraz-rét (BG 2020); Felsőnyárád: Aradvány (SzP 2007), Gyökérkúti-dúlő (BG 2021), Jákfalvi-dúlő (BG 2021), Kelecsényi-úton-aluli-dűlő (BG 2021), Kelecsényi-úton-felüli-dúlő (BG 2021); Izsófalva: Alsó-rét (SzP 2021), Kavicsos (BG 2020); Jákfalva: Szőlők alja (SzP 2009); Kurityán: Vaskapui-mocsár (BG 2021); Ragály: Barom-szer (SzP 2016), Isten harasztja (SzP 2021); Zubogy: Borsó-szer (BG 2021), Tanya alja (BG 2021). Sajó-völgy: Múcsony: Ragályi-szög. (SzP 2006). Szántókon, tarlókon, utak mellett. [!7589.3], [7689.1], [7689.2], [7689.3], [7689.4], [7789.2], [!7790.1].

1135. Thymelaea passerina (L.) Coss. et Germ. - Lit.: Gömörszőlős (MoLNÁr et al. 2016); Zádorfalva (MoLNÁR et al. 2019); Sajókaza (HASZonits et al. 2021). Ined.: Felsőkelecsény: Aradvány (BG 2021), Száraz-rét (BG 2021); Felsőnyárád: Jákfalvi-dűlő (BG 2021), Mestergaz (BG 2021); Zubogy: Suba-oldal (BG 2021). Nyílt gyepekben, földutak löszszerü, csupasz talajfelszínén. [7689.1], [7689.2], [!7689.4].

1163. Viola elatior Fr. - Lit.: Zubogy és Ragály között (Zubogy: Felső-rét) (SoMLYAY 2000); Dövény: Alsó-rét; Imola: Avas-oldal, a település mellett; Serényfalva és Kelemér közötti terület (MALATinszKY (2007). Ined.: Alsószuha: Vad-répás (SzP 2016); Dövény: Alsó-rét (SzP 2000); Felsőnyárád: Mestergaz (SzP 2006); Izsófalva: Alsó-rét (SzP 2000), Cseres-dúlő (SzP 2006); Jákfalva: Alsó-rét (SzP 2014), Köteles alja (SzP 2011); Kurityán: Fekete-völgy (SzP 2021); Múcsony: Cseres-szőlő (SzP 2016); Zádorfalva: Mocsolyás-völgy (SzP 2015), Ragyás-szőlő (SzP 2021), Szuha-völgy (SzP 2006), Varjas-part (SzP 2011), Varjas-völgy (SzP 
2011). Mocsárréteken, kaszálókon, magaskórósokban. [7688.2], [7689.1], [7689.3], [!7689.4], [7789.2], [!7790.1].

*1165. Viola pumila Chaix - Herb.: Bódva-völgy: Komjáti (Thaisz 1910, BP). Lit.: Bódvavölgy: Komjáti, Tornaszentandrás (VIRóK et al. 2016). Ined.: Alsószuha: Alsó-rét (SzP 2021); Dövény: Alsó-rét (SzP 2009); Jákfalva: Alsó-rét (SzP 2021), Falu-rét (SzP 2021). Mocsárréteken, állományai regionálisan jelentősek. [!7689.1], [!7689.3].

1194. Peplis portula L. - Lit.: Imola: Fekete-völgy (MALATinszKY 2007). Ined.: Felsőnyárád: Jákfalvi-dúlő (BG 2021). Kiszáradó belvízfolton. [!7689.4].

1220. Epilobium parviflorum Schreb. - Herb.: Jákfalva: Nagy-Varcsó-völgy (Virók 2003, DE). Lit.: Flóratérképezési adat [1]: Rudabánya (Matus Gábor és Virók Viktor 2001). Ined.: Alsószuha: Gyámol-völgy (SzP 2021), Ritka-dűlő (SzP 2021), Virág-oldal (SzP 2021); Dövény: Alsó-rét (SzP 2021), Kötél-föld (SzP 2021). Nádasokban, nedves gyomtársulásokban. [!7689.1], [!7689.3].

*1225. Epilobium roseum Schreb. - Herb.: Szalonnai-hegység: Bódvarákó (Virók 2005, DE). Lit.: Aggteleki Fedett-karszt: Aggtelek (VIRóK et al. 2016). Ined.: Dövény: Belterület (SzP 2011). A Szil-patak árnyas árkában. [!7689.3].

*1229. Myriophyllum spicatum L. - Lit.: Bódva-völgy: Hidvégardó, Perkupa, Szalonna; Galyaság: Szőlősardó; Rudabányai-hegység: Rudabánya (VIRóK et al. 2016). Ined.: Felsőnyárád: Mestergaz (SzP 2017); Izsófalva: Alsó-rét (SzP 2005), Alsó-réti bányatavak (SzP 2005), József-oldal (SzP 2011), Kavicsosi-bányató (SzP 2011), Kállói-tag (SzP 2013), Mák-völgyibánya (SzP 2021); Ormosbánya: Felső-bányató (SzP 2006), Gyilkos-tó (SzP 2006). Állóvizek és csatornák hínárnövényzetében. [!7689.4], [!7690.3], [7789.2].

1257. Bifora radians M. Bieb. - Herb.: Felsőkelecsény: Aradvány (Takács 2014, DE). Lit.: Gömörszőlős (PENKSZA et al. 1999/2000, SOMLYAY 2000, MALATINSZKY 2004); Gömörszőlős; Zádorfalva: Mocsolyás-völgy (PENKSZA \& MALATINSZKY 2001); Gömörszőlős: Cuda (MALATINSZKY 2008); Gömörszőlős (FARKAS 2010). Ined.: Felsőnyárád: Egyház megi dűlő (SzP 2007), Gyökér-kúti-dűlő (SzP 2006); Ragály: Barom-szer (SzP 2010), Ortvány-kert (SzP 2009); Trizs: Páris-völgy (SzP 2008); Zádorfalva: Latrány-völgy (SzP 2020). Szántókon. [!7588.4], [7589.3], [!7689.4].

1260. Pimpinella major (L.) Huds. - Herb.: Felsőkelecsény: Felső-rét (Virók 2004, DE). Lit.: Felsőkelecsény: Felső-rét; Gömörszőlős; Kelemér (VIRóK et al. 2010). Ined.: Felsőkelecsény: Csörgős-patak (BG 2020), Száraz-rét (BG 2020); Ragály: Hosszak-dűlő (BG 2020); Rudabánya: Ravasz-lyuk (BG 2020); Zubogy: Dobrosó-völgy (BG 2020), Kavacsos-oldal (BG 2020), Meskó-rét (BG 2020), Zúgó-patak (BG 2020), Zúgó-völgy (BG 2020). Magaskórósokban, erdőszélen. [!7689.1], [7689.2].

*1265. Berula erecta (Huds.) Coville - Herb.: Bódva-völgy: Bódvaszilas (Hulják 1933, DE). Lit.: Bódva-völgy: Bódvaszilas, Hidvégardó, Komjáti, Perkupa, Szalonna, Tornanádaska, Tornaszentandrás (VIRóK et al. 2016), Szalonna (MolNÁR et al. 2016). Ined.: Alsószuha: Belterület, Gyámol-patak (SzP 2021), Belterület, Szuha (SzP 2021); Dövény: Szuha (SzP 2016); Felsőnyárád: Szuha (BG 2020), Szuha alja (BG 2020); Izsófalva: Szuha (BG 2021); Jákfalva: Szuha (BG 2020); Kurityán: Fekete-völgy (BG 2021), Szuha (BG 2020); Ragály: Belterület, Csörgős-patak (SzP 2021); Zádorfalva: Belterület, Szuha (SzP 2021). Sajó-völgy: Szuhakálló: Belterület, Szuha (SzP 2021). Patakokban. [!7688.2], [!7689.1], [!7689.3], [!7689.4], [!7789.2].

1266. Libanotis pyrenaica Bourg. - Lit.: Szuhogy (MoLnÁR et al. 2017). Ined.: Felsőkelecsény: Borsó-szer (BG 2021), Bozsdár (BG 2020); Rudabánya: Agyagos-oldal (BG 2020), Ravasz-lyuk (BG 2020); Zubogy: Zúgó-völgy (BG 2020). Cserjések szegélyében, árokban. [7689.2].

1272. Seseli osseum Crantz. em. Simonk. - Lit.: Sajókaza (MolNÁr et al. 2017). Ined.: Alsószuha: Feneketlen (SzP 2021); Dubicsány: Galgóci-oldal (BG 2020); Felsőnyárád: Mestergaz 
(BG 2020); Zádorfalva: Ragyás-szőlő (SzP 2021); Zubogy: Suba-oldal (BG 2020). Felnyíló, nyílt gyepekben, löszszerú, csupasz talajfelszínen. [7688.2], [!7689.1], [!7689.4], [!7789.1].

1277. Aethusa cynapium L. - Herb.: Imola: Kerek-erdő (Virók 2002, DE). Lit.: Gömörszőlős (MolnÁR et al. 2016). Ined.: Felsőkelecsény: Csörgős-patak (BG 2020), Szakáll-hegy (BG 2020); Felsőnyárád: Csörgős-patak (BG 2020), Egyház megi dűlő (BG 2021); Kelecsényiúton-aluli-dúlő (BG 2020), Szuha (BG 2020); Zubogy: Csörgős-patak - falu feletti szakasz (BG 2020), Szuhucer (BG 2021). Üde ligetekben, gyomtársulásokban. [!7689.1], [7689.2], [!7689.4].

**1278. Foeniculum vulgare Mill. - Ined.: Zubogy: Dövény-szögi-dúlő (BG 2021), Tanya alja (BG 2021). Parlagon, elvadulva. 2021 augusztusában nagy területeken találtuk fejlődő hajtásait. [!7689.1].

**1294. Trinia ramosissima (Fisch.) W. D. J. Koch - Ined.: Izsófalva Cseres-dúlő (BG 2021); Múcsony: Cseres-szőlő (BG 2021); Rudolftelep: Cseres-dűlő (BG 2017). Sztyepréteken. [!7790.1].

1302. Selinum carvifolia L. - Lit.: Dubicsány (Soó et al. 1943). Flóratérképezési adat [1]: Szuhafő (Virók Viktor 2004). Ined.: Felsőnyárád: Egyház megi dűlő (BG 2020); Jákfalva: Gyökér-kúti-rét (BG 2020); Ragály: Kis-Talló (BG 2020); Sajókaza: Pap-szőlők (BG 2020); Zubogy: Dobrosó-völgy (BG 2020), Suba-oldal (BG 2020). Nedves réteken. [!7689.1], [!7689.4].

1333. Pyrola rotundifolia L. - Herb.: Imola (Soó 1936, BPU). Lit.: Imola (Soó et al. 1943). Ined.: Jákfalva: Németh-tag, 2 virágzó tő (BG 2010). Fenyőkkel, nyárakkal szegélyezett kb. 3 méter mély árokban. [!7689.3].

1338. Monotropa hypopitys L. s. str. - Lit.: Trizs: Kerek-erdő; Zádorfalva: Galyagos-hegy (MALATINSZKY 2007); Gömörszőlős (HASZoNiTs et al. 2021). Ined.: Alsószuha: Határ-völgy (SzP 2009), Kavacs-oldal (SzP 2020); Dövény: Pencs-tető (SzP 2009); Kurityán: Ormoshegy (BG 2020); Zádorfalva: Bakó (SzP 2014), Bütykös-oldal (SzP 2011), Nagy-völgy (SzP 2014). Gyertyános-tölgyesekben, telepített fenyvesekben. [7588.4], [!7689.1], [!7689.4].

1349. Primula elatior (L.) Hill - Lit.: Alsószuha: Bakóc-völgy (MALATiNSZKY 2007). A Tornenséből további 2 adata ismert, mindkettő a Jósvafői-karsztról: Aggtelek (VojTKó et al. 1998) és Szögliget (VIRóK \& FARKAS 2007). Ined.: Alsószuha: Bakóc-völgy, 2009-ben 312 tő, majd csökkent az állomány, 2021-ben csak 29 tő került elő. (SzP 2001). Gyertyános-tölgyesben a Cardamine glanduligera 0. Schwarz-cal és a Scilla kladnii Schur-ral együtt virágzik. [7689.1].

1362. Anagallis foemina Mill. - ㅂerb.: Galyaság: Szőlősardó (Virók 2004, DE). Lit.: Galyaság: Perkupa, Szőlősardó; Tornakápolna (VIRóK \& FARKAS 2007). Flóratérképezési adat [1]: Gömörszőlős (G. Farkas Tünde 2003). Ined.: Alsószuha: Kánya-völgy (SzP 2017), Vad-répás (SzP 2017); Felsőkelecsény: Száraz-rét (BG 2021); Kurityán: Susa-tető (SzP 2008); Ragály: Csornok (SzP 2010), Dégány (SzP 2009), Ortvány-kert (SzP 2006); Szuhafő: Korlát-patakvölgye (SzP 2014); Trizs: Rozsnyói-oldal (SzP 2010); Zádorfalva: Cseres-völgy (SzP 2010), Latrány-völgy (SzP 2007), Nagy-szőlő (SzP 2021), Nagy-szőlő alja (SzP 2009), Rakottyástető (SzP 2016), Szellő-tető (SzP 2010), Szuha-völgy (SzP 2016); Zubogy: Suba-oldal (BG 2016). Szántókon, gyomtársulásokban. [!7588.4], [!7589.3], [7688.2], [!7689.1], [!7689.2], [!7689.4].

*1382. Centaurium pulchellum (Sw.) Druce - Herb.: Aggteleki Fedett-karszt: Aggtelek (Somlyay 1999, BP); Bódva-völgy: Edelény (Budai 1906, BP), Bódvaszilas (Hulják 1933, BP, DE); Galyaság: Szőlősardó (Virók 2004, DE); Rudabányai-hegység: Alsótelekes (Virók 2004, DE). Lit.: Bódva-völgy: Bódvaszilas (HuLjÁK 1937); Aggteleki Fedett-karszt: Aggtelek; Bódva-völgy: Bódvalenke, Bódvarákó, Bódvaszilas, Hidvégardó, Komjáti, Perkupa; Galyaság: Varbóc; Rudabányai-hegység: Alsótelekes, Rudabánya (VIRóK et al. 2016). Ined.: Dövény: Alsó-rét (SzP 2021); Felsőkelecsény: Aradvány (BG 2021); Felsőnyárád: Kelecsényi-úton- 
aluli-dűlő (BG 2021), Kelecsényi-úton-felüli-dűlő (BG 2021), Mestergaz (BG 2021); Kurityán: Fekete-völgy (BG 2021), Hencel-szög (SzP 2011). Nedves talajon, parlagon, keréknyomban, szivárgások, kisebb források körül. [7689.2], [!7689.3], [!7689.4].

1384. Gentiana cruciata L. - Lit.: Gömörszőlős; Szuhafő: Centu-hegy; Trizs; Zádorfalva: Cseres-völgy mellett, Rakottyás-tető (PENKSZA \& MALATINSZKY 2001); Zádorfalva: Iván-tető, Latrány, Ragyás-szőlő (MALATINSZKY 2007); Alsószuha: Virágos-oldal (Hegyes-hegy) (MALATINSZKY \& ÁDÁM 2012); Szuhogy (MolnáR et al. 2017); Gömörszőlős (Molnár et al. 2018). Ined.: Alsószuha: Kis-kánya-fő, 18 tő (SzP 2014), Lengyel-oldal, 6 tő (SzP 2020), Megyeberek, 4 tő (SzP 2014), Vad-répás, 6 tő (SzP 2018); Felsőkelecsény: Aradvány alja (BG 2020); Felsőnyárád: Mestergaz (BG 2010), Válós-út alja (BG 2019); Kurityán: Koritó (BG 2020), Susa-tető (BG 2009), Szőlő-oldal (BG 2014); Ragály: Ravasz-rész, 3 tő (SzP 2010); Trizs: Parcellás, 32 tő (SzP 2019), Rozsnyói-oldal, 14 tő (SzP 2010), Vermek-oldal (BG 2015); Zádorfalva: Bakó, 3 tő (SzP 2014), Berek eleje, 24 tő (SzP 2014), Bors-völgy, 2 tő (SzP 2021), Bütykös alja, 3 tő (SzP 2016), Cseres alja, 11 tő (SzP 2020), Kiserdő-tető, 112 tő (SzP 2010), Nagy-kánya-fő, 6 tő (SzP 2014), Nagy-szőlő, 38 tő (SzP 2014), Nagy-szőlő alja, 9 tő (SzP 2006), Petrecz, 7 tő (SzP 2017), Ragyás-szőlő, 11 tő (SzP 2002), Szellő-tető, 19 tő (SzP 2014), Templom-oldal, 4 tő (SzP 2020), Varjas-part, 46 tő (SzP 2021). Franciaperjés réteken, szálkaperjés és mészkerülő gyepekben. [7588.4], [7589.3], [7688.2], [7689.1], [7689.2], [7689.4].

1385. Gentiana pneumonanthe L. - Lit.: Flóratérképezési adat [1]: Imola (Vojtkó András 2001). Ined.: Szuhafő: Pető-házi-szőlő, 10 tő (SzP 2005). Az állományt Hudák Katalin és Visnyovszky Tamás közlése alapján hegytetői Molinietumban találtuk. [!7688.2].

1387. Gentianopsis ciliata (L.) Ma - Lit.: Zádorfalva: Iván-tető (MALATINSZKY 2007). Ined.: Zádorfalva: Varjas-part, 16 tő (SzP 2005). Sztyepréten. (A két dűlő egymás szomszédságában található, a két adat ugyanarra az állományra vonatkozik, mivel a közléskor rendelkezésre állt térképek ezt a részt is Iván-tetőként jelezték, így az irodalomban nem Varjaspartként szerepelt.) [7688.2].

1395. Asclepias syriaca L. - Lit.: Flóratérképezési adatok [1]: Jákfalva; Zubogy (Malatinszky Ákos és Penksza Károly 2003). Sajó-völgy: Múcsony: Duzsnok (VIRóK et al. 2010). Ined.: Alsószuha: Alsó-rét (SzP 2009), Feneketlen (SzP 2019), Hegyes-hegy (SzP 2019), Kánya-fö (SzP 2019), Kánya-völgy (SzP 2019), Milló-dűlő (BG 2016), Ritka-dűlő (SzP 2014), Ritkaoldal (SzP 2009), Vad-répás (SzP 2019); Felsőkelecsény: Aradvány (BG 2021), Bozsdár (BG 2021), Sár-völgy-erdő (BG 2020), Száraz-rét (BG 2020); Felsőnyárád: Kazai-dúlő (BG 2018), Kelecsényi-úton-aluli-dűlő (BG 2020), Németh-tag (BG 2020), Válós-út alja (BG 2021); Izsófalva: Alsó-rét (SzP 2008), Kavicsos (BG 2020), Koplaló (SzP 2021); Jákfalva: Nagy-föld-dúlő (BG 2020), Németh-tag (BG 2020); Kurityán: Malom-mező (BG 2020); Múcsony: Cseres-szőlő (BG 2021); Putnok: Kedves (BG 2018), Pál-völgy (BG 2018); Szuhafő: Virág-domb (SzP 2017); Zádorfalva: Bütykös alja (SzP 2009), Nagy-szőlő alja (SzP 2016), Varjas-part (SzP 2021); Zubogy: Dövény-szögi-dűlő (BG 2021), Kert alja (BG 2021), Subaoldal (BG 2017). Bolygatott területeken (így külszíni szénbánya meddőhányója, szárzúzott hegyi rétek) terjedőben. [!7588.4], [!7688.2], [!7688.4], [7689.1], [!7689.2], [!7689.4], [7789.2], [7788.2], [7790.1].

1409. Cuscuta europaea L. - Lit.: Flóratérképezési adat [1]: Szuhafő (Virók Viktor 2004). Ined.: Alsószuha: Kánya-völgy (SzP 2021); Dövény: Kötél-föld (SzP 2012), Pencs alja (SzP 2021); Jákfalva: Köteles alja (SzP 2012); Kurityán: Fekete-völgy (SzP 2012). Gyomtársulásokban. [!7689.1], [!7689.3], [!7689.4].

1422. Echium maculatum L. - Lit.: Putnok: Hegyes-tető; Sajókazától északkeletre fekvő hegy (Ráró-hegy) (Penksza \& MaLATinszKY 1999/2000); Putnok: Hegyes-tető (SomlyaY 2000); Sajókazától északnyugatra fekvő hegy (Csüre), Sajókaza: Ráró-hegy (PENKSZA \& MALATINSZKY 2001, MALATINSZKY 2004); Gömörszőlős; Kelemér (FARKAS 2010). Ined.: Múcsony: 
Cseres-szőlő, 216 tő (SzP 2006), Meleg-oldal, 821 tő (SzP 2006); Sajógalgóc: Padi-földek, 1 tő (BG 2017). Sztyepréteken, löszös területen. [7789.1], [!7790.1].

*1451. Myosotis ramosissima Rochel - Lit.: Aggteleki Fedett-karszt: Aggtelek; Bódva-völgy: Perkupa, Szalonna, Szögliget; Galyaság: Kánó (VIRóK et al. 2016). Ined.: Ragály: Barom-szer (SzP 2021). Száraz gyepben. [!7589.3].

1455. Lappula squarrosa (Retz.) Dumort. - Lit.: Sajókaza (HASzonits et al. 2021). Ined.: Alsószuha: Nádas-rét (SzP 2010), Ritka-oldal (SzP 2010); Kurityán: Belső-szög (BG 2021). Száraz gyomtársulásokban. [!7689.1], [!7689.4].

**1461. Phacelia tanacetifolia Benth. - Ined.: Alsószuha: Bakócz (SzP 2012), Ritka-dűlő (SzP 2016); Dövény: Alsó-rét (SzP 2012), Kerek-föld (SzP 2021); Felsőnyárád: Holdas (SzP 2012), Őr-hegy (BG 2012); Trizs: Páris-völgy (SzP 2011). Méhlegelőnek, zöldtrágyának termesztik, elvadul. [!7588.4], [!7689.1], [!7689.3], [!7689.4].

1466. Callitriche cophocarpa Sendtn. - Herb.: Szuhafő: Szuha-völgy (Virók 2004, DE). Lit.: Flóratérképezési adatok [1]: Gömörszőlős; Kelemér (G. Farkas Tünde 2003). Ined.: Alsószuha: Hegyes-hegy (SzP 2015), Kánya-völgy (SzP 2014); Jákfalva: Gyökér-kúti-mocsár (SzP 2021). Tócsákban. [!7689.1], [!7689.4].

1470. Ajuga chamaepitys (L.) Schreb. - Herb.: Cserehát: Szendrőlád (Budai 1914, BP). Lit.: Gömörszőlős (MolnÁR et al. 2018). Ined.: Kurityán: Susa-tető (BG 2010), Szőlő-oldal (SzP 2008); Zubogy: Bodon alja (BG 2021). Száraz gyepekben néhány töves állományait találtuk. [!7689.2], [!7689.4].

1475. Teucrium montanum L. - Lit.: Gömörszőlős; Sajókaza (PENKSZA \& MALATINSZKY 1999). Ined.: Alsószuha: Feneketlen (SzP 2021); Sajókaza: Csüre (BG 2014); Zádorfalva: Berek eleje (SzP 2009), Bütykös alja (SzP 2011), Cseres-völgy (SzP 2021), Nagy-szőlő alja (SzP 2013), Rakottyás-tető (SzP 2010), Varjas-part (SzP 2010). Szálkaperjés gyepekben. [!7588.4], [7688.2], [!7689.1], [7789.1].

1488. Phlomis tuberosa L. - Lit.: Gömörszőlős (FARKAS 2010). Ined.: Felsőkelecsény: Aradvány alja (BG 2018); Felsőnyárád: Kővágó (BG 2020), Kővágó alja (SzP 1994); Izsófalva: Kavicsos (SzP 1994); Múcsony: Meleg-oldal (SzP 1996); Sajókaza: Szár-hegy (SzP 1994). Sajó-völgy: Múcsony: Szentpéteri-szög (SzP 2010). Sztyepréteken, száraz tölgyesben, löszön. [!7689.2], [7689.4], [7789.2], [!7790.1].

1490. Galeopsis Iadanum L. - Lit.: Dubicsány (Soó et al. 1943). Flóratérképezési adat [1]: Felsőnyárád (Anonym 2005). Ined.: Jákfalva: Borcsog-föld (BG 2020). Szárzúzott, visszacserjésedő gyepen. [!7689.3].

1494. Galeopsis tetrahit L. - Lit.: Flóratérképezési adat [1]: Szuhafő (Virók Viktor 2004). Ined.: Jákfalva: Köteles (SzP 2006); Szuhafő: Virág-domb (SzP 2021). Gyomtársulásban. [7588.4], [!7689.3].

1495. Galeopsis bifida Boenn. - Lit.: Sajó-völgy: Sajókaza (HASZoniTs et al. 2021). Flóratérképezési adatok [1]: Jákfalva; Zubogy (Malatinszky Ákos és Penksza Károly 2003). Ined.: Kurityán: Hársas-erdő (BG 2020), Kurityán-tető (BG 2020); Zádorfalva: Cseres alja (SzP 2014). Árnyékolt, nitrogénben gazdag, laza erdei talajon. [!7588.4], [!7689.4].

1505. Leonurus marrubiastrum L. - Lit.: Sajókaza (HASZONITS et al. 2021). Flóratérképezési adat [1]: Szuhafő (Virók Viktor 2004). Ined.: Alsószuha: Ritka-dűlő (SzP 2012); Dövény: Pencs-tető (SzP 2011); Felsőkelecsény: Száraz-rét (BG 2021); Felsőnyárád: Kelecsényiúton-felüli-dűlő (BG 2020); Ragály: Dobrosó-oldal (SzP 2011). Gyomtársulásokban. [!7589.3], [!7689.1], [7689.2], [!7689.4].

*1517. Nepeta cataria L. - Herb.: Jósvafói-karszt: Jósvafő (Károlyi 1961, BP, Vojtkó 2000, BP). Szalonnai-hegység: Bódvarákó (Vojtkó 2004, BP). Lit.: Bódva-völgy: Szalonna; Jósvafő́ikarszt: Bódvaszilas, Jósvafő, Szögliget (VIRóK et al. 2016). Ined.: Kurityán: Szőlő-oldal (BG 2020). Gyomtársulásban. [!7689.4]. 
1522. Prunella laciniata L. - Lit.: Kelemér; Gömörszőlős (MolnáR et al. 2017). Ined.: Alsószuha: Bakóc-oldal (SzP 2010), Feneketlen (SzP 2009), Gyámol-völgy (SzP 2009), Hegyeshegy (SzP 2015), Jegenye-völgy (SzP 2006), Kánya-fó (SzP 2019), Ritka-dűlő (SzP 2010), Ritka-oldal (SzP 2021); Dövény: Pencs-oldal (SzP 2009), Varcsó-völgy (SzP 2021); Felsőkelecsény: Galagonyás (BG 2010); Felsőnyárád: Kelecsényi-úton-aluli-dűlő (BG 2020), Kővágó alja (BG 2006), Mestergaz (SzP 2006), Nagy-erdő (BG 2013), Őr-hegy (BG 2005); Izsófalva: Cseres-dűlő (SzP 2006), Gede-tető (SzP 2006), Kopasz-tető (SzP 2006); Jákfalva: Gyomoroldal (SzP 2020), Kazai-oldal (SzP 2018), Nyírjes (SzP 2006); Kurityán: Belterület (SzP 2006), Koritó (SzP 2006), Susa-tető (SzP 2006), Szőlő-oldal (SzP 2006); Ragály: Batyikvölgy (SzP 2010), Ortvány-kert (SzP 2018); Sajógalgóc: Padi-földek (BG 2017); Sajókaza: Nagy-domonyó (BG 2017); Szuhafő: Centu-hegy (SzP 2017), Cinege-bérc (SzP 2018), Kis kútnál (SzP 2017), Pálykás (SzP 2010), Pető-háza (SzP 2010), Pincék alja (SzP 2010), Temető (SzP 2021), Tubóka (SzP 2018), Virág-domb (SzP 2018); Trizs: Akasztó-bérc (SzP 2016), Rozsnyói-oldal (SzP 2016); Zádorfalva: Arany-kúti-oldal (SzP 2010), Berek eleje (SzP 2021), Bors-völgy (SzP 2009), Bütykös alja (SzP 2012), Cseres-völgy (SzP 2021), Ivántető (SzP 2009), Latrány (SzP 2021), Latrány-völgy (SzP 2018), Nagy-szőlő (SzP 2011), Nagy-szőlő alja (SzP 2010), Ragyás-szőlő (SzP 2006), Rakottyás-tető (SzP 2009), Szellő-tető (SzP 2021), Varjas-part (SzP 2021); Zubogy: Suba-oldal (BG 2016). Száraz gyepekben. [!7588.4], [7589.3], [7688.2], [7689.1], [7689.2], [7689.3], [7689.4], [!7789.1], [!7789.2], $[! 7790.1]$.

$1522 \times 1523$. Prunella $\times$ intermedia Link (Prunella laciniata L. $\times$ vulgaris L.) $-\underline{\text { Herb.: Trizs }}$ (Boros 1953, BP). Ined.: Alsószuha: Ritka-oldal (SzP 2021); Dövény: Varcsó-völgy (SzP 2021); Felsőnyárád: Kelecsényi-úton-aluli-dűlő (BG 2020); Kurityán: Susa-tető (BG 2020); Szuhafő: Centu-hegy (SzP 2021); Zádorfalva: Varjas-part (SzP 2021). Száraz gyepekben a szülőfajokkal. [!7588.4], [!7688.2], [!7689.1], [!7689.3], [!7689.4].

1524. Prunella grandiflora (L.) Scholler - Lit.: Szuhafő és Gömörszőlős közötti terület (Zádorfalva: Iván-tető) (PENKSZA \& MALATINSZKY 2001); Gömörszőlős; Zádorfalva: Latrány (MALATINSZKY 2007); Gömörszőlős: Temető (MoLnÁR V. \& LöKI 2018). Ined.: Sajókaza: Rárószőlő (BG 2014); Szuhafő: Korlát-patak völgye (SzP 2014), Pálykás (SzP 2014), Pető-háza (SzP 2010), Pető-házi-szőlő (SzP 2006); Zádorfalva: Bütykös-oldal (SzP 2011), Cseres-völgy (SzP 2006), Iván-tető (SzP 1996), Kis-völgy (SzP 2011), Latrány-völgy (SzP 2007), Nagyszőlő alja (SzP 2009), Ragyás-szőlő (SzP 2006), Rakottyás-tető (SzP 1999), Rakottyás-völgy (SzP 2011), Szellő-tető (SzP 2010), Varjas-part (SzP 1996). A faj a Putnoki-dombságban ritka, nagyobb számban az északi részek száraz gyepjeiben, erdőszegélyeiben fordul elő. [7588.4], [7688.2], [!7789.2].

1542. Lycopus exaltatus L. f. - Lit.: Flóratérképezési adat [1]:. Felsőnyárád (Anonym 2005). Ined.: Alsószuha: Feneketlen (SzP 2014); Felsőkelecsény: Bozsdár (BG 2020); Felsőnyárád: Jákfalvi-dúlő (BG 2021), Kelecsényi-úton-aluli-dűlő (BG 2021), Szuha alja (BG 2021); Kurityán: Fekete-völgy (BG 2020), Szuha (BG 2021). Nedves réteken, gyomtársulásokban. [!7689.1], [7689.2], [7689.4].

$* 1541 \times 1542 . \quad$ Lycopus $\times$ intercedens Rech. (Lycopus europaeus L. $\times$ exaltatus L. f.) $-\underline{\text { Ined.: }}$ Kurityán: Fekete-völgy (BG 2020), Vaskapu (BG 2021). Nedves réten, kiszáradt belvízfolton. [!7689.4].

1543. Mentha pulegium L. - Lit.: Sajó-völgy: Putnok; Sajókaza (MalatinszKY \& PenKsZA 2002). Flóratérképezési adat [1]: Gömörszőlős (G. Farkas Tünde 2003). Ined.: Alsószuha: Feneketlen (SzP 2021); Felsőkelecsény: Felső-rét (BG 2020); Ragály: Dégány (SzP 2006), Dobrosó-oldal (SzP 2006); Zádorfalva: Szuha-völgy (SzP 2006). Nedves legelőkön. [!7589.3], [7688.2], [!7689.1], [7689.2].

1560. Salvia austriaca Jacq. - Lit.: Rudabánya (Soó et al. 1943). Flóratérképezési adatok [1]: Szuhafő (Virók Viktor 2004); Gömörszőlős (G. Farkas Tünde 2003). Ined.: Alsószuha: Fene- 
ketlen (SzP 2016), Hegyes-hegy (SzP 2008), Kánya-völgy (SzP 2009); Múcsony: Cseresszőlő (SzP 2006), Meleg-oldal (SzP 2006); Sajógalgóc: Padi-földek (BG 2017); Szuhafó: Centu-hegy (SzP 2008), Kerékkötő (SzP 2014), Kis kútnál (SzP 2009), Pető-háza (SzP 2006), Pincék alja (SzP 2021), Virág-domb (SzP 2009), Zsilip-tető (SzP 2016); Zádorfalva: Almás (SzP 2018), Almás alja (SzP 2018), Arany-kúti-oldal (SzP 2008), Bakó (SzP 2009), Berek eleje (SzP 2006), Bütykös alja (SzP 2009), Cseres-völgy (SzP 2009), Latrány-völgy (SzP 2008), Nagy-kánya-fő (SzP 2009), Nagy-szőlő alja (SzP 2011), Potrec (SzP 2011), Ragyásszőlő (SzP 2010), Rakottyás-tető (SzP 2006), Szuha-völgy (SzP 2011), Templom-oldal (SzP 2009), Varjas-part (SzP 2011). Száraz gyepekben. [7588.4], [7688.2], [!7689.1], [!7789.1], [!7790.1].

1567. Lycium barbarum L. - Lit.: Flóratérképezési adatok [1]: Jákfalva; Zubogy (Malatinszky Ákos és Penksza Károly 2003); Gömörszőlős; Kelemér (G. Farkas Tünde 2003). Ined.: Dövény: Belterület (SzP 2006); Dubicsány: Gyöngyös-hegy (BG 2017); Izsófalva: Belterület (SzP 2006), Kavicsos (SzP 2021). Elvadulva sövényekből, túlélő egyedek, Izsófalva: Kavicsoson szubspontán. [7689.3], [!7689.4], [!7788.2].

1571. Hyoscyamus niger L. - Lit.: Flóratérképezési adatok [1]: Jákfalva; Zubogy (Malatinszky Ákos és Penksza Károly 2003). Ined.: Kurityán: Belső-szög (SzP 2006), Vaskapu (BG 2016). Gyomtársulásokban. [!7689.4].

1590. Gratiola officinalis L. - Herb.: Sajó-völgy: Kazincbarcika (Kárpáti 1929, BP). Lit.: Sajóvölgy: Dubicsány (MALATinszKY \& PENKSZA 2002). Flóratérképezési adatok [1]: Gömörszőlős; Kelemér (G. Farkas Tünde 2004). Ined.: Alsószuha: Ritka-dűlő (SzP 2011); Dövény: Felső-rét (SzP 2000); Felsőnyárád: Gyökér-kúti-dủlő (BG 2020); Jákfalva: Gyökér-kúti-rét (SzP 2006). Árkokban, nedves réten. [!7689.1], [!7689.4].

*1593. Limosella aquatica L. - Herb.: Bódva-völgy: Edelény (Budai 1914, BP); Aggteleki Fedett-karszt: Aggtelek (Somlyay 1998, BP; Virók 2002, DE). Lit.: Aggteleki Fedett-karszt: Aggtelek (SOMLYAY \& LőKÖS 1999; VIRóK et al. 2016); Bódva-völgy: Edelény (BuDAI 1914); Szögliget (VIRóK et al. 2010); Bódvarákó, Komjáti, Szögliget (VIRóK et al. 2016). Ined.: Dövény: Varcsó (SzP 2011). Keréknyomban kialakult tócsában. [!7689.3].

1619. Kickxia spuria (L.) Dumort. - Herb.: Zádorfalva (Nagy 2014, DE). Lit.: Zádorfalva (TAKÁCS et al. 2016); Gömörszőlős (MolNÁR et al. 2018). Ined.: Felsőnyárád: Kelecsényi-útonaluli-dűlő (BG 2021). Szántóföldi gyomtársulásban. [!7689.4].

1620. Kickxia elatine (L.) Dumort. - Lit.: Gömörszőlős (FARKAS 2010); Sajókaza (HASZONITS et al. 2021). Ined.: Felsőnyárád: Egyház megi dűlő (BG 2021), Jákfalvi-dűlő (BG 2021), Kelecsényi-úton-aluli-dúlő (BG 2021), Kelecsényi-úton-felüli-dúlő (BG 2021); Zubogy: Kert alja (BG 2021). Szántóföldi gyomtársulásokban. [7689.1], [!7689.4].

1625. Pseudolysimachion longifolium (L.) Opiz - Herb.: Trizs (Jávorka és Zólyomi 1949, BP); Rudabánya: Imonyó-bérc (Farkas R. 2001, DE); Szuhafő: Korlát-patak völgye (Nagy 2014, DE). Lit.: Szuhafő: Korlát-patak (TAKÁCS et al. 2016); Gömörszőlős (MoLNÁR et al. 2018). Ined.: Alsószuha: Bakócz (SzP 2011); Dövény: Alsó-rét (SzP 2009), Felső-rét (SzP 2019), Gödör-köz-dűlő (SzP 2009), Kötél-föld (SzP 2006); Felsőkelecsény: Felső-rét (BG 2020); Felsőnyárád: Aradvány (BG 2020), Csörgős-patak (BG 2020), Kelecsényi-úton-alulidúlő (BG 2020), Németh-tag (BG 2020), Szuha alja (BG 2021); Imola: Bodzás-tető (SzP 2015), Somos-tető (SzP 2015); Izsófalva: Gede-tető (SzP 2006); Jákfalva: Alsó-rét (SzP 2000), Falu-rét (SzP 2009), Kender-földek (SzP 2011); Kurityán: Temető alj (SzP 2014); Múcsony: Cseres-szőlő (BG 2021), Hrabina (BG 2021); Szuhafő: Alsó-rét (SzP 2015); Zubogy: Bodon alja (BG 2021), Zúgó-patak (BG 2021), Zúgó-völgy (BG 2021). Nedves réteken, magaskórósokban. [7588.4], [!7589.3], [!7689.1], [7689.2], [!7689.3], [7689.4], [7789.2], [!7790.1].

1629. Pseudolysimachion orchideum (Crantz) Waber - Lit.: Flóratérképezési adat [1]: Szuhafő (Virók Viktor 2004). Ined.: Felsőkelecsény: Szakáll-szőlő (BG 2021); Felsőnyárád: Kő- 
vágó, (BG 2020), Válós-út alja (BG 2021). Cseres-tölgyes erdőszegélyben. [!7689.2], [!7689.4].

*1630. Veronica scutellata L. - Herb.: Aggteleki Fedett-karszt: Aggtelek (Jakucs 1913, BP); Bódva-völgy: Komjáti (Thaisz 1909, BP); Bódva-völgy: Bódvaszilas (Boros 1922, BP; Hulják 1928, GAH; Hulják 1933, GAH). Lit.: Bódva-völgy: Komjáti (THAISZ 1910); Sajó-völgy: Putnok (MALATinsZKY \& PENKSZA 2002); Aggteleki Fedett-karszt: Aggtelek; Bódva-völgy: Bódvalenke, Bódvaszilas, Hidvégardó, Komjáti, Szögliget, Tornaszentandrás (VIRóK et al. 2016). Ined.: Dövény: Belterület (SzP 2008); Felsőnyárád: Kelecsényi-úton-aluli-dűlő (BG 2021). Árokban, illetve időszakosan vízállásos mélyedésben. [!7689.3], [!7689.4].

1660. Melampyrum cristatum L. - Lit.: Flóratérképezési adat [1]: Kelemér (G. Farkas Tünde 2004). Ined.: Felsőnyárád: Válós-út alja (SzP 2006); Szuhafő: Pető-háza (SzP 2006); Zádorfalva: Cseres-völgy (SzP 2009), Iván-tető (SzP 2006), Ragyás-szőlő (SzP 2006). Szálkaperjés réteken, erdőszegélyeken. [!7588.4], [!7688.2], [!7689.4].

1662. Melampyrum barbatum Waldst. et Kit. - Lit.: Flóratérképezési adat [1]: Felsőnyárád (Anonym 2005). Ined.: Felsőnyárád: Őr-hegy (BG 2021); Izsófalva: Gede-tető (SzP 2006), Koplaló (SzP 2009), Sưrű-tető (SzP 2021); Kurityán: Malom-mező (BG-SzP 2021), Susa-tető (SzP 2006); Rudolftelep: Felső-rét (SzP 2006), Gede-oldal (SzP 2021), Sürü-oldal (SzP 2021); Trizs: Akasztó-bérc (SzP 2015); Zádorfalva: Nagy-szőlő alja (SzP 2010), Rakottyástető (SzP 2012), Templom-oldal (SzP 2009). Száraz gyepekben. [!7588.4], [!7589.3], [!7688.2], [7689.4], [!7690.3], [!7789.2].

1666. Euphrasia rostkoviana Hayne - Herb.: Rudabányai-hegység: Rudabánya (Virók 2001, DE). Lit.: Flóratérképezési adat [1]: Imola (Vojtkó András 2001). Ined.: Jákfalva: Kazai-oldal (SzP 2021). Félszáraz irtásréten. [!7689.3].

1670. Odontites lutea (L.) Clairv. - Herb.: Putnok (Zólyomi 1927, BP); Rudabányai-hegység: Rudabánya (Virók 2001, DE). Lit.: Sajókaza (HASZonITS et al. 2021). Ined.: Zádorfalva: Varjas-part (SzP 2006). Szálkaperjés réten került elő, a faj a Tornense területén ritka. [!7688.2].

1677. Rhinanthus rumelicus Velen. - Herb.: Rudabánya (Soó 1936, DE); Alsószuha: Dobostető (Virók 2012, DE). Lit.: Szuhogy (MolNÁR et al. 2018). Ined.: Alsószuha: Dobos-tető (SzP 2008), Felső-rét (SzP 2014), Feneketlen (SzP 2014); Dövény: Alsó-rét (SzP 2014), Felső-rét (SzP 2014); Felsőkelecsény: Aradvány alja (BG 2021); Izsófalva: Cseres-dủlő (BG 2021); Jákfalva: Alsó-rét (SzP 2014), Falu-rét (SzP 2014); Rudolftelep: Cseres-dűlő (BG 2021); Szuhafő: Alsó-rét (SzP 2014), Korlát-patak völgye (SzP 2021), Pető-házi-szőlő (SzP 2021), Virág-domb (SzP 2014); Zádorfalva: Bors-völgy (SzP 2009), Iván-tető (SzP 2014), Szuhavölgy (SzP 2014), Varjas-part (SzP 2021). Nedves és száraz réteken, a Rhinanthus serotinusszal átmeneti alakok is megfigyelhetők. [!7588.4], [!7688.2], [!7689.1], [!7689.2], [!7689.3], [!7790.1].

1688. Orobanche arenaria Borkh. - Lit.: Rudabányai-hegység: Szendrő (VIRóK et al. 2016). Flóratérképezési adat [1]: Felsőnyárád (Bátori Gábor 2009). Ined.: Felsőnyárád: Mestergaz, 18 tő (BG 2009). Sztyepréten. [7689.4].

1695. Orobanche reticulata Wallr. - Lit.: Kelemér (VIRóK et al. 2010). Ined.: Felsőnyárád: Aradvány (BG 2009); Szuhafő: Kis kútnál (SzP 2009). Száraz gyepekben. [7588.4], [7689.4].

1703. Orobanche lutea Baumg. - Herb.: Zádorfalva: Belterület (Virók 2005, DE). Lit.: Putnok; Szuhafő: Szuha-völgy; Trizs mellett (PENKSZA \& MALATINSZKY 2001). Ined.: Alsószuha: Feneketlen (SzP 2007), Vad-répás (SzP 2006); Ragály: Gerenda-oldal (SzP 2008), Ortványkert (SzP 2008); Szuhafő: Centu-hegy (SzP 2008), Pető-háza (SzP 2021), Pincék alja (SzP 2006); Trizs: Akasztó-bérc (SzP 2008), Eresztvény-tető (SzP 2010), Páris-völgy (SzP 2008), Rozsnyói-oldal (SzP 2006); Temető (SzP 2009); Zádorfalva: Almás (SzP 2014), Almás alja (SzP 2014), Arany-kúti-oldal (SzP 2009), Bakó (SzP 2014), Berek eleje (SzP 2006), Bütykös alja (SzP 2015), Cseres-völgy (SzP 2011), Iván-tető (SzP 2010), Nagy-kánya-fő (SzP 2011), 
Nagy-szőlő (SzP 2009), Nagy-szőlő alja (SzP 2021), Ragyás-szőlő (SzP 2010), Rakottyástető (SzP 1995), Szellő-tető (SzP 1995), Temető (SzP 2001), Templom-oldal (SzP 2009), Varjas-part (SzP 2010). Sztyepréteken. [7588.4], [7589.3], [7688.2], [7689.1].

1706. Orobanche elatior Sutton - Lit.: Flóratérképezési adatok [1]: Felsőnyárád (Szentgyörgyi Péter 2006); Gömörszőlős (Virók Viktor 2005). Ined.: Felsőnyárád: Kővágó alja (BG 2009), Mestergaz (SzP 2006); Kurityán: Határ melléke (SzP 2006), Szőlő-oldal (SzP 2006); Ragály: Gerenda-oldal (SzP 2011), Ortvány-kert (SzP 2011); Zádorfalva: Iván-tető (SzP 2009), Ragyás-szőlő (SzP 2009), Varjas-part (SzP 2005). Sztyepréteken. [!7589.3], [7688.2], [7689.4].

*1713. Utricularia vulgaris L. - Lit.: Bódva-völgy: Bódvaszilas (BoRos 1922); Cserehát: Szalonna (VIRóK et al. 2010). Ined.: Izsófalva: Alsó-réti-bányatavak (SzP 2006). Hínárnövényzetben, a későbbi években nem került elő. [!7789.2].

1728. Galium glaucum L. - Lit.: Flóratérképezési adatok [1]: Imola (Vojtkó András 2001); Kelemér (G. Farkas Tünde 2004). Ined.: Felsőnyárád: Mestergaz (SzP 2008). Sztyepréten. [!7689.4].

*1730. Galium elongatum C. Presl in J. Presl et C. Presl - Herb.: Bódva-völgy: Hidvégardó (Vojtkó 2001, BP), Szalonna (Virók 2006, DE). Lit.: Bódva-völgy: Bódvarákó, Hidvégardó (VIRóK et al. 2016). Ined.: Izsófalva: Alsó-rét (SzP 2008). Mocsárréten kis állománya került elő. A tavak és környékük rekultivációja után eltűnt. [!7789.2].

**1784. Cephalaria transsylvanica (L.) Schrad. - Ined.: Kurityán: Malom-mező (BG 2021). Partfalon. [!7689.4].

1785. Dipsacus pilosus L. - Lit.: Galyaság: Teresztenye, Tornakápolna (VIRóK et al. 2016). Flóratérképezési adat [1]: Kelemér (G. Farkas Tünde 2003). Ined.: Dubicsány: Kedves-hegy (BG 2020); Felsőkelecsény: Csörgős-patak (BG 2020); Felsőnyárád: Csörgős-patak (BG 2020); Zubogy: Csörgős-patak - falu alatti szakasz (BG 2020). Ligeterdőkben. [!7689.2], [!7689.4], [7788.2].

*1787. Dipsacus fullonum L. - Lit.: Bódva-völgy: Perkupa, Szögliget; Rudabányai-hegység: Alsótelekes, Szendrő (VIRóK et al. 2016). Ined.: Felsőkelecsény: Száraz-rét (BG 2021); Felsőnyárád: Aradvány (BG 2021). Szántóföld által határolt füzes szélén és rekultivált külfejtés területén. [!7689.2], [!7689.4].

1788. Succisa pratensis Moench - Herb.: Imola: Kerek-erdő (Virók 2001, DE). Lit.: Kurityán és Sajókaza közötti terület (TAKÁcs et al. 2016). Ined.: Ragály: Határnál (BG 2020); Szuhafö: Pető-háza (SzP 2006), Pető-házi-szőlő (SzP 2006). Kékperjés lápréteken. [!7688.2], [!7689.1].

1831. Aster amellus L. - Herb.: Trizs (Jávorka és Zólyomi 1949, BP). Lit.: Gömörszőlős; Putnok: Hegyes-tető; Sajókaza: Ráró-hegy, Szár-hegy; Zádorfalva: Rakottyás-tető (PENKSZA \& MALATINSZKY 2001, MALATINSZKY 2004); Ragály: Ortvány-kert; Szuhafő: Centu-hegy; Zádorfalva: Iván-tető, Latrány, Nagy-Szőlő-tető (MALATinsZky (2007). Ined.: Alsószuha: Feneketlen (SzP 2015), Hegyes-hegy (SzP 1995); Ragály: Ortvány-kert (SzP 1995); Sajókaza: Papszőlők (BG 2020); Szuhafő: Pálykás (SzP 2011), Pető-házi-szőlő (SzP 2009), Pincék alja (SzP 1999), Tubóka (SzP 2018); Trizs: Akasztó-bérc (SzP 2007), Comád (SzP 2011), Eresztvény-tető (SzP 2011), Rozsnyói-oldal (SzP 2012); Zádorfalva: Arany-kúti-oldal (SzP 2009), Bakó (SzP 1995), Bütykös alja (SzP 2017), Bütykös-oldal (SzP 2017), Cseres-alja (SzP 2007), Cseres-völgy (SzP 2007), Iván-tető (SzP 1995), Kis-völgy (SzP 2011), Latrány-völgy (SzP 2007), Nagy-szőlő alja (SzP 2007), Ragyás-szőlő (SzP 2007), Rakottyás-tető (SzP 1995), Varjas-part (SzP 1995). Szálkaperjés réteken, erdőszéleken kevés, de néhány nagyobb (több száz töves) állománya is előkerült. [7588.4], [7589.3], [7688.2], [!7689.1], [7689.4].

1847. Gnaphalium uliginosum L. - Lit.: Sajókaza (HASZoniTs et al. 2021). Flóratérképezési adat [1]: Szuhafő (Virók Viktor 2004). Ined.: Felsőkelecsény: Legelő (BG 2016); Felsőnyá- 
rád: Egyház megi dűlő (BG 2021), Gyökér-kúti-dűlő (BG 2021), Jákfalvi-dúlő (BG 2021), Kelecsényi-úton-aluli-dúlő (BG 2016), Kelecsényi-úton-felüli-dűlő (BG 2021). Nedves gyomtársulásokban. [7689.2], [!7689.4].

1851. Inula helenium L. - Lit.: Zádorfalva: Rakottyás-tető (PENKSZA \& MALATINSZKY 2001); Alsószuha: Felső-rét; Kelemér és Gömörszőlős között a Keleméri-patak mentén; Zádorfalva: Rakottyás-völgy, Rakottyás-tető (MALATıNSZKY 2004); Alsószuha: Gyámol-völgy; Gömörszőlős; Kelemér; Ragály és Zubogy közötti terület (Ragály: Hosszak-dúlő); Rudabánya: Hársashegy (Agyagos-oldal); Szuhafő (Zádorfalva): Latrány-völgy; Zádorfalva: Bors-völgy; Zádorfalva és Alsószuha között a Szuha mente (Zádorfalva: Szuha-völgy); Zádorfalva és Kelemér közötti terület (VIRóK et al. 2004); Alsószuha: Dobos-dűlő, Felső-rét; Gömörszőlős; Kelemér; Serényfalva; Zádorfalva: Bors-völgy, Latrány-völgy, Mocsolyás-völgy, Ragyás-szőlő, Rakottyás-kút, Rakottyás-völgy (MALATINSZKY 2007). Ined.: Alsószuha: Felső-rét (SzP 1999), Feneketlen (SzP 2015), Hegyes-hegy (SzP 2021), Kánya-völgy (SzP 2015), Lác-oldal (SzP 2015), Lengyel-oldal (SzP 2015), Megye-berek (SzP 2015), Ritka-dűlő, 5 tő (SzP 2010), Ritka-oldal, 50 tő (SzP 2011), Vad-répás (SzP 2017); Dövény: Belterület, 1 tő (SzP 2016); Felsőkelecsény: Száraz-rét (BG 2021); Izsófalva: Kavicsos (SzP 2021); Kurityán: Szuha, 1 tő (BG 2020); Ragály: Ádám-völgy (SzP 2021), Barom-szer, 35 tő (SzP 2010), Csornok, 150 tő (SzP 2006), Isten harasztja (SzP 2021), Pénzvermek (SzP 2021), Vasas alja (SzP 2012); Szuhafő: Alsó-rét, 25 tő (SzP 2005), Pálykás (SzP 2021), Virág-domb (SzP 2017); Trizs: Eresztvény-tető, 80 tő (SzP 2010), Forrás-völgy (SzP 2021), Parcellás (SzP 2021), Párisvölgy (SzP 2019); Zádorfalva: Almás (SzP 2015), Arany-kúti-oldal, 1 tő (SzP 2011), Bakó (SzP 2015), Berek eleje (SzP 2005), Cseres alja (SzP 2015), Cseres-völgy (SzP 2013), Csomós alja (SzP 2015), Dobos-völgy, 4 tő (SzP 2004), Gyámol, 25 tő (SzP 2005), Iván-tető (SzP 2018), Kis-erdő-tető, 2 tő (SzP 2011), Nagy-szőlő alja, 53 tő elszórtan a földút mellett, a Rakottyás-völgy felöl terjed (SzP 2011), Petrecz (SzP 2021), Pót-haraszt (SzP 2015), Rakotytyás-tető, 5 tő (SzP 1996), Rakottyás-völgy (SzP 1996), Templom-oldal (SzP 2021), Varjaspart (SzP 2018); Zubogy: Bodon alja (BG 2021), Fekete-föld, 1 tő (SzP 2009). Magaskórósokban, réteken, főleg szárzúzások után terjed, Zádorfalva környékén (Latrány-völgy, Rakottyás-völgy, Szuha-völgy) sok száz töves állományok fordulnak elő. [7588.4], [!7589.3], [7688.2], [7689.1], [7689.2], [!7689.3], [!7689.4].

1866. Bidens cernua L. - Herb.: Bódva-völgy: Edelény (Budai 1906, BP). Lit.: Kelemér (VIRóK et al. 2004). Ined.: Felsőnyárád: Kelecsényi-úton-aluli-dűlő (BG 2020); Kurityán: Határ melléke, 3 tő (SzP 2006). Nedves gyomtársulásokban. [!7689.4].

*1882. Xanthium saccharatum Wallr. - Herb.: Rudabányai-hegység: Alsótelekes (Virók 2015, DE); Bódva-völgy: Hidvégardó (Virók 2015, DE). Lit.: Sajó-völgy: Sajószentpéter (VIRóK et al. 2004). Rudabányai-hegység: Rudabánya: (VIRóK et al. 2016). Ined.: Zádorfalva: Bütykös alja (SzP 2011); Iván-tető (SzP 2011). Vadszórók mellett. [!7588.4], [!7688.2].

1929. Artemisia pontica L. - Lit.: Sajókaza (PENKSZA \& MALATINSZKY 2001); Alsószuha: Virágos-oldal (Hegyes-hegy); Dövény: Pencs-oldal, Tukó-hegy; Szuhafő: Pető-háza (MALATINSZKY 2007). Ined.: Felsőnyárád: Jákfalvi-dűlő (BG 2021), Ốr-hegy (BG 2019); Izsófalva: Cseres-dűlő (BG 2021), Gede-tető (SzP 2011), Kavicsos (SzP 2011); Kurityán: Gyümölcsösoldal (SzP 2011), Susa-tető (SzP 2011), Szőlő-oldal (BG 2020); Zádorfalva: Ragyás-szőlő (SzP 2011). Sztyepréteken. [7689.4], [7789.2], [!7790.1].

1945. Senecio viscosus L. - Lit.: Kelemér (VIRÓK \& FARKAS 2007). Ined.: Alsószuha: Virágoldal (SzP 2021). Vágásterületen. [!7689.1].

1946. Senecio vernalis Waldst. et Kit. - Lit.: Sajó-völgy: Sajóivánka (HASZonits et al. 2021). Flóratérképezési adatok [1]: Felsőnyárád (Anonym 2005); Szuhafő (Virók Viktor 2004). Ined.: Dövény: Alsó-rét (SzP 2021). Parlagon. [!7689.3].

1961. Carlina acaulis L. - Herb.: Putnok (Zólyomi 1927, BP). Lit.: Putnok (ZóLYomi 1929); Trizstől északra fekvő dombokon; Zádorfalva: Cseres-völgy mellett, Rakottyás-tető (Arany- 
kúti-oldal) (PenksZA \& MALATinSZKY 2001, MALATinsZKY 2004); Ragály: Ortvány-kert; Zádorfalva: Iván-tető (MALATINSZKY 2007). Ined.: Ragály: Ortvány-kert (SzP 1995); Trizs: Rozsnyói-oldal (SzP 2006); Zádorfalva: Almás (SzP 2019), Berek eleje (SzP 2009), Iván-tető (SzP 1996), Nagy-szőlő alja (SzP 2010), Rakottyás-tető (SzP 1995), Szellő-tető (SzP 2001), Varjas-part (SzP 1996). Száraz gyepekben találtuk, Zádorfalva környéki sok száz töves állományai az utóbbi években szinte teljesen eltűntek. [7588.4], [7589.3], [7688.2].

1971. Jurinea mollis (L.) Rchb. - Lit.: Trizs mellett (PENKSZA \& MALATINSZKY 2001); Szuhafő: Centu-hegy, Pincék alja; Zádorfalva: Iván-tető (MALATINSZKY 2007). Ined.: Szuhafő: Kis kútnál (SzP 2009), Pálykás (SzP 2015), Pincék alja (SzP 1996), Virág-domb (SzP 1996); Trizs: Akasztó-bérc (SzP 2008), Comád (SzP 2011), Eresztvény-tető (SzP 2009), Páris-völgy (SzP 2011), Rozsnyói-oldal (SzP 2006), Vermek-oldal (SzP 2011); Zádorfalva: Bütykös alja (SzP 2008), Nagy-szőlő alja (SzP 2011). A faj a Putnoki-dombságban ritka, csak az északi részek sztyeprétjein találtuk, legnagyobb (sok száz töves) állományai Trizs környékén fordulnak eló. [7588.4], [7589.3], [7688.2].

1987. Cirsium pannonicum (L.f.) Link - Herb.: Trizs (Jávorka és Zólyomi 1949, BP). Lit.: Imola: Kavacsos-part (BUDAY 1979); Gömörszőlős; Zádorfalva: Iván-tető, Ragyás-szőlő (MALATINSZKY 2007). Ined.: Alsószuha: Feneketlen (SzP 2015), Hegyes-hegy (SzP 2015), Kányafő (SzP 2010), Lác-oldal (SzP 2015), Vad-répás (SzP 2015); Felsőnyárád: Mestergaz (BG 2012); Izsófalva: Cseres-dűlő (BG 2021), Kavicsos (SzP 2021); Ragály: Gerenda-oldal (SzP 2008), Ortvány-kert (SzP 1995); Rudabánya: Fekete-parlag (BG 2017); Szuhafő: Centuhegy (SzP 2009), Pálykás (SzP 2010), Pető-háza (SzP 2010), Pető-házi-szőlő (SzP 2006), Pincék alja (SzP 2000), Virág-domb (SzP 2009); Trizs: Eresztvény-tető (SzP 2009); Zádorfalva: Bütykös alja (SzP 2015), Cseres alja (SzP 2015), Cseres-völgy (SzP 2009), Latrányvölgy (SzP 2009), Nagy-szőlő (SzP 2009), Nagy-szőlő alja (SzP 2021), Rakottyás-tető (SzP 2015), Szellő-tető (SzP 2011), Varjas-part (SzP 2006); Zubogy: Suba-oldal (BG 2017). Szálkaperjés gyepekben találtuk, az utóbbi években több új helyen is előkerült. [!7588.4], [7589.3], [7688.2], [!7689.1], [!7689.2], [!7689.4], [!7790.1].

2000. Centaurea indurata Janka - Lit.: Putnok: Hegyes-tető (PenksZa \& MALATinszky 2001); Alsószuha (Molnár et al. 2018). Ined.: Alsószuha: Kánya-völgy (SzP 2021); Dövény: Felsőrét (SzP 2021), Gödör-köz-dűlő (SzP 2021); Kurityán: Szőlő-oldal (BG 2020); Zádorfalva: Varjas-part (SzP 2021). Száraz és félszáraz réteken. [!7688.2], [7689.1], [!7689.4].

2005. Centaurea triumfettii All. - Herb.: Putnok (Zólyomi 1926, BP). Lit.: Rudabánya (Soó et al. 1943); Gömörszőlős; Kelemér (FARKAs 2010). Ined.: Alsószuha: Feneketlen (BG 2016), Hegyes-hegy (SzP 1996), Kánya-fő (SzP 2012), Vad-répás (SzP 1995); Felsőnyárád: Mestergaz (SzP 1994); Ragály: Gerenda-oldal (BG 2015), Ortvány-kert (SzP 1995); Rudolftelep: Homonc (BG 2016); Sajógalgóc: Padi-földek (BG 2017); Szuhafő: Pálykás (SzP 2009), Petőházi-szőlő (SzP 1998), Pincék alja (SzP 2006), Virág-domb (SzP 2006), Zsilip-tető (SzP 2009); Trizs: Akasztó-bérc (SzP 2008), Comád (SzP 2010), Eresztvény-tető (SzP 2009), Rozsnyói-oldal (SzP 2009); Zádorfalva: Berek eleje (SzP 2006), Bütykös alja (SzP 2009), Cseres-völgy (SzP 2009), Iván-tető (SzP 2009), Kis-völgy (SzP 2021), Latrány-völgy (SzP 2012), Nagy-szőlő (SzP 1997), Ragyás-szőlő (SzP 1996), Szellő-tető (SzP 1995), Temető (SzP 2021), Varjas-part (SzP 2005). Sztyepréteken, felhagyott szőlőkben csökkenő állományban került elő. [!7588.4], [!7589.3], [7688.2], [!7689.1], [7689.4], [7690.3], [!7789.1].

*2026. Scorzonera purpurea L. - Lit.: Galyaság: Perkupa, Szőlősardó, Varbóc (SzmORAD 2000); Galyaság: Szőlősardó (DÚBRAKOVÁ-MichÁLKOVA et al. 2008); Galyaság: Szőlősardó, Varbóc (VARGÁNÉ SIPOS \& VARGA 2014); Rudabányai-hegység: Alsótelekes, Szendrő; Galyaság: Égerszög, Szőlősardó, Teresztenye, Tornakápolna (VIRóK et al. 2016). Ined.: Rudolftelep: Cseres-dúlő (BG 2016), Cseres-szőlő (BG 2016). Sztyepréteken. [!7690.3].

2037. Sonchus palustris L. - Lit.: Ragály és Zubogy között (BÁNKÚTI 1994); Kelemér; Rudabánya; Serényfalva; Trizs; Zádorfalva (BÁNKÚTI \& VojTKó 1995); Trizs (SOMLYAY \& LőKös 
1999); Zubogy: Csörgős-patak (PENKSZA et al. 1999/2000); Dövény: Alsó-rét, Felső-rét; Gömörszőlős; Imola: Leléte-völgy; Kelemér; Ragály: Csörgős-patak mellett; Serényfalva; Sajógalgóc; Sajókaza; Szuhafő: Korlát-patak mellett; Zádorfalva: Bors-völgy, Iván-tető, Latrányvölgy (MALATinszkY 2007). Ined.: Alsószuha: Alsó-rét (SzP 2001), Bakócz (SzP 2006), Dobos-tető (SzP 2008), Felső-rét (SzP 2006), Feneketlen (SzP 2015), Gyámol-völgy (SzP 2015), Hegyes-hegy (SzP 2015), Jegenye-völgy (SzP 2005), Juhászat - Szuha (SzP 2006), Kánya-völgy (SzP 2015), Külső-rónya (SzP 2001), Ritka-dűlő (SzP 2006), Szuha (SzP 2001); Dövény: Belterület (SzP 2005), Belterület, Szil-patak (SzP 2005), Felső-rét (SzP 2005), Gödör-köz-dűlő (SzP 2010), Kerek-föld (SzP 2011), Kötél-föld (SzP 2005), Tófenék-Szuha (SzP 2006); Felsőkelecsény: Aradvány (SzP 2009), Aradvány alja (SzP 2009), Bozsdár (SzP 2005), Bozsdár-erdő (SzP 2006), Kelecsényi-Nagy-hegy (SzP 2007); Felsőnyárád: Belterület, Szuha (SzP 2001), Kelecsényi-úton-aluli-dűlő (SzP 2006), Kelecsényi-úton-felüli-dűlő (SzP 2001); Imola: Zúgó-völgy (SzP 2006); Izsófalva: Alsó-rét (SzP 2006), Kállói-tag (SzP 2006), Kovácsok rétje (SzP 2008), Szuha (SzP 2006); Jákfalva: Alsó-rét (SzP 2006), Falu-rét (SzP 2006), Gyökér-kúti-rét (SzP 2001), Kender-földek (SzP 2001), Köteles (SzP 2015), Köteles alja (SzP 2010), Süveges alja (SzP 2006); Kurityán: Hencel-szög (SzP 2009), Kurityántelepi-bányató (SzP 2006), Szuha (SzP 2006); Ormosbánya: Kavicsos (SzP 2006), Kavicsos Ormos-patak (SzP 2006), Ormos alja (SzP 2010); Ragály: Batyik-völgy (SzP 2010), Csikó-rét (SzP 2009), Csornok (SzP 2007), Ortvány-kert (SzP 2004), Rózsás (SzP 2010), Tamáska (SzP 2010); Rudabánya: Gyertyános alja (SzP 2010), Rudabányai-völgy (SzP 2010); Szuhafő: Alsó-rét (SzP 2006), Centu-hegy (SzP 2012), Korlát-patak völgye (SzP 2001), Pálykás (SzP 2009), Pető-háza (SzP 2006), Pető-házi-szőlő (SzP 2012), Pincék alja (SzP 2012); Trizs: Csörgős-lapos (SzP 2006), Kender-földek (SzP 2011); Zádorfalva: Arany-kúti-oldal (SzP 2009), Berek eleje (SzP 2005), Cseres-völgy (SzP 2009), Csomós alja (SzP 2012), Dobos-völgy (SzP 2010), Gyámol (SzP 2010), Iván-tető (SzP 2010), Kis-erdő-tető (SzP 2012), Mocsolyás-völgy (SzP 2014), Rakottyás-völgy (SzP 2007), Szellő-tető (SzP 2009), Szuhavölgy (SzP 2007), Szuhai-tag (SzP 2010), Templom-oldal (SzP 2009), Varjas-part (SzP 2009), Varjas-völgy (SzP 2005); Zubogy: Belterület (BG 2021), Belterület, Csörgős-patak (SzP 2006), Bodon alja (SzP 2009), Borsó-szer (SzP 2005), Dövény-szögi-dúlő (SzP 2006), Fekete-föld (SzP 2009), Meskó-rét (SzP 2001), Szuhucer (SzP 2005). Patakok melletti és lápi magaskórósokban, de félszáraz gyepekben és erdőszegélyeken is előfordul, legnagyobb állományai Zádorfalva környékén találhatók. [7588.4], [7589.3], [7688.2], [7689.1], [7689.2], [7689.3], [7689.4], [!7789.2].

*2039. Lactuca perennis L. - Herb.: Galyaság: Perkupa (Hulják 1937, BP); Rudabányaihegység: Felsőtelekes (Gulyás P. 2005, BP). Lit.: A Gömör-Tornai-karszton nem ritka. (VIRóK et al. 2016). Ined.: Dubicsány: Gyöngyös-hegy (BG 2017); Sajógalgóc: Nagy-hegy (BG 2017); Sajókaza: Csüre (BG 2016). Cserjés szegélyek, csupasz talajfelszínen. [7788.2], [!7789.1].

2041. Lactuca quercina L. - Lit.: Flóratérképezési adat [1]: Imola (Vojtkó András 2001). Ined.: Felsőnyárád: Jákfalvi-dűlő (BG 2021). Holtmeder-maradvány szélén. [!7689.4].

2054. Crepis rhoeadifolia M. Bieb. - Herb.: Rudabányai-hegység: Rudabánya (Virók 2001, DE). Lit.: Flóratérképezési adat [1]: Gömörszőlős (G. Farkas Tünde 2003). Ined.: Zubogy: Suba-oldal (BG 2021). Gyomtársulásban. [!7689.1].

2056. Crepis setosa Haller - Lit.: Zádorfalva (MoLnÁR et al. 2017). Ined.: Dövény: Alsó-rét (SzP 2021); Ragály: Barom-szer (SzP 2021). Gyomtársulásokban. [!7589.3], [!7689.3].

*2125. Alisma lanceolatum With. - Lit.: Bódva-völgy: Bódvalenke, Bódvarákó, Hidvégardó, Perkupa, Szalonna, Szögliget (VIRóK et al. 2016). Ined.: Kurityán: Henczel-szög (SzP 2011). Bányató szélvizében. [!7689.4].

2127. Butomus umbellatus L. - Lit.: Flóratérképezési adatok [1]: Felsőnyárád (Anonym 2005); Jákfalva; Zubogy (Malatinszky Ákos és Penksza Károly 2003). Ined.: Felsőkelecsény: 
Bozsdár (SzP 2006), Száraz-rét (BG 2020); Felsőnyárád: Csörgős-patak (BG 2018), Szuha (SzP 2006); Izsófalva: Kavicsosi-bányató (SzP 2006), Szuha (SzP 2006); Kurityán: Feketevölgy (BG 2021), Kurityáni-bányató (SzP 2006), Kurityántelepi-bányató (SzP 2006), Szuha (SzP 2006). Vízpartokon, mocsarakban, árkokban. [!7689.2], [7689.4], [7789.2].

*2131. Elodea canadensis Michx. - Herb.: Múcsony: Sajó-völgy (Virók 2003, DE). Lit.: Sajóvölgy: Sajókaza (MALATINSZKY \& PENKSZA 2002). Ined.: Izsófalva: Alsó-réti-bányatavak (SzP 2006). Hínárnövényzetben élt, a tavak rekultivációja után eltűnt. [!7789.2].

*2146. Hemerocallis fulva L. - Lit.: Rudabányai-hegység: Rudabánya; Bódva-völgy: Szögliget (VIRóK et al. 2016). Ined.: Felsőkelecsény: Aradvány (BG 2021); Felsőnyárád: Némethtag (BG 2020); Kurityán: Henczel-szög (SzP 2012); Sajó-völgy: Múcsony: Szuha-zugi-földek (SzP 2012). Réteken elvadulva. [!7689.2], [!7689.4], [!7790.1].

2153. Ornithogalum boucheanum (Kunth) Asch. - Lit.: Serényfalva (TAKÁCS et al. 2016); Gömörszőlős (HASzonITs et al. 2021). Ined.: Felsőkelecsény: Bozsdár-erdő (BG 2021); Kurityán: Kurityán-tető (SzP 2006); Múcsony: Meleg-oldal (SzP 2008); Sajógalgóc: Nagy-pallag (BG 2017), Padi-földek (BG 2017). Akácosokban, mezsgyéken. [!7689.2], [7689.4], [!7789.1], [7790.1].

2155. Ornithogalum brevistylum Wolfner - Herb.: Ragály (Nagy 2014, DE). Lit.: Szuhafó: Puha-völgy; Trizs (SomlYAY és LőKös 1999); Gömörszőlős; Zádorfalva: Mocsolyás-völgy (Penksza \& Malatinszky 2001); Alsószuha: Rónya-puszta, Vad-répás; Dövény mellett; Felsőnyárád: Kővágó; Gömörszőlős; Imola: Leléte-völgy; Jákfalva: Süveges-oldal, Szőlő-bérc, Tövises-völgy; Kelemér; Zádorfalva: Bors-völgy, Rakottyás-tető (MALATinszkY 2007); Gömörszőlős; Kelemér (FARKAS 2010); Imola: Temető; Kánó: Temető; Zádorfalva: Temető (MolnÁr V. \& LöKI 2018); Sajókaza (Molnár et al. 2019). Ined.: Alsószuha: Alsó-rét (SzP 2006), Bakócz (SzP 2006), Feneketlen (SzP 2009), Gyámol-völgy (SzP 2009), Hegyes-hegy (SzP 1996), Kánya-fő (SzP 2015), Kánya-völgy (SzP 2009), Kis-kánya-fő (SzP 2009), Külsőrónya (SzP 2010), Lác-oldal (SzP 2018), Lengyel-oldal (SzP 2011), Megye-berek (SzP 2021), Ritka-dűlő (SzP 2006), Szilas-oldal (SzP 2020), Temető (SzP 2021), Vad-répás (SzP 1995); Felsőkelecsény: Aradvány alja (BG 2017), Nyárádi-dűlő (SzP 2001); Felsőnyárád: Kővágó alja (BG 2007), Mestergaz (SzP 1994), Őr-hegy (SzP 1994), Válós-út alja (BG 2005); Imola: Puszta-szőlő (SzP 1996); Izsófalva: Cseres-dúlő (SzP 1994), Gede-tető (SzP 1994), Kavicsos (SzP 2006), Koplaló (SzP 2013), Sưrű-tető (SzP 2013); Jákfalva: Meleg-oldal (SzP 2017); Kurityán: Belterület (BG 2013), Hársas-erdő (BG 2010), Koritó (SzP 1994), Kurityán-tető (SzP 1994), Malom-mező (SzP 1994), Susa-tető (SzP 1994), Szőlő-oldal (SzP 1994); Ragály: Barom-szer (SzP 2010), Batyik-völgy (SzP 2010), Csornok (SzP 2010), Fagyalas (SzP 2010), Gerenda-oldal (SzP 2009), Kis-kánya-rét (SzP 2009), Ortvány-kert (SzP 1996), Pénzvermek (SzP 2009); Rudolftelep: Császtai-bércrejáró (BG 2017), Cseres-dűlő (BG 2013), Edelényi-legelő (BG 2017), Felső-rét (SzP 1997); Sajógalgóc: Nagy-hegy (BG 2017), Padi-földek (BG 2017); Sajókaza: Nagy-domonyó (BG 2017); Szuhafó: Alsó-rét (SzP 2009), Centu-hegy (SzP 2009), Kis kútnál (SzP 2009), Korlát-patak-völgye (SzP 2015), Pálykás (SzP 2010), Pető-háza (SzP 1996), Pető-házi-szőlő (SzP 2010), Pincék alja (SzP 2008), Temető (SzP 2021), Virág-domb (SzP 2006); Szuhakálló: Hosszú-horvát (SzP 2011), Meleg-oldal (BG 2017), Nyomás (SzP 1994); Trizs: Akasztó-bérc (SzP 2010), Comád (SzP 2013), Eresztvény-tető (SzP 2009), Forrás-völgy (SzP 2019), Rozsnyói-oldal (SzP 2013); Zádorfalva: Almás (SzP 2010), Arany-kúti-oldal (SzP 2009), Bakó (SzP 1996), Berek eleje (SzP 1996), Bütykös alja (SzP 2012), Cseres alja (SzP 1998), Cseres-völgy (SzP 2009), Csomós alja (SzP 2009), Iván-tető (SzP 2009), Kiserdő-tető (SzP 2009), Latrány-völgy (SzP 2009), Nagy-kánya-fő (SzP 2009), Nagy-szőlő (SzP 1996), Nagy-szőlő alja (SzP 1996), Petrecz (SzP 2015), Ragyás-szőlő (SzP 2006), Rakottyás-tető (SzP 1995), Szellő-tető (SzP 2006), Szuha-völgy (SzP 2006), Temető (SzP 2014), Templom-oldal (SzP 2009), Varjas-part (SzP 1996), Varjas-völgy (SzP 2009); Zubogy: Bodon alja (SzP 1996), Suba-oldal (BG 2016), 
Szuhucer (SzP 2001). Különböző füves élőhelyeken (száraz gyepek, sztyeprétek, mezsgyék), gyakori, helyenként több száz töves állományok is találhatók. [7588.4], [7589.3], [7688.2], [7689.1], [!7689.2], [7689.3], [7689.4], [!7690.3], [7789.1], [7789.2], [!7790.1].

2162. Scilla kladnii Schur - Lit.: Alsószuha: Bakóc-völgy (MALATINSZKY 2007). Ined.: Alsószuha: Bakóc-völgy (SzP 2001), Határ-völgy (SzP 2010), Kakas-vári-oldal (SzP 2001), Kocka-lápa-bérc (SzP 2010), Putnoki-oldal (SzP 2013); Dövény: Határ-völgy (SzP 2010), Temető (SzP 2002), Varcsó (SzP 2006), Varcsó-völgy (SzP 2002); Felsőnyárád: Kis-erdő (BG 2010), Nyárádi-oldal (BG 2014); Szuhafő: Szuha-völgy (SzP 2017); Zádorfalva: Ragyásszőlő (SzP 1999); Zubogy: Doma alja (BG 2015). Gyertyános-tölgyesekben, temetőben, cserjésekben, égerligetekben, felhagyott szőlőben. Alsószuha környékén nagy állományok fordulnak elő. [!7588.4], [!7688.2], [7689.1], [!7689.3], [!7689.4].

2172. Allium sphaerocephalon L. - Lit.: Flóratérképezési adat [1]: Felsőnyárád (Anonym 2005). Ined.: Felsőnyárád: Kővágó alja (SzP 1994). Sztyepréten. [7689.4].

2186. Allium angulosum L. - Herb.: Dövény: Alsó-rét (Virók 2003, DE). Lit.: Flóratérképezési adatok [1]: Jákfalva; Zubogy (Malatinszky Ákos és Penksza Károly 2003). Ined.: Alsószuha: Alsó-rét, 500 tő (SzP 2000); Dövény: Alsó-rét, 300 tő (SzP 1999), Felső-rét, 500 tő (SzP 1998); Felsőkelecsény: Nyárádi-dúlő, 5 tő (BG 2020); Jákfalva: Alsó-rét, 500 tő (SzP 2006), Kender-földek, 7 tő (2011); Kánó: Nagy-völgy (BG 2016); Ragály: Határnál, 1 tő (SzP 2006). Nedves réteken változó számban fordul elő. [!7589.4], [7689.1], [7689.2], [7689.3].

2188. Allium oleraceum L. - Lit.: Trizs: Hideg-víz-völgy (BUDAY 1979); Flóratérképezési adat [1]: Szuhafő (Virók Viktor 2004). Ined.: Felsőnyárád: Mestergaz (BG 2021); Kurityán: Ormos-hegy (SzP 2015). Erdőszéleken. [!7689.4].

2190. Allium flavum L. - Lit.: Flóratérképezési adat [1]: Gömörszőlős (G. Farkas Tünde 2003). Ined.: Dubicsány: Galgóci-oldal (BG 2020), Látó-oldal (BG 2020). Vulkanikus sziklakibúvások körül. [!7789.1].

2193. Maianthemum bifolium (L.) F.W. Schmidt - Herb.: Szuhafő: Gyertyános (Virók 2003, DE). Lit.: Szuhafő: Szuha-völgy (PENKSZA \& SomlYaY 1999); Gömörszőlős (FARKAS 2010); Alsószuha: Bakóc-völgy; Felsőnyárád: Kővágó (MolNár et al. 2018). Ined.: Sajógalgóc: Hársaslapos (BG 2017); Szuhafő: Pető-háza (SzP 2009), Pető-házi-szőlő (SzP 2010); Zádorfalva: Iván-tető (SzP 2015). Árnyas, üde erdőkben. [7688.2], [!7689.3].

2199. Paris quadrifolia L. - Lit.: Szuhafó: Szuha-völgy (PENKSZA \& SomlYAY 1999); Alsószuha: Bakóc-völgy; Gömörszőlős; Imola mellett (Penksza \& MALATinszKY 2001); Serényfalva; Trizs: Bagoly-vágás (VIRóK et al. 2004); Kelemér (FARKAS 2010). Ined.: Szuhafő: Pető-háza (SzP 2011), Pető-házi-szőlő (SzP 2015). Gyertyános-tölgyesekben. [7688.2].

*2202. Potamogeton pectinatus L. - Herb.: Bódva-völgy: Edelény (Budai 1906, BP). Lit.: Bódva-völgy: Komjáti, Perkupa, Szögliget; Galyaság: Szőlősardó; Rudabányai-hegység: Felsőtelekes, Rudabánya (VIRóK et al. 2016); Sajó-völgy: Sajószentpéter (VIRóK et al. 2010). Ined.: Izsófalva: Alsó-réti-bányatavak (SzP 2005), Kállói-tag (SzP 2011). Hínárnövényzetben. A tavak rekultivációja után eltűnt. [!7789.2].

*2208. Potamogeton berchtoldii Fieber - Herb.: Bódva-völgy: Perkupa (Virók 2005, DE). Lit.: Bódva-völgy: Perkupa (VIRóK \& FARKAS 2007, VIRóK et al. 2016); Galyaság: Szőlősardó (VIRóK et al. 2010); Sajó-völgy: Sajókaza, Sajóvelezd (MALATinSZKY \& PenKSZA 2002), Sajóvölgy: Sajószentpéter (VIRóK et al. 2010). Ined.: Izsófalva: Kavicsosi-bányató (SzP 2007). A tó sekély szélvizében. [!7689.4].

2209. Potamogeton crispus L. - Lit.: Flóratérképezési adat [1]: Felsőnyárád (Anonym 2005). Ined.: Felsőnyárád: Belterület, Szuha (SzP 2001), Fekete-völgy (SzP 2021), Mestergaz (BG 2018); Izsófalva: Alsó-réti-bányatavak (SzP 2006), Alsó-rét csatorna (SzP 2006), Kavicsosi-bányató (SzP 2006), Szuha (SzP 2006); Kurityán: Kurityáni-bányató (SzP 2006); Ormosbánya: Felső-bányató (SzP 2006), Gyikos-tó (SzP 2006). Hínártársulásokban. [7689.4], [!7789.2]. 
*2212. Potamogeton lucens L. - Lit.: Bódva-völgy: Bódvalenke (PENKSZA \& MALATINSZKY 2010); Sajó-völgy: Sajóvelezd (MALATinszkY \& PENKSZa 2002). Ined.: Izsófalva: Alsó-rétibányatavak (SzP 2006). Hínárnövényzetben. A tavak rekultivációja után eltűnt. [!7789.2].

*2216. Potamogeton nodosus Poir. - Herb.: Rudabányai-hegység: Rudabánya (Virók 2016, DE); Sajó-völgy: Múcsony: Szuha (Virók 2003, DE). Lit.: Bódva-völgy: Szögliget, Galyaság: Szőlősardó (VIRóK et al. 2016); Sajó-völgy: Sajószentpéter (VIRóK et al. 2010). Ined.: Izsófalva: Alsó-réti-bányatavak (SzP 2005), József-oldal (SzP 2011), Kállói-tag (SzP 2005), Mákvölgyi-bánya (SzP 2021), Szuha (SzP 2011); Ragály: Csornok (SzP 2021). Hínárnövényzetben. [!7589.3], [!7690.3], [!7789.2].

*2218. Zannichellia palustris L. - Herb.: Szalonnai-hegység: Martonyi (Boros 1926, BP). Lit.: Bódva-völgy: Szalonna (VIRóK \& FARKAS 2007); Jósvafői-karszt: Aggtelek (VIRóK et al. 2004). Ined.: Izsófalva: Alsó-rét csatorna (SzP 2011), Kavicsosi-bányató (SzP 2006). Hínárnövényzetben, az utóbbi években nem került elő. [!7789.2].

2227. Gagea villosa (M. Bieb.) Duby - Lit.: Zádorfalva: Temető (TAKÁCS et al. 2016). Ined.: Felsőnyárád: Kővágó (BG 2021). Cseres-tölgyesben. [!7689.4].

2235. Lilium martagon L. - Lit.: Gömörszőlős (PENKSZA \& MALATINSZKY 2001); Alsószuha: Bakóc-völgy; Szuhafő: Pincék alja; Zádorfalva: Rakottyás-tető (MALATinszKY 2007); Gömörszőlős; Kelemér; Szuhafő: Pető-háza (FARKAS 2010). Ined.: Alsószuha: Határ-völgy (SzP 2013), Hegyes-hegy (SzP 2021); Felsőkelecsény: Szakáll-hegy (BG 2012), Tövises-völgy (BG 2014); Felsőnyárád: Kis-erdő (BG 2014), Kővágó (SzP 1999); Kurityán: Ormos-hegy (SzP 2015); Szuhafő: Kerék-kötő (SzP 2011), Pető-háza (SzP 1996), Pető-házi-szőlő (SzP 2006); Zádorfalva: Iván-tető (SzP 2010), Kis-völgy (SzP 2014), Nagy-szőlő-tető (SzP 2014), Varjas-part (SzP 2010). A faj a Putnoki-dombságban ritka, gyertyános-tölgyesekben, erdőszéleken és kaszálókon néhány töves állományait találtuk. [7588.4], [7688.2], [7689.1], [!7689.2], [7689.4].

*2250. Sisyrinchium bermudiana Mill. s. l. - Herb.: Aggteleki Fedett-karszt: Aggtelek (Virók 2003, 2005, DE). Lit.: Aggteleki Fedett-karszt: Aggtelek (VIRóK et al. 2004, FARKAS 2010, VIRóк et al. 2016). Ined.: Zádorfalva: Szuha-völgy (SzP 2021). Nedves réten került elő kb. 20 töves állománya, eredete ismeretlen. [!7688.2].

2254. Iris sibirica L. - Lit.: Dövény: Felső-rét; Dövény és Jákfalva között az Alsó-rét (MALATINSZKY 2004); Dövény: Alsó-rét, Belterület, Felső-rét, sportpálya környékén (Alsó-rét); Jákfalva: Alsó-rét, a település és a Szuha között (Falu-rét) (MALATINSZKY 2007). Ined.: Alsószuha: Bakócz, egy nagyobb folt (SzP 2005); Dövény: Alsó-rét, egy nagyobb és két kisebb folt (SzP 1999), Felső-rét (SzP 1991); Jákfalva: Alsó-rét, nagy tömegben (SzP 1999), Falurét (SzP 2005). Nedves réteken, az utóbbi években visszaszorulóban. [7689.1], [7689.3].

2259. Iris aphylla L. subsp. hungarica (Waldst. et Kit.) Hegi - Lit.: Putnok: Hegyes-tető (Penksza et al. 1999/2000, PenkSZA \& MaLatinszky 2001, Malatinszky 2004); Dubicsány; Kurityán: Kurityán-tető; Sajókaza (MALATinszKY \& ÁDÁm 2012); Sajókaza (TAKÁCS et. al. 2016); Imola: Temető; Zádorfalva: Temető (MolnáR V. \& LöKI 2018). Ined.: Kurityán: Szőlőoldal (SzP 2001); Putnok: Nagy-kő (BG 2019); Zádorfalva: Temető (SzP 1999). Sztyepréteken, sziklaormon. [7688.2], [7688.4], [7689.4].

2260. Iris variegata L. - Lit:: Putnok (HuljÁK 1926); Putnok; Sajókaza (PenksZa \& MALATINSZKY 2001); Alsószuha: Virágos-oldal (Hegyes-hegy) (MALATINSZKY 2007); Sajógalgóc (MALATINSZKY \& ÁDÁM 2012). Ined.: Kurityán: Hársas-erdő (SzP 1993); Kurityán-tető (SzP 1993); Zádorfalva: Temető (SzP 2002). Sztyepréteken, szálkaperjés gyepekben, erdőszegélyeken találtuk, a területen ritka. [!7688.2], [7689.4].

2341. Sclerochloa dura (L.) P. Beauv. - Lit.: Kelemér; Sajógalgóc; Sajókaza (HASZonits et al. 2021). Ined.: Felsőkelecsény: Aradvány (BG 2021); Kurityán: Belterület (BG 2021), Feketevölgy (BG 2021); Rudolftelep: Cseres-dűlő (BG 2021). Száraz, taposott területeken. [!7689.2], [!7689.4], [!7690.3]. 
2356. Melica transsylvanica Schur - Lit.: Flóratérképezési adat [1]: Felsőnyárád (Anonym 2005). Ined.: Jákfalva: Meleg-oldal (BG 2021); Múcsony: Cseres-szőlő (BG 2021). Napos, meleg felhagyott szőlőkben, erdőszegélyen. [!7689.3], [!7790.1].

*2360. Melica picta K. Koch - Lit.: Rudabányai-hegység: Alsótelekes, Szendrő (VIRóK et. al. 2016). Ined.: Felsőnyárád: Mestergaz (BG 2021); Kurityán: Nyárádi-oldal (BG 2021). Cseres-tölgyesekben. [!7689.4]

2394. Elymus elongatus (Host) Runemark - Lit.: Felsőnyárád (KIRÁLY \& KIRÁLY 2018). Ined.: Felsőnyárád: Mestergaz (BG 2021); Kurityán: Susa-tető, 1 tő (BG 2021). Gyomos parlagon, gyomos terület melletti földút szélén. Eredete ismeretlen, Felsőnyárádon egy 2 méter magas és $10 \mathrm{~m}$ széles tehergépjármű-forgalom miatt kialakított töltés aljában, az út melletti gyomos parlag szélén került elő. [7689.4].

*2396.2. Elymus hispidus (Opiz) Melderis subsp. barbulatus (Schur) Melderis - Ined.: Múcsony: Cseres-szőlő (BG 2021). Felhagyott szőlőben. [!7790.1].

2477. Stipa pennata L. - Lit.: Alsószuha: Virágos-oldal (Hegyes-hegy); Zádorfalva: Nagyszőlő-tető, Rakottyás-tető (MALATinszKY 2007). Ined.: Alsószuha: Lác-oldal, két kis folt (SzP 2021); Felsőkelecsény: Aradvány alja (BG 2021); Felsőnyárád: Mestergaz (SzP 1994), Őrhegy (BG 2020), Pincék (BG 2017); Kurityán: Koritó (BG 2021), Malom-mező (BG 2021), Susa-tető (SzP 2008), Szőlő-oldal (BG 2010); Ragály: Ortvány-kert (SzP 2008); Rudabánya: Agyagos-oldal (BG 2014); Szuhafő: Centu-hegy (SzP 2018); Zádorfalva: Arany-kúti-oldal (SzP 2008), Bakó (SzP 2008), Nagy-szőlő (SzP 1997), Nagy-szőlő alja (SzP 2008), Szellőtető (SzP 2016), Varjas-part (SzP 2019); Zubogy: Bodon alja (SzP 1995), Suba-oldal (BG 2016). Sztyepréteken nem ritka, felhagyott, másodlagos gyepekben terjed. [7588.4], [7589.3], [7688.2], [7689.1], [!7689.2], [7689.4].

*2479. Stipa pulcherrima K. Koch - Lit.: Galyaság: Szőlősardó (DúBRAKOvÁ-MicháLKova et al. 2008); Galyaság: Perkupa, Teresztenye (FARKAS 2010); Galyaság: Égerszög, Szőlősardó, Teresztenye, Varbóc; Rudabányai-hegység: Alsótelekes, Szendrő (VIRóK et al. 2016). Ined.: Izsófalva: Cseres-dűlő (SzP 2021), Gede-tető, kisebb foltok (SzP 2006); Kurityán: Susa-tető (BG 2013); Múcsony: Cseres-szőlő (BG 2017), Izsófalvi meddőhányó (BG 2017), Melegoldal, egy nagyobb és 6 kisebb folt (SzP 2006); Rudolftelep: Cseres-dűló (BG 2021), Gedeoldal, több száz m²-en (SzP 2021). A déli rész sztyeprétjein. [!7689.4], [!7690.3], [!7790.1].

2482. Danthonia alpina Vest - Herb.: Trizs (Jávorka és Zólyomi 1949, BP). Lit.: Flóratérképezési adat [1]: Jákfalva (Malatinszky Ákos és Penksza Károly 2003). Ined.: Izsófalva: Cseres-dűlő (BG 2021); Múcsony: Cseres-szőlő (BG 2021); Rudolftelep: Cseres-dűlő (BG 2021); Szuhafő: Virág-domb (SzP 2021); Zádorfalva: Bütykös alja (SzP 2021), Varjas-part (SzP 2021). Félszáraz irtásréteken. [!7588.4], [!7688.2], [!7790.1].

*2501. Leersia oryzoides (L.) Sw. - Herb.: Sajó-völgy: Múcsony (Virók 2003, DE). Lit.: Sajóvölgy: Sajókaza (MALATinszKY \& PEnKSZA 2002); Bódva-völgy: Szendrő (PenKSZA \& MALATINSZKY 2010); Bódva-völgy: Bódvaszilas; Hidvégardó (VIRóK et al. 2016). Ined.: Felsőnyárád: Kelecsényi-úton-felüli-dűlő (BG 2021). Árokban. [!7689.4].

2503. Panicum dichotomiflorum Michx. - Herb.: Felsőnyárád: Kurityáni-dűlő (Virók 2018, DE). Lit.: Felsőnyárád: Kurityáni-dűlő (MoLnÁR \& VIRÓK 2018); Kelemér (MolNÁR et al. 2020). Ined.: Felsőnyárád: Aradvány (BG 2021), Gyökér-kúti-dűlő (BG 2021), Jákfalvi-dúlő (BG 2021), Kelecsényi-úton-felüli-dűlő (BG 2021); Zubogy: Dövény-szögi-dűlő (BG 2021). Parlagon, kukoricás szélén néhány töves állományokban fordul elő. [!7689.1], [7689.4].

2505. Panicum miliaceum L. - Herb.: Felsőkelecsény: Kelecsényi-úton-aluli-dűlő (Virók 2001, DE). Lit.: Rudabányai-hegység: Szendrő (VIRóK et al. 2004). Ined.: Felsőkelecsény: Aradvány (BG 2021), Borsó-szer (BG 2021), Bozsdár (BG 2021), Felső-rét (BG 2021); Felsőnyárád: Gyökér-kúti-dűlő (BG 2021), Kelecsényi-úton-felüli-dúlő (BG 2021); Izsófalva: Cseres dűlő (BG 2021); Zubogy: Borsó-szer (BG 2021), Dövény-szögi-dűlő (BG 2021). Kukoricások és napraforgótábla szélén. Az izsófalvai példányok vörösessárga magvúak, a töb- 
bi világosabbtól sötét szürkésbarnáig terjedő színű, habitusukban nem voltak egyértelműen elkülöníthetők a P. miliaceum-tól. [!7689.1], [!7689.2], [!7689.4], [!7790.1].

2521. Chrysopogon gryllus (L.) Trin. - Lit.: Flóratérképezési adat [1]: Gömörszőlős (G. Farkas Tünde 2003). Ined.: Alsószuha: Feneketlen (SzP 2009); Kurityán: Koritó (BG 2020); Múcsony: Cseres-szőlő (BG 2021), Meleg-oldal (SzP 2008); Rudolftelep: Cseres-dűlő (SzP 2007); Sajókaza: Szár-hegy (BG 2020); Szuhafő: Centu-hegy (SzP 2021); Zádorfalva: Bütykös alja (SzP 2009), Latrány-völgy (SzP 2009), Ragyás-szőlő (SzP 2010). Száraz gyepekben, helyenként állományalkotó. [!7588.4], [7688.2], [!7689.1], [!7689.4], [!7789.2], [7790.1].

**** Eriochloa villosa (Thunb.) Kunth - Lit.: Sajó-völgy: Sajókeresztúr-Edelény (VIRóK et al. 2020). Ined.: Felsőnyárád: Szuha alja (BG 2021). Kukoricás szegélyében. [!7689.4].

*2541. Typha laxmannii Lepech. - Herb.: Rudabányai-hegység: Rudabánya (Virók 2004, DE). Lit.: Rudabányai-hegység: Rudabánya (VIRóK et al. 2004). Ined.: Izsófalva: Alsó-rétibányatavak (SzP 2005); Kurityán: Hencel-szög (SzP 2006). Tavak szélén, mocsarakban. [!7689.4], [!7789.2].

2613. Carex buekii Wimm. - Lit.: Alsószuha: Gyámol-völgy; Dövény és Alsószuha között a Szuha mellett; Imola: Fekete-völgy; Kelemér és Zádorfalva között a Gyámol-völgy kezdetén; Ragálytól délkeletre a Csörgős-patak mellett; Serényfalva és Kelemér közötti terület; Szuhafö: Szuha-völgy; Trizs feletti égeresben; Zubogy: Zúgó-völgy (Penksza \& Malatinszky 2001, MaLatinsZKY 2004); Alsószuha: Felső-rét, Rónya-puszta; Dövény: Alsó-rét; Jákfalva mellett; Szuhafő: Korlát-patak völgye; Zádorfalva: Bors-völgy, Iván-tető, Mocsolyás-völgy, Szuha-völgy (MALATinsZKY 2007); Kurityán: Csörgős-patak (Szuha) mellett (TAKÁCS et al. 2016). Ined.: Alsószuha: Alsó-rét (SzP 2012), Bakócz (SzP 2012), Feneketlen (SzP 2012), Kánya-völgy (SzP 2012); Dövény: Felső-rét (SzP 2012); Jákfalva: Alsó-rét (SzP 2012), Falurét (SzP 2012); Szuhafő: Pálykás (SzP 2001), Pető-háza (SzP 2010); Zádorfalva: Varjasvölgy (SzP 2010). Magassásosokban, mocsarakban, a területen gyakori. [7588.4], [7688.2], [7689.1], [7689.3].

2657. Cypripedium calceolus L. - Lit.: Gömörszőlős (MoLNÁR et al. 2016). Ined.: Zádorfalva: Ragyás-szőlő, 5 tő (SzP 2012). Sztyepréten, a megtalálás utáni években nem került elő. [7688.2].

2659. Epipactis microphylla (Ehrh.) Sw. - Herb.: Imola (Vojtkó 1999, BP). Ined.: Putnok: Kis-kő (BG 2019); Ragály: Kavacsos-part (BG 2015). Cseres-tölgyesben. [7589.3], [!7688.4].

2673. Epipactis helleborine (L.) Crantz - Lit.: Zádorfalva: Keskenyfark (FARKAS 2010). Ined.: Felsőnyárád: Kővágó (BG 2017); Szuhafő: Pető-házi-szőlő, 14 tő (SzP 2010). A Putnokidombságban ritka, gyertyános-tölgyesekben találtuk. [7688.2], [!7689.4].

2674. Epipactis purpurata Sm. - Lit.: Flóratérképezési adat [1]: Gömörszőlős (G. Farkas Tünde 2003). Ined.: Trizs: Bagoly-vágás (BG 2015), Rozsnyói-úti-bérc (BG 2015). Gyertyános-tölgyesekben szálanként fordul elő. [!7588.4].

2675. Cephalanthera rubra (L.) Rich. - Lit.: Imola: Kavacsos-part (BuDAY 1979). Ined.: Dubicsány: Galgóci-oldal (BG 2017); Putnok: Kis-kő (BG 2019); Sajógalgóc: Nagy-pallag (BG 2017). Nyirkos, árnyas erdőkben, cseres-tölgyesben, ritka. [7688.4], [7789.1].

2676. Cephalanthera damasonium (Mill.) Druce - Lit.: Imola: Kavacsos-part (BuDAY 1979); Gömörszőlős; Putnok; Zádorfalva: Égés-tető (PEnKSZA \& MALATINSZKY 2001); Jákfalva: Kaszálós-bérc; Sajókaza; Zádorfalva: Iván-tető (MALATinsZKY 2007). Ined.: Alsószuha: Feneketlen (SzP 2015), Jegenye-völgy (SzP 1999), Kánya-fő (SzP 2015), Vad-répás, telepített fenyvesben több ezer tő (SzP 2012); Dövény: Nyíres (SzP 2015); Felsőkelecsény: Aradványerdő (BG 2014), Kelecsényi-Nagy-hegy (SzP 1999); Felsőnyárád: Kis-erdő (BG 2014); Kurityán: Ormos-hegy (SzP 1993), Szőlő-oldal (BG 2014); Ragály: Kavacsos-part (BG 2015); Sajógalgóc: Nagy-pallag (BG 2017); Szuhafő: Pető-háza (SzP 2010); Zádorfalva: Bakó (SzP 2016), Berek eleje (SzP 2019), Bütykös-oldal (SzP 2017), Cseres alja (SzP 2017), Kis-völgy (SzP 2016), Nagy-völgy (SzP 2016), Ragyás-szőlő (SzP 2017), Varjas-part (SzP 2014). A faj 
a Putnoki-dombságban nem ritka, gyertyános-tölgyesekben, telepített fenyvesekben, nyárfasorban találtuk. [7588.4], [7589.3], [7688.2], [!7689.1], [7689.2], [7689.3], [7689.4], [7789.1].

2677. Cephalanthera longifolia (L.) Fritsch - Lit.: Alsószuha: Kocka-lápa-bérc; Dövény: Határ-völgy, Pencs-tető; Szuhafő: Gyertyános (MALATinszKY 2007); Kelemér (FARKAS 2010). Ined.: Dövény: Nyíres (SzP 2014), Varcsó (SzP 2008); Putnok: Páska (BG 2017); Ragály: Ortvány-kert (SzP 1996); Szuhafő: Pető-háza (SzP 2021), Pető-házi-szőlő (SzP 2006); Trizs: Diós-oldal (SzP 2013); Zádorfalva: Nagy-szőlő-tető (SzP 2014), Nagy-völgy (SzP 2008). Gyertyános-tölgyesekben, jobbára csak szálanként fordul elő. [7588.4], [7589.3], [7688.2], [7688.4], [7689.3].

2680. Neottia nidus-avis (L.). Rich. - Lit.: Gömörszőlős; Putnok; Szuhafő: Szuha-völgy; Trizs (PEnKSZA \& MALATINSZKY 2001); Alsószuha: Bakóc-völgy, Feneketlen-tető, Hideg-kút-völgy, Jegenye-völgy; Dövény: Határ-völgy, Pencs-tető, Szil-pataki-völgy; Felsőkelecsény: Őrfatető, Rózsás-tető; Imola: Bakbán, Leléte-völgy; Jákfalva: Hegyes-tető; Szuhafő: Pető-háza (MALATINSZKY 2007); Kelemér (FARKAS 2010). Ined.: Alsószuha: Büdös-kút-oldal (SzP 2010), Határ-völgy (SzP 2009), Kakas-vári-oldal (SzP 2014), Kánya-fő (SzP 2011), Kocka-lápa-bérc (SzP 2012), Virág-oldal (SzP 2014); Dövény: Akácos (BG 2017), Kavacs-domb (BG 2016), Mál-völgy (BG 2016), Varcsó (SzP 2006); Felsőkelecsény: Bozsdár-erdő (BG 2010); Felsőnyárád: Kis-erdő (BG 2014); Imola: Törés-oldal (BG 2016); Jákfalva: Szőlő-oldal (BG 2016); Kurityán: Ormos-hegy (SzP 1993); Ragály: Kavacsos-part (SzP 2012); Szuhafő: Gerenda (SzP 2016), Kerékkötő (SzP 2014), Pető-háza (SzP 2004), Pető-házi-szőlő (SzP 2010); Zádorfalva: Bütykös-oldal (SzP 2011), Cseres alja (SzP 2016), Iván-tető (SzP 2011), Nagyszőlő-tető (SzP 2011), Nagy-völgy (SzP 2008), Ragyás-szőlő (SzP 2021), Varjas-part (SzP 2010); Zubogy: Vadászházi-erdő (BG 2016). A faj a Putnoki-dombságban nem ritka, üde lomberdőkből került elő. [7588.4], [7589.3], [7688.2], [7689.1], [7689.2], [7689.3], [7689.4].

2686. Platanthera bifolia (L.) Rchb. - Lit.: Rudabánya (Soó et al. 1943); Gömörszőlős; Putnok; Szuhafő: Szuha-völgy; Trizs mellett (PENKSZA \& MALATinszKY 2001); Alsószuha: Bakócvölgy, Jegenye-völgy; Dövény: Tukó-hegy, Varcsó-völgy; Felsőkelecsény: Őrfa-tető, Rózsástető; Imola: Avas-oldal, Bakbán, Leléte-völgy; Jákfalva: Borcsog-föld; Sajógalgóc; Zádorfalva: Iván-tető, Kis-erdő-tető, Nagy-Szőlő-tető, Rakottyás-tető (MALATINSZKY 2007); Kelemér (FARKAS 2010). Ined.: Alsószuha: Bakóc-völgy (SzP 1993), Bakócz (SzP 2018), Feneketlen (SzP 2018), Határ-völgy (BG 2016), Hegyes-hegy (SzP 1996), Jegenye-völgy (SzP 2006), Kavacs-oldal (SzP 2017), Kánya-fő (SzP 2017), Kocka-lápa-bérc (SzP 2021), Ritka-dúlő, 2 tő (SzP 2006), Ritka-oldal, 1500 tő (SzP 2010), Virág-oldal (SzP 2014); Dövény: Mál-völgy (BG 2016), Pencs-tető, 8 tő (SzP 2009), Proletár-földek, 60 tő (SzP 2008); Felsőkelecsény: Galagonyás, 20 tő (BG 2010); Felsőnyárád: Mestergaz (BG 2014), Nagy-erdő, 30 tő (BG 2010), Ốr-hegy, 1 tő (BG 2010); Izsófalva: Cseres-dúlő (BG 2021), Kavicsos (BG 2017), Mogyoróska, 38 tő (SzP 2017); Jákfalva: Gyomor-oldal, 3 tő (SzP 2011), Jákvarcsó (SzP 2009), Németh-tag, 20 tő (BG 2010), Nyíres (SzP 1995); Kurityán: Kurityán-tető (BG 2012), Susa-tető (BG 2015), Szőlő-oldal (SzP 1994); Ragály: Batyik-völgy (SzP 1996), Csornok, 1 tő (SzP 2011), Ortvány-kert (SzP 1995); Rudabánya: Fekete-parlag (BG 2017); Rudolftelep: Cseresdúlő (BG 2013), Felső-rét, 1 tő (SzP 2008); Sajókaza: Ráró-szőlő (BG 2014); Szuhafő: Centuhegy, 15 tő (SzP 2009), Cinege-bérc, 4 tő (SzP 2010), Kerékkötő (SzP 2014), Kis kútnál (SzP 2017), Pálykás (SzP 2013), Pető-háza, 1000 tő (SzP 2006), Pető-házi-szőlő (SzP 2021), Pincék alja, 20 tő (SzP 1999), Virág-domb (SzP 1996), Zsilip-tető, 64 tő (SzP 2016); Trizs: Latrány útja (BG 2014), Parcellás, 5 tő (SzP 2009), Vermek-oldal (BG 2015); Zádorfalva: Latrány (SzP 2010), Pót-haraszt (SzP 2017), Ragyás-szőlő, 32 tő (SzP 2010), Rakottyás-tető (SzP 1996); Zubogy: Csiga-dúlő (BG 2016), Suba-oldal (BG 2020). A faj a Putnokidombságban nem ritka, bár nagyobb állományai jelentős csökkenést mutatnak. Mészkerülő 
gyepekben, ritkábban üde erdőkben találtuk. [7588.4], [7589.3], [7688.2], [7689.1], [7689.2], [7689.3], [7689.4], [7690.3], [!7789.2].

2688. Gymnadenia conopsea (L.) R. Br. - Lit.: Zádorfalva: Ragyás-szőlő (MALATINSZKY 2007). Ined.: Alsószuha: Ritka-oldal, 1 tő (SzP 2009); Szuhafő: Pálykás, 2 tő (SzP 2014), Pető-háziszőlő, 2016-ban 288 tő (SzP 2006), Pincék alja, 1 tő (SzP 2010); Zádorfalva: Nagy-szőlő, 1 tő (SzP 2011), Nagy-szőlő alja, 7 tő (SzP 1999), Rakottyás-tető, 2016-ban 221 tő (SzP 1996), Varjas-part, 2 tő (SzP 2005). Szálkaperjés gyepekben, erdőszegélyen került elő, állománya visszaszorulóban van. [7588.4], [7688.2], [!7689.1].

2693.2. Dactylorhiza incarnata (L.) Soó subsp. incarnata - Lit.: Gömörszőlős (PENKSZA \& MALATINSZKY 2001); Dövény: Alsó-rét, Felső-rét; Zádorfalva: Mocsolyás-völgy (MALATINSZKY 2004); Dövény: Alsó-rét, Felső-rét; Zádorfalva: Bors-völgy (MALATINSZKY 2007). Ined.: Dövény: Alsó-rét, 2020-ban 897 tő (SzP 1999), Felső-rét, 2020-ban 99 tő (SzP 2000), Kötélföld, 54 tő (SzP 2014); Felsőnyárád: Kelecsényi-úton-aluli-dűlő, 2008-ban 120 tő (SzP 2005); Jákfalva: Alsó-rét, 2020-ban 863 tő (SzP 1999), Falu-rét, 1 tő (SzP 2018). A faj a Putnoki-dombságban ritka, nedves réteken állománya hullámzó, de összességében csökkenő tendenciát mutat. [7689.1], [7689.3], [7689.4].

*2693.3. Dactylorhiza incarnata (L.) Soó subsp. serotina (Hausskn.) D.M. Moore et Soó Ined.: Dövény: Alsó-rét (SzP 2014). Nedves réten, az előző alfajnál ritkább. [!7689.3].

2694. Dactylorhiza majalis (Rchb.) P.F. Hunt et Summerh. - Lit.: Dövény: Alsó-rét (MALATINSZKY 2004, MALATINSZKY 2007). Ined.: Dövény: Alsó-rét, 2020-ban 186 tő (SzP 2000). Nedves réten, korábban a rét két további pontján is élt, de mára csak egy alig szobányi folton található meg. [7689.3].

*2693 × 2694. Dactylorhiza ×aschersoniana (Hausskn.) Borsos et Soó (Dactylorhiza incarnata (L.) Soó × majalis (Rchb.) P.F. Hunt et Summerh.) - Ined.: Dövény: Alsó-rét (SzP 2020). A szülőfajok között ritka. [!7689.3].

2700. Orchis morio L. - Lit:: Alsószuha: Virág-oldal; Alsószuha és Dövényi közötti Bakócvölgy; Putnok: Hegyes-tető; Szuhafő: Virág-domb; Trizs: Veres-sár; Ragály: Nyolcrendestanya feletti juhlegelőn (PEnKSZA \& MALATINSZKY 2001); Alsószuha: Virág-oldal; Alsószuha és Dövényi közötti Bakóc-völgy; Dövény és Jákfalva között a Varcsó-völgy környékének legelőin; Putnok: Hegyes-tető; Szuhafő: Virág-domb; Trizs: Veres-sár; Ragály: Nyolcrendestanya feletti juhlegelőn (MALATINSZKY 2004); Alsószuha: Virágos-oldal (Hegyes-hegy); Dövény: Varcsó-völgy; Imola: Fekete-völgy; Szuhafő: Pincék alja, Tubóka, Virág-domb; Zádorfalva: Rókalyuk (MALATINSZKY 2007); Imola: Temető (MoLNÁR V. \& LÖKI 2018); Kurityán és Sajókaza között (MoLnÁR et al. 2019). Ined.: Alsószuha: Bakóc-oldal, 1 tő (SzP 2011), Feneketlen, 56 tő (SzP 2015), Hegyes-hegy, 39 tő (SzP 2018), Jegenye-völgy, 50 tő (SzP 2001), Ritka-oldal, 2000 tő (SzP 2010); Felsőkelecsény: Aradvány, 2 tő (BG 2010), Aradvány alja, 1 tő (BG 2021), Bozsdár, 1 tő (BG 2010), Felső-rét, 9 tő (BG 2021), Galagonyás, 100 tő (BG 2010), Nagy-hegyi-szőlő, 20 tő (BG 2010); Felsőnyárád: Egyház megi dűlő, 30 tő (BG 2010), Kazai-dűlő (BG 2018), Kelecsényi-úton-aluli-dűlő, 23 tő (BG 2021), Kelecsényi-úton-felülidűlő (BG 2021), Kővágói-rét (SzP 1998), Mestergaz (SzP 1994), Nagy-erdő, 2000 tő (BG 2010), Őr-hegy, 2021-ben 1000 tő (BG 2005), Válós-út alja (SzP 1994); Imola: Ivó-kút, 700 tő (SzP 2021); Izsófalva: Cseres-dűlő, 1000 tő (SzP 1991), Gede-tető (SzP 2008), Hármashatár (BG 2016), Kavicsos (SzP 2021), Meszes (SzP 1996), Mogyoróska (BG 2014); Jákfalva: Borcsog-föld, 30 tő (BG 2010), Falu-rét (SzP 2021), Gyomor-oldal (SzP 2020), Jákvarcsó, 80 tő (SzP 2006), Kazai-oldal, 30 tő (BG 2010), Németh-tag, 30 tő (BG 2010), Nyírjes, 70 tő (SzP 2001); Kurityán: Kazai-oldal (BG 2018), Koritó, 50 tő (SzP 2009), Kurityán-tető, 200 tő (BG 2010), Susa-tető, 260 tő (SzP 2001), Szőlő-oldal (SzP 1991); Múcsony: Cseres-szőlő (BG 2017), Lác-völgy (BG 2017), Templom felett (BG 2017); Ragály: Csornok (SzP 1996), Hosszak-dúlő (BG 2013); Rudabánya: Huta-tető (SzP 2014), Imonyó-oldal (SzP 1995); Rudolftelep: Cseres-dűlő (SzP 1991), Edelényi-legelő (BG 2016), Felső-rét, 500 tő (SzP 2008), 
Szekeres alja (SzP 2018), Vattai-oldal, 200 tő (SzP 2008); Sajógalgóc: Padi-földek (BG 2017); Sajókaza: Pap-szőlők (BG 2010); Szuhafő: Centu-hegy, 1500 tő (SzP 2008), Petőháza, 1 tő (SzP 1997), Pető-házi-szőlő (SzP 2014), Puha-völgy (SzP 2014), Virág-domb, 150 tő (SzP 1997); Szuhakálló: Meleg-oldal (FL 2021); Trizs: Csörgős-patak völgye (SzP 2011), Eresztvény-tető (SzP 2016), Forrás-völgy (SzP 2021), Parcellás (SzP 2021); Zádorfalva: Bakó, 1 tő (SzP 2008), Kis-erdő-tető (SzP 2011), Latrány, 500 tő (SzP 2008), Latrány-völgy, 20 tő (SzP 2008), Nagy-szőlő (SzP 2018); Zubogy: Suba-oldal (BG 2018). A faj a Putnokidombságban nem ritka, legelőkön, félszáraz gyepeken került elő, állománya évenként erősen ingadozó. [7588.4], [7589.3], [7688.2], [7689.1], [7689.2], [7689.3], [7689.4], [7690.3], [7789.1], [7789.2], [7790.1].

2702. Orchis tridentata Scop. - Lit.: Gömörszőlős; Sajókaza: Ráró-hegy, Szár-hegy (PENKSZA \& MALATINSZKY 2001, MalatinsZKY 2004); Szuhafő: Pincék alja, Tubóka, Virág-domb; Zádorfalva: Iván-tető, Nagy-Szőlő-tető, Ragyás-szőlő, Rakottyás-tető (MALATINSZKY 2007); Gömörszőlős (FARKAS 2010); Alsószuha: Virágos-oldal (Hegyes-hegy); Kurityán: Kurityán-tető; Sajókaza; Szuhafő: Puha-völgy (MALATINSZKY \& ÁDÁm 2012); Zádorfalva: Temető (MoLnÁR V. \& LÖKI 2018). Ined.: Alsószuha: Feneketlen (SzP 2016), Hegyes-hegy (SzP 1999), Kánya-fő (SzP 2010), Kis-kánya-fő, 4 tő (SzP 2014), Lác-oldal (SzP 2016), Lengyel-oldal, 37 tő (SzP 2014), Vad-répás, 2014-ben 344 tő (SzP 1999); Dövény: Alsó-rét, 1 tő (SzP 2021); Felsőnyárád: Mestergaz (BG 2014); Kelemér: Erdő-alatti-kaszáló (BG 2018); Kurityán: Susa-tető (BG 2010); Ragály: Gerenda-oldal (SzP 2010), Ortvány-kert, 2014-ben 24 tő (SzP 2008); Rudolftelep: Edelényi-legelő (BG 2016); Sajókaza: Pap-szőlők (BG 2010), Szeles-tag (BG 2010); Szuhafő: Centu-hegy (SzP 2009), Cinege-bérc (SzP 2010), Kis kútnál (SzP 2009), Pálykás, 2014-ben 1208 tő (SzP 2006), Pető-háza (SzP 2009), Pető-házi-szőlő, 2014-ben 353 tő (SzP 2008), Pincék alja, 2014-ben 307 tő (SzP 1997), Puha-völgy, 2 tő (SzP 2011), Temető (SzP 2017), Virág-domb (SzP 2004), Zsilip-tető, 5 tő (SzP 1996); Szuhakálló: Melegoldal (FL 2021); Trizs: Akasztó-bérc (SzP 2010), Comád (SzP 2011), Csörgős-patak völgye, 1 tő (SzP 2020), Forrás-völgy (SzP 2021), Páris-völgy (SzP 2008), Rozsnyói-oldal (SzP 2011), Vermek-oldal (SzP 2008); Zádorfalva: Almás, 4 tő (SzP 2014), Arany-kúti-oldal, 2014-ben 148 tő (SzP 2009), Bakó, 2014-ben 253 tő (SzP 2008), Berek eleje, 2014-ben 589 tő (SzP 1999), Bütykös alja, 2014-ben 121 tő (SzP 2008), Cseres alja (SzP 2016), Cseresvölgy (SzP 2009), Iván-tető, 2014-ben 236 tő (SzP 2007), Kis-völgy (SzP 2016), Latrány (SzP 2008), Latrány-völgy (SzP 2008), Nagy-kánya-fő, 2 tő (SzP 2009), Nagy-szőlő, 2014ben 763 tő (SzP 2006), Nagy-szőlő alja, 2014-ben 371 tő (SzP 2006), Potrec, 1 tő (SzP 2005), Ragyás-szőlő, 2014-ben 786 tő (SzP 2006), Rakottyás-tető, 2014-ben 569 tő (SzP 1995), Szellő-tető, 2014-ben 463 tő (SzP 2010), Temető, 21 tő (SzP 2014), Templom-oldal, 3 tő (SzP 2011), Varjas-part, 2014-ben 723 tő (SzP 1996); Zubogy: Suba-oldal (BG 2016). A faj a Putnoki-dombságban nem ritka, szálkaperjés gyepekben került elő, az utóbbi tíz-húsz évben állománya jelentősen nőtt, Zádorfalva környékén több jelentősebb előfordulása ismert. [7588.4], [7589.3], [7688.2], [!7688.4], [7689.1], [!7689.3], [7689.4], [!7690.3], [7789.2].

2703. Orchis ustulata L. - Herb.: Szuhafő: Pálykás (Nagy 2014, DE). Lit.: Zádorfalva: Ivántető, Rakottyás-tető (MALATINSZKY 2007); Szuhafő: Pálykás; Zádorfalva: Iván-tető, Rakotytyás-tető (VIRóK et al. 2010). Ined.: Alsószuha: Feneketlen, 5 tő (SzP 2018), Hegyes-hegy, 11 tő (SzP 2018), Lác-oldal, 3 tő (SzP 2018); Jákfalva: Nyírjes, 3 tő (SzP 2009); Kurityán: Susatető, 1 tő (BG 2010); Ragály: Ortvány-kert (BG 2015); Sajókaza: Kétes-tető (BG 2014), Kurityán-tető (BG 2010), Ráró-szőlő (BG 2014), Szeles-tag (BG 2010); Szuhafő: Pálykás, 3 állományban 50 tő, nem azonos a Virók et al. (2010)-nél említett előfordulással (SzP 2010), Pető-házi-szőlő, 3 tő (SzP 2010), Pincék alja, 20 tő (SzP 2010), Tubóka (SzP 2021); Zádorfalva: Arany-kúti-oldal, 350 tő (SzP 2010), Bakó, 26 tő (SzP 2017), Berek eleje, 6 tő (SzP 2010), Cseres-völgy, 20 tő (SzP 2010), Iván-tető, 15 tő (SzP 1996), Nagy-szőlő alja (SzP 
2006), Ragyás-szőlő, 12 tő (SzP 2010), Rakottyás-tető, 2014-ben 869 tő (SzP 1998), Varjaspart, 2014-ben a dúlő több pontján 220 tő (SzP 1996). Szálkaperjés gyepekben és felhagyott szőlőben. Az Orchis tridentata Scop. sok élőhelyén megjelent, mindenütt a subsp. aestivalis (Kümpel) Kümpel et A. C. Mrkvicka alfaj fordul elő. A 2010-es évek közepéig állománya növekedett, de azóta a száraz nyarak nem kedveztek a fajnak. [7588.4], [!7589.3], [7688.2], [!7689.1], [7689.3], [7689.4], [7789.2].

2704. Orchis purpurea Huds. - Herb.: Felsőnyárád: Mestergaz (Takács 2014, DE). Lit.: Gömörszőlős; Sajókaza: Ráró-hegy, Szár-hegy, Trizstől északkeletre (Penksza \& MALATinszkY 2001); Gömörszőlős; Sajókaza: Ráró-hegy, Szár-hegy; Serényfalva; Trizstől északkeletre (MalatinszkY 2004); Ragály: Gerenda-oldal, Ortvány-kert; Szuhafő: Pincék alja, templom mellett (Centu-hegy); Zádorfalva: Elő-hegy, Iván-tető, Kis-erdő-tető, Latrány, Nagy-Szőlőtető, Ragyás-szőlő, Rakottyás-tető (MALATINSZKY 2007); Gömörszőlős; Kelemér; Zádorfalva: Róka-lyuk (FARKAS 2010); Kurityán: Kurityán-tető (MALATINSZKY \& ÁDÁM 2012); Gömörszőlős: Temető; Ragály: Temető; Szuhafő: Temető; Zádorfalva: Temető (MoLnÁR V. \& LÖKI 2018). Ined.: Alsószuha: Feneketlen (SzP 2016), Gyámol-völgy (SzP 2009), Hegyes-hegy (SzP 2008), Kánya-fő (SzP 2011), Kis-kánya-fö, 2 tő (SzP 2009), Lengyel-oldal, 34 tő (SzP 2014), Megye-berek (SzP 2011), Szilas-oldal (SzP 2020), Vad-répás, 2014-ben 111 tő (SzP 1996); Felsőkelecsény: Aradvány, 1 tő (BG 2021), Aradvány alja, 3 tő (BG 2021), Bozsdár (BG 2021); Felsőnyárád: Kis-erdő (BG 2013), Mestergaz (SzP 1995), Őr-hegy, 1 tő (BG 2021), Válós-út alja (BG 2013); Izsófalva: Kavicsos, 20 tő (BG 2021), Koplaló (BG 2014), Temető, 1 tő (SzP 2019); Kurityán: Koritó (SzP 2001), Malom-mező (BG 2013), Susa-tető (BG 2010), Szőlő-oldal (SzP 1994), Temető alj, 1 tő (BG 2016); Ormosbánya: Máris-rét, 1 tő (SzP 2021); Putnok: Gyenesfalvi-oldal (BG 2018), Kedves (BG 2018), Pál-völgy (BG 2018), Szőlő-hegy (BG 2018); Ragály: Batyik-völgy (SzP 1996), Csornok, 4 tő (SzP 2021), Ortványkert, 2014-ben 150 tő (SzP 1995), Temető (SzP 1997); Rudabánya: Bodon, 1 tő (BG 2010); Sajókaza: Pap-szőlők (BG 2010), Szeles-tag (BG 2010); Szuhafő: Centu-hegy (SzP 2008), Cinege-bérc (SzP 2010), Pálykás, 2014-ben 281 tő (SzP 1997), Pető-háza (SzP 1996), Petőházi-szőlő, 2014-ben 39 tő (SzP 2008), Pincék alja, 2014-ben 195 tő (SzP 1997), Puhavölgy, 15 tő (SzP 2014), Temető (SzP 2017), Tubóka (SzP 2021), Virág-domb (SzP 1997), Zsilip-tető, 76 tő (SzP 2010); Szuhakálló: Meleg-oldal (FL 2021), Nyomás, 5 tő (SzP 2011); Trizs: Akasztó-bérc (SzP 2011), Comád (SzP 2011), Csörgős-patak völgye (SzP 2016), Eresztvény-tető (SzP 2009), Páris-völgy (SzP 2016), Rozsnyói-oldal (SzP 2009), Vermeklápa (SzP 2016); Zádorfalva: Almás, 72 tő (SzP 2014), Arany-kúti-oldal, 2014-ben 452 tő (SzP 2008), Bakó, 116 tő (SzP 2014), Berek eleje, 2014-ben 230 tő (SzP 2003), Bors-völgy (SzP 2009), Bütykös alja, 2014-ben 20 tő (SzP 2008), Bütykös-oldal (SzP 2016), Cseres alja (SzP 2010), Cseres-völgy (SzP 2006), Gyámol, 1 tő (SzP 2014), Iván-tető, 2014-ben 224 tő (SzP 1995), Kis-völgy (SzP 2018), Latrány-völgy (SzP 2008), Mocsolyás-völgy (SzP 2016), Nagy-kánya-fő, 2014-ben 68 tő (SzP 2009), Nagy-szőlő, 2014-ben 197 tő (SzP 1997), Nagyszőlő alja, 2014-ben 390 tő (SzP 1997), Nagy-völgy (SzP 2011), Potrec (SzP 2011), Ragyásszőlő, 2014-ben 608 tő (SzP 2003), Rakottyás-tető, 2014-ben 1786 tő (SzP 1995), Szellőtető, 2014-ben 411 tő (SzP 1995), Temető, 26 tő (SzP 2014), Templom-oldal, 2014-ben 104 tő (SzP 2009), Varjas-part, 2014-ben 182 tő (SzP 1995); Zubogy: Suba-oldal (BG 2016). A faj a Putnoki-dombságban nem ritka, szálkaperjés gyepekben, felhagyott szőlőkben, száraz tölgyesekben, erdőszéleken, cserjésekben találtuk. A legnagyobb állományai Zádorfalva környékén élnek. [7588.4], [7589.3], [7688.2], [7688.4], [7689.1], [7689.2], [7689.4], [7788.2], [7789.2].

2705. Orchis militaris L. - Lit.: Gömörszőlős: Szőlő-hegy (PENKSZA et al. 1999/2000, PENKSZA \& MALATINSZKY 2001); Szuhafő: Pincék alja (MALATINSZKY 2007); Gömörszőlős (FARKAS 2010); Kurityán: Kurityán-tető (MALATINSZKY \& ÁDÁM 2012, TAKÁCS et al. 2016). Ined.: Szuhafő: Pálykás, 2016-ban 191 tő (SzP 2001); Zádorfalva: Iván-tető, 22 tő (SzP 2014); Rakoty- 
tyás-tető, 5 tő (SzP 2011). A faj a Putnoki-dombságban ritka, szálkaperjés gyepekben fordul elő, legnagyobb állománya 2016 után jelentősen csökkent. [7688.2].

$* 2704 \times 2705$. Orchis $\times$ hybrida Boenn. ex Rchb. (Orchis militaris L. $\times$ purpurea Huds.) Ined.: Zádorfalva: Rakottyás-tető, 1 tő (SzP 2014). Szálkaperjés gyepen a szülőfajok közelében. [!7688.2].

2708. Orchis elegans Heuff. - Lit.: Dövény: Alsó-rét, Felső-rét (MALATinsZKY 2004); Dövény: Alsó-rét, Felső-rét; Jákfalva mellett (Falu-rét) (MALATinszkY 2007). Ined.: Alsószuha: Alsórét, 5 tő (SzP 1999), Bakócz, 120 tő (SzP 1999); Dövény: Alsó rét, 2020-ban 1661 tő (SzP 1997); Felső-rét, 2019-ben 432 tő (SzP 1996), Kötél-föld, 2021-ben 9 tő (SzP 2004); Felsőkelecsény: Felső-rét, 400 tő (SzP 2005); Felsőnyárád: Csörgős-patak (BG 2009), Kelecsényiúton-aluli-dűlő, 2014-ben 31 tő (BG 2009), Kelecsényi-úton-felüli-dúlő, 4 tő (SzP 1993); Jákfalva: Alsó-rét, 2020-ban 1046 tő (SzP 1999), Falu-rét, 2020-ban 56 tő (SzP 2005), Gyökér-kúti-rét, 8 tő (SzP 2005). A faj a Putnoki-dombságban ritka, élőhelyei sérülékenyek, de állománya középhegységi viszonylatban jelentős. Mocsár- és lápréteken került elő. [7689.1], [7689.2], [7689.3], [7689.4].

\section{Köszönetnyilvánítás}

Meg szeretnénk köszönni Virók Viktornak a cikk elkészítéséhez nyújtott sokrétű segítségét (a kézirat átnézését és tanácsait, egyes fajok határozását, valamint a területre vonatkozó herbáriumi adatok rendelkezésünkre bocsátását). Fügedi Lászlót publikálatlan adatainak rendelkezésünkre bocsátásáért, Hudák Katalint és Visnyovszky Tamást a Gentiana pneumonanthe megtalálásához, míg Bátori Sándornét, Szentgyörgyi Veronikát, Szentgyörgyi Zsófiát, Szentgyörgyi Lucát, Bátori Sándort és ifjabb Szentgyörgyi Pétert a közös terepbejárások alkalmával nyújtott közreműködésükért illeti köszönet. Valamint köszönet illeti a kézirat bírálóit, Malatinszky Ákost és Molnár Csabát, értékes tanácsaikért és észrevételeikért.

\section{Irodalom}

BÁNKÚTI K. (1994): Adatok magyarország flórájához. - Folia Historico-Naturalia Musei Matrensis 19: 4749.

BÁNKÚTI K. (2000): A Mátra Múzeum herbáriuma - A Gotthárd gyűitemény II. Dicotyledonopsida: Berberidaceae-Fabacaea. - Folia Historico-Naturalia Musei Matrensis 24: 77-93.

BÁnкúti K. \& VojtKó A. (1995): Adatok a Sonchus palustris L. elterjedéséhez. - Folia Historico-Naturalia Musei Matrensis 20: 49-50.

Bartha D., Király G., Schmidt D., Tiborcz V., Barina Z., Csiky J., Jakab G., Lesku B., Schmotzer A., Vidéki R., Vojткó A. \& ZólYomi Sz. (szerk.) (2015): Magyarország edényes növényfajainak elterjedési atlasza. Nyugat-magyarországi Egyetem Kiadó, Sopron, 329 pp.

Boros Á. (1922): Florisztikai jegyzetek (útinaplók). - Kézirat. Magyar Természettudományi Múzeum Növénytár, Budapest.

BuDAI J. (1912): Növénygyưjtési feljegyzések. - Kézirat. Aggteleki Nemzeti Park Igazgatóság, Jósvafő.

BUDAI J. (1914): Adatok Borsodmegye flórájához. - Magyar Botanikai Lapok 13(10-12): 312-326.

BUDAY G. (1979): Phytozönologische und ökologische Bearbeitung der Vegetation des Schottergebietes in der Umgebung von Aggtelek I. Allgemeine Charakterisierung und die klimazonale Waldassoziation des Gebietes (Quercetum petraea-cerris roboretosum). - Acta Biologica Debrecina 16: 87-107.

Csiky J., Kovács D., Deme J., Takács A., Óvári M., Molnár V. A., Malatinszky Á., Nagy J. \& Barina Z. (2017): Taxonomical and chorological notes 4 (38-58). - Studia Botanica Hungarica 48(1): 133-144.

Csorba P. (szerk.) (2018): Tájak. - In: KIRÁLY K. (főszerk.), Magyarország Nemzeti Atlasza 2. kötet. Természeti környezet. Magyar Tudományos Akadémia, Csillagászati és Földtudományi Kutatóközpont, Földrajztudományi Intézet, Budapest, pp. 112-129. 
DöVÉNYI Z. (szerk.) (2010): Magyarország kistájainak katasztere. - MTA Földrajztudományi Kutatóintézet, Budapest, 876 pp.

Dúbraková-MichálKová D., Janisová M., Kolbek J., Suvada R., ViróK V. \& Zaliberová M (2008): Dry grasslands in the Slovensky Kras Mts. (Slovakia) and the Aggteleki-karszt Mts. (Hungary) - a comparison of two classification approaches. - Hacquetia 7(2): 123-140

FARKAS T. (2010): Adatok Borsod-Abaúj-Zemplén megye flórájához I. - Kitaibelia 15(1-2): 167-179.

Haszonits Gy., Molnár Cs., Sonkoly J., Tóthmérész B., TöröK P., Tóth E., Gnotek P., NAGY J., KoRdA M., ÁdÁM Sz., Malatinszky Á., Riezing N., Jóna Z. \& Séllei D. (2021): Pótlások Magyarország edényes növényfajainak elterjedési atlaszához XIII. - Kitaibelia 26(1): 85-88.

HuLJÁK J. (1926): Florisztikai adatok a Gömörszepesi érchegység és az Eperjes-Tokaji Hegylánc területének ismeretéhez. - Magyar Botanikai Lapok 25: 266-269.

HulJÁK J. (1937): Az Erythronium dens canis és néhány érdekesebb florisztikai adat a Magyar Középhegységből. - Botanikai Közlemények 34(1-2): 45-48.

KIRÁLY G. (szerk.) (2009): Új magyar füvészkönyv. Magyarország hajtásos növényei. Határozókulcsok. Aggteleki Nemzeti Park Igazgatóság, Jósvafő, 616 pp.

KIRÁLY G. \& HoRVÁtH F. (2000): Magyarország flórájának térképezése: lehetőségek a térképezés hálórendszerének megválasztására. - Kitaibelia 5(2): 357-368.

KIRÁLY G. \& KirÁLY A. (2018): Adatok és kiegészítések a magyar flóra ismeretéhez III. - Botanikai Közlemények 105(1): 27-96.

MALATıNSZKY Á. (2004): Botanikai értékek és tájgazdálkodási formák kapcsolata a Putnoki-dombságban. - Tájökológiai Lapok 2(1): 65-76.

MALATINSZKY Â. (2007): A Putnoki-dombság florisztikai kutatásának újabb eredményei. - Kitaibelia 12(1): 124-132.

MALATINSZKY Á. (2008): Relationships between cultivation techniques, vegetation, pedology and erosion on extensively cultivated and abandoned agricultural areas in the Putnok Hills. - Acta Agronomica Hungarica 56(1): 75-82.

MALATINSZKY Á. \& ÁDÁM Sz. (2012): Néhány érdekes florisztikai adat a Borsodi-dombságból. - Kitaibelia 17(1): 116.

MalatinszKy Á. \& PenKSZA K. (2002): Adatok a Sajó-völgy edényes flórájához. - Botanikai Közlemények 89(1-2): 99-104.

Molnár Cs., Bauer N., Csathó A. I., Szigeti V. \& Schmidt D. (2020): Az Oenothera pycnocarpa Atk. \& Bartl. Magyarországon, és kiegészítések néhány idegenhonos faj hazai elterjedéséhez. - Botanikai Közlemények 107(2): 177-202.

Molnár Cs., Haszonits Gy., Malatinszky Á., Kovács G. K., Kovács G., Nagy T., Molnár V. A. \& TakÁcs A. (2017): Pótlások Magyország edényes növényfajainak elterjedési atlaszához III. - Kitaibelia 22(1): $122-146$.

Molnár Cs., Haszonits Gy., Malatinszky Á., Süveges K., Balogh L., NaGy T., Horváth S. \& Hudák K. (2018): Pótlások Magyarország edényes növényfajainak elterjedési atlaszához VI. - Kitaibelia 23(1): 87102.

Molnár Cs., Haszonits Gy., Pintér B., Korda M., Peregrym M., Nótári K., Malatinszky Á., Toldi M. \& BerÁnek Á. (2019): Pótlások Magyország edényes növényfajainak elterjedési atlaszához IX. - Kitaibelia 24(2): 253-256.

Molnár Cs., Lengyel A., Molnár V. A., NAgy T., CsÁBi M., SÜVEges K., Lengyel-Vaskor D., Tóth Gy. \& TaKács A. (2016): Pótlások Magyarország edényes növényfajainak elterjedési atlaszához II. - Kitaibelia 21(2): 227-252.

MolNÁR Cs. \& VIRÓK V. (2018): A karcsú köles (Panicum dichotomiflorum) Gyöngyösön és Felsőnyárádon, valamint a faj terjedése az Északi-középhegységben. - Kitaibelia 23(2): 264-266.

MoLNÁR V. A. \& LÖKI V. (2018): Végveszélyben: a fejás temetők botanikai és kultúrtörténeti értékei Magyarországon és Erdélyben. - Kitaibelia 23(1): 51-64.

Penksza K. \& MalatinszKy Á. (2001): Adatok a Putnoki-dombság edényes flórájához I. - Kitaibelia 6(1): $149-155$.

Penksza K. \& MALATinszky Á. (2010): Adatok a Bódva-völgy edényes flórájához. - Botanikai Közlemények 97(1-2): 151-158.

PENKSZA K. \& Somlyay L. (1999): Geum rivale L. felfedezése Magyarországon. - Kitaibelia 4(2): 273-275.

Penksza K., Somlyay L. \& Malatinszky Á. (1999/2000): Adatok a Putnoki-dombság flórájához (Geum rivale stb.). - Botanikai Közlemények 86-87(1-2): 244. 
SCHMotzer A. (2019): New localities of Eleusine indica (Poaceae) and Phytolacca esculenta (Phytolaccaceae) in Eastern Hungary. - Studia Botanica Hungarica 50(1): 121-134.

SomLYAY L. (2000): Adatok a Dunazug-hegység, a Tornai-karszt és környéke flórájához - Kitaibelia 5(1): $47-52$.

SOMLYAY L. \& LŐKÖS L. (1999): Florisztikai és taxonómiai kutatások a Tornense területén. - Kitaibelia 4(1): 17-23.

Soó R., Boros Á., Igmándy J., Máthé I. \& UJVÁRosy M. (1943): Előmunkálatok a Bükkhegység és környéke flórájához. - Botanikai Közlemények 40: 169-221.

SZENTGYöRGYI P. (1994): Adatok a Putnoki-dombság flórájához. - Calandrella 8(1-2): 54-61.

SZENTGYÖRGYI P. (1996a): A Putnoki-dombság északi és keleti részének fátlan termőhelyein élő orchideái. - Calandrella 10(1-2): 54-57.

SZENTGYÖRGYI P. (1996b): A macskahere (Phlomis tuberosa) újabb előfordulása a Putnoki-dombságon. Calandrella 10(1-2): 220.

SZENTGYÖRGYI P. (1996c): Teleki virág (Telekia speciosa) Zádorfalváról. - Calandrella 10(1-2): 221.

SZENTGYÖRGYI P. (1996d): Konkoly (Agrostemma githago) és keskenylevelü gyapjúsás (Eriophorum angustifolium) Gömörszőlős-Pozsokon. - Calandrella 10(1-2): 222.

SzMORAD F. (2000): Adatok az Aggteleki-karszt és a Galyaság flórájához II. - Kitaibelia 5(1): 53-59.

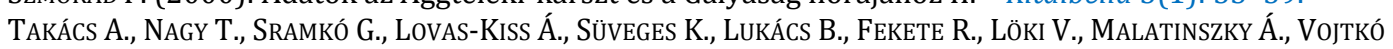
A., Koscsó J., Pfliegler W., Nótári K. \& MolnÁr V. (2016): Pótlások a Magyarország edényes növényfajainak elterjedési atlaszához I. - Kitaibelia 21(1): 101-115.

THAISZ L. (1910): Adatok Abaúj-Torna vármegye flórájához III. - Botanikai Közlemények 9(4-5): 222-230.

VARGÁNÉ SIPOS J. \& VARGA Z. (2014): A Teresztenyei-fennsík gyepeinek növénytársulástani viszonyai. ANP Füzetek 11: 63-84.

VIRÓK V. \& FARKAS R. (2007): Florisztikai adatok Borsod-Abaúj-Zemplén megye északi részéről II. Kitaibelia 12(1): 73-79.

ViróK V., FARKAS R., SzMorad F. \& BoldoghnÉ SzÚTS F. (2004): Florisztikai adatok Borsod-Abaúj-Zemplén megye északi részéről. - Kitaibelia 9(1): 143-150.

VIRÓK V., FARKAS R., FARKAS T., BoldoghnÉ SzÚTS F. \& VojtKó A. (2014): A Gömör-Tornai-karszt flórája Általános rész. - Aggteleki Nemzeti Park Igazgatóság, Jósvafő, 488 pp.

ViRóK V., FARKAS R., FARKAS T., SUVADA R. \& VojTKó A. (2016): A Gömör-Tornai-karszt flórája - Enumeráció. - Aggteleki Nemzeti Park Igazgatóság, Jósvafo, 200 pp. (digitális melléklettel).

Virók V., FARKaS R., GulYás G. \& SRAmkó G. (2010): Florisztikai adatok Borsod-Abaúj-Zemplén megye északi részéről III. - Kitaibelia 15(1-2): 73-84.

VIRÓK V., FARKAS T. \& KRAjNYÁK C. (2020): Az ázsiai gyapjúfü (Eriochloa villosa) elterjedésének vizsgálata Borsod-Abaúj-Zemplén megye északi részén. - Kitaibelia 25(1): 27-32.

VojTKó A. (2004): Polystichum braunii (Spenner) Fée a Tornense flórájának új tagja. - Kitaibelia 9(1): 221-223.

VojтKó A. (2008): Florisztikai adatok Észak-Magyarországról. - Kitaibelia 13(1): 55-61.

VojtKó A., SCHMOTZer A., PifKó D. \& FARKAS T. (1998): A Carex hartmanii Cajander újabb előfordulása és más kiegészítések a Tornense flórájának és vegetációjának ismeretéhez. - Kitaibelia 3(2): 235-241.

ZólYoмı B. (1928): Adatok a Bükk-hegység és környéke flórájához. - Magyar Botanikai Lapok 27(1-12): 63-64.

\section{Világháló-oldalak}

[1] BARTha D., BÁN M., Schmidt D. \& Tiborcz V. (2021): Magyarország edényes növényfajainak online adatbázisa (http://floraatlasz.uni-sopron.hu) - Soproni Egyetem, Erdőmérnöki Kar, Növénytani és Természetvédelmi Intézet. (hozzáférés: 2021.09.29.)

[2] Az Aggteleki Nemzeti Park Igazgatóság működési területének ESRI shapefile formátumú dűlőkatasztere. (http://anp.nemzetipark.gov.hu/terinformatika-adatbazis-letoltes) (hozzáférés: 2021.09.29.)

Beérkezett / received: 2021. 10.19. • Elfogadva / accepted: 2021. 12. 21.

\section{Elektronikus melléklet / Electronic appendix}

Enumeráció 2 
SZENTGYÖRGYI Péter \& BÁTORI Gábor (2022):

Adatok a Szuha-vízgyűjtő és környéke flórájához

Contributions to the flora of the Szuha watershed and adjacent territories (NE Hungary)

Kitaibelia 27(1): 27-67.

DOI: $10.17542 /$ kit.27.003

Elektronikus melléklet / Electronic appendix

\section{Enumeráció 2}

Ebben az enumerációban csak azokat az egyébként gyakori fajokra vonatkozó előfordulásokat tüntettük fel, melyek KEF alapmező szintjén nem szerepelnek a „Flóraatlaszban”, ezzel igyekszünk a terület flórájáról teljesebb képet rajzolni.

74. Larix decidua Mill. - Ined.: Dövény: Kavacs-domb (SzP 2010); Ragály: Nagy-erdő (SzP 2016); Zádorfalva: Cseres alja (SzP 2010). [!7588.4], [!7689.1], [!7689.3]. Nagyrészt telepítve fordul elő.

89. Juniperus communis L. - Ined.: Alsószuha: Ritka-oldal (SzP 2000); Jákfalva: Nyíres (SzP 2000). [!7689.1], [!7689.3].

131. Quercus pubescens Willd. - Ined.: Felsőnyárád: Mestergaz (BG 2019); Szuhafő: Pető-házi-szőlő (SzP 2012). [!7688.2], [!7689.4].

153. Thesium linophyllon L. - Ined.: Felsőnyárád: Mestergaz (BG 2021), Őr-hegy (BG 2021); Ragály: Ortvány-kert (SzP 2008). [!7589.3], [!7689.4].

155. Loranthus europaeus Jacq. - Ined.: Felsőkelecsény: Bozsdár-erdő (SzP 2008); Ragály: Cseres alja (SzP 2008), Ortvány-kert (SzP 2006); Zádorfalva: Latrány (SzP 2008). [!7588.4], [!7589.3], [!7689.2].

158. Aristolochia clematitis L. - Ined.: Zubogy: Zúgó-völgy (SzP 2008). [!7689.2].

159. Persicaria amphibia (L.) Delarbre - Ined.: Kurityán: Fekete-völgy (BG 2020), Vaskapu (BG 2021). [!7689.4].

161.2. Persicaria Iapathifolia (L.) Delarbre subsp. lapathifolia - Ined.: Alsószuha: Kánya-völgy (SzP 2002); Dövény: Belterület (SzP 2002); Ragály: Belterület (SzP 2004); Zádorfalva: Szuha-völgy (SzP 2002). [!7589.3], [!7688.2], [!7689.1], [!7689.3].

162. Persicaria maculosa Gray - Ined.: Dövény: Alsó-rét (SzP 2002), Felső-rét (SzP 2002); Kurityán: Fekete-völgy (SzP 2000). [!7689.1], [!7689.3], [!7689.4].

179. Fallopia convolvulus (L.) A. Löve - Ined.: Ragály: Barom-szer (SzP 2006). [!7589.3].

188. Rumex thyrsiflorus Fingerh. - Ined.: Felsőnyárád: Szuha (BG 2021), Szuha alja (BG 2021); Imola: Ivó-kút (SzP 2021); Izsófalva: Cseres-dűlő (BG 2021); Jákfalva: Köteles (BG 2021), Köteles alja (BG 2021), Szőlők alja (BG 2021); Kurityán: Belterület (BG 2021); Múcsony: Cseres-szőlő (BG 2021). [!7589.3], [!7689.3], [!7689.4], [!7790.1].

196. Rumex obtusifolius L. - Ined.: Jákfalva: Köteles alja (BG 2021). [!7689.3].

202. Rumex crispus L. - Ined.: Zádorfalva: Latrány-völgy (SzP 2008). [!7588.4].

221. Chenopodium polyspermum L. - Ined.: Kurityán: Kurityáni-bányató (SzP 2006). [!7689.4].

236. Atriplex patula L. - Ined.: Felsőnyárád: Fekete-völgyi bánya (SzP 2007); Ormosbánya: Gyilkos-tó (SzP 2006). [!7689.4].

276. Portulaca oleracea L. - Ined.: Felsőkelecsény: Belterület (SzP 2021); Felsőnyárád: Belterület (SzP 2006), Gyökér-kúti-dűlő (BG 2021); Imola: Belterület (SzP 2021); Izsófalva: Belterület (SzP 2006); Kurityán: Belső-szög (BG 2021); Ragály: Belterület (SzP 2021); Szuhafő: Belterület (SzP 2021); Zádorfalva: Berek eleje (SzP 2005). [!7588.4], [!7589.3], [!7688.2], [!7689.2], [!7689.4].

299. Holosteum umbellatum L. - Ined.: Felsőkelecsény: Aradvány (BG 2021). [!7689.2].

314. Myosoton aquaticum (L.) Moench - Ined.: Ragály: Belterület (SzP 2006). [!7589.3].

336. Lychnis viscaria L. - Ined.: Felsőnyárád: Mestergaz (SzP 2006), Németh-tag (SzP 2008); Izsófalva: Cseres-dűlő (SzP 2006), Gede-tető (SzP 2006); Kurityán: Kazai-oldal (SzP 2006); Rudolftelep: Cseresdűlő (BG 2021); Szuhafő: Pincék alja (SzP 2006); Trizs: Csörgős-patak völgye (SzP 2009), Parcellás (SzP 2009), Vermek-oldal (SzP 2008). [!7588.4], [!7689.4], [!7789.2], [!7790.1].

339. Silene otites (L.) Wibel - Ined.: Felsőnyárád: Mestergaz (BG 2019), Őr-hegy (BG 2021); Kurityán: Susa-tető (SzP 2006); Múcsony: Meleg-oldal (SzP 2006); Rudolftelep: Cseres-dűlő (BG 2021). [!7689.4], [!7790.1]. 
355. Cucubalus baccifer L. - Ined.: Alsószuha: Gyámol-völgy (SzP 2021), Kánya-völgy (SzP 2021); Jákfalva: Kender-földek (SzP 2012), Szőlők alja (BG 2021). [!7689.1], [!7689.3].

361. Saponaria officinalis L. - Ined.: Alsószuha: Kánya-völgy (SzP 2021), Szuha (SzP 2021). [!7689.1].

364. Petrorhagia prolifera (L.) P.W. Ball et Heywood - Ined.: Felsőnyárád: Őr-hegy (SzP 2006); Kurityán:

Fekete-völgy (BG 2020); Ormosbánya: Ormos-tábla (SzP 2021); Zádorfalva: Latrány (SzP 2021). [!7588.4], [!7689.4].

375. Dianthus armeria L. - Ined.: Izsófalva: Cseres-dűlő (SzP 2006); Zádorfalva: Iván-tető (SzP 2021), Ragyás-szőlő (SzP 2008), Varjas-part (SzP 2021). [!7688.2], [!7790.1].

394. Isopyrum thalictroides L. - Ined.: Rudabánya: Sár-völgy-erdő (BG 2018); Szuhafő: Pető-háza (SzP 2001); Trizs: Comád: (SzP 2006), Rozsnyói-oldal (SzP 2006). [!7588.4], [!7688.2], [!7689.2].

427. Adonis aestivalis L. - Ined.: Ragály: Gerenda-oldal (SzP 2006); Ortvány-kert (SzP 2006). [!7589.3].

480. Papaver dubium L. - Ined.: Alsószuha: Alsó-rét (SzP), Bakócz (SzP 2021), Külső-rónya (SzP 2021), Ritka-dúlő (SzP 2021); Dövény: Alsó-rét (SzP 2021), Felső-rét (SzP 2021), Gödör-köz-dűllő (SzP 2021), Kötél-föld (SzP 2021); Jákfalva: Alsó-rét (SzP 2021), Kender-földek (SzP 2021), Köteles (SzP 2021), Köteles alja (SzP 2021); Ragály: Isten harasztja (SzP 2011), Ortvány-kert (SzP 2005). [!7589.3], [!7689.1], [!7689.3].

485. Corydalis cava L. - Ined.: Trizs: Oltványos-dűlő (SzP 2006). [!7589.3].

492. Fumaria schleicheri Soy.-Will. - Ined.: Felsőnyárád: Fekete-völgy (SzP 2007); Ragály: Barom-szer (SzP 2006); Szuhafő: Pető-háza (SzP 2006); Zádorfalva: Szellő-tető (SzP 2010), Szuha-völgy (SzP 2006). [!7589.3], [!7688.2], [!7689.4].

496. Sisymbrium strictissimum L. - Ined.: Dövény: Alsó-rét (SzP 2011), Tófenék (SzP 2007); Jákfalva: Süveges alja (SzP 2006); Ragály: Csörgős-patak (SzP 2006). [!7589.3], [!7689.1], [!7689.3].

501. Descurainia sophia (L.) Webb - Ined.: Felsőnyárád: Kelecsényi-úton-aluli-dűlő (BG 2021); Kurityán: Belterület (BG 2021). [!7689.4].

503. Arabidopsis thaliana (L.) Heynh. - Ined.: Dövény: Alsó-rét (SzP 2021). [!7689.3].

556. Alyssum alyssoides L. - Ined.: Felsőnnyárád: Mestergaz (BG 2021), Őr-hegy (BG 2021). [!7689.4].

562. Rorippa austriaca (Crantz) Besser - Ined.: Izsófalva: Cseres-dúlő (SzP 2006); Rudolftelep: Cseresdűlő (BG 2021). [!7790.1].

567. Rorippa sylvestris (L.) Besser - Ined.: Izsófalva: Alsó-rét (SzP 2006); Rudolftelep: Cseres-dűlő (BG 2021). [!7789.2], [!7790.1].

602. Cardaria draba (L.) Desv. - Ined.: Alsószuha: Felső-rét (SzP 2021), Kánya-völgy (SzP 2021); Dövény: Alsó-rét (SzP 2021), Kötél-föld (SzP 2021); Ragály: Barom-szer (SzP 2021). [!7589.3], [!7689.1], [!7689.3].

616. Sinapis arvensis L. - Ined.: Felsőkelecsény: Aradvány alja (BG 2021). [!7689.2].

623. Raphanus raphanistrum L. - Ined.: Ragály: Ortvány-kert (SzP 2006); Trizs: Csörgős-lapos (SzP 2006); Parcellás (SzP 2009). [!7588.4], [!7589.3].

642. Sedum sexangulare L. - Ined.: Ormosbánya: Mogyoróska (BG 2016). [!7689.4].

643. Sedum acre L. - Ined.: Dövény: Pencs-oldal (SzP 2009); Imola: Belterület (SzP 2021); Jákfalva: Belterület (SzP 2005); Szuhafő: Belterület (SzP 2021); Zádorfalva: Belterület (SzP 2021); Zubogy: Belterület (SzP 2006). [!7588.4], [!7589.3], [!7688.2], [!7689.1], [!7689.3].

685. Rosa gallica L. - Ined.: Alsószuha: Hegyes-hegy (SzP 2015). [!7689.1].

711. Sanguisorba officinalis L. - Ined.: Alsószuha: Alsó-rét (SzP 1998); Dövény: Felső-rét (SzP 1998); Felsőnyárád: Szuha alja (BG 2013); Kurityán: Fekete-völgy (BG 2020), Henczel-szög (SzP 2012); Ragály: Csörgős-patak - falu alatti szakasz (BG 2020), Határnál (SzP 2006), Hosszak-dűlő (BG 2020); Zubogy: Doma alja (BG 2021), Meskó-rét (SzP 2006), Szuhucer (BG 2021). [!7689.1], [!7689.4].

712. Sanguisorba minor Scop. - Ined.: Alsószuha: Lác-oldal (SzP 2010), Vad-répás (SzP 2015); Felsőnyárád: Őr-hegy (BG 2021); Izsófalva: Kavicsos (SzP 2021); Kurityán: Koritó (BG 2015), Malommező (BG 2021), Susa-tető (BG 2021), Szőlő-oldal (BG 2021); Ragály: Gerenda-oldal (SzP 2010); Rudolftelep: Cseres-dúlő (BG 2021). [!7589.3], [!7689.1], [!7689.4], [!7790.1].

720. Potentilla alba L. - Ined.: Sajókaza: Pap-szőlők (BG 2010). [!7689.4].

724. Potentilla erecta (L.) Rausch - Ined.: Alsószuha: Jegenye-völgy (SzP 2008), Ritka-oldal (SzP 2009); Jákfalva: Nyírjes (SzP 2009). [!7689.1], [!7689.3].

835. Lembotropis nigricans (L.) Griseb. - Ined.: Alsószuha: Feneketlen (SzP 2009), Ritka-oldal (SzP 2009), Szarvas-oldal (SzP 2009); Szuhafő: Centu-hegy (SzP 2009), Pálykás (SzP 2009), Pető-háza (SzP 2009), Pető-házi-szőlő (SzP 2010), Pincék alja (SzP 2000); Trizs: Eresztvény-tető (SzP 2009); Zádorfalva: Berek eleje (SzP 2009), Cseres-völgy (SzP 2009), Iván-tető (SzP 2009), Nagy-szőlő (SzP 2009), Nagy-szőlő alja (SzP 2009), Potrec (SzP 2009), Ragyás-szőlő (SzP 2006), Rakottyás-tető (SzP 2009), Szellő-tető (SzP 2021), Varjas-part (SzP 2009). [!7588.4], [!7688.2], [!7689.1]. 
838. Chamaecytisus supinus (L.) Link - Ined.: Alsószuha: Büdös-kút-oldal (SzP 2009), Hegyes-hegy (SzP 2009), Jegenye-völgy (SzP 2006), Szarvas-oldal (SzP 2009), Virág-oldal (SzP 2021); Szuhafő: Pálykás (SzP 2021), Pető-házi-szőlő (SzP 2021); Zádorfalva: Ragyás-szőlő (SzP 2006), Varjas-part (SzP 2005). [!7688.2], [!7689.1].

846. Chamaecytisus triflorus (Lam.) Skalická - Ined.: Alsószuha: Jegenye-völgy (SzP 2006). [!7689.1].

870. Astragalus cicer L. - Ined.: Felsőnyárád: Jákfalvi-dúlő (BG 2021). [!7689.4].

879. Amorpha fruticosa L. - Ined.: Zádorfalva: Berek eleje (SzP 2021). [!7688.2].

891. Vicia pisiformis L. - Ined.: Rudolftelep: Mák-völgy (SzP 2008); Szuhafő: Pető-háza (SzP 2009), Petőházi-szőlő (SzP 2008). [!7688.2], [!7690.3].

896. Vicia villosa Roth. - Ined.: Dövény: Alsó-rét (SzP 2006); Felsőkelecsény: Száraz-rét (SzP 2006); Felsőnyárád: Egyház megi dűlő (SzP 2007); Jákfalva: Köteles (SzP 2009). [!7689.2], [!7689.3], [!7689.4].

901. Vicia pannonica Crantz - Ined.: Dövény: Kerek-föld (SzP 2021); Zubogy: Suba-oldal (BG 2021). A dövényi példány subsp. pannonica, a zubogyi példány átmeneti alak: a subsp. pannonica-tól eltérően a vitorla lemeze halvány rózsaszín sötét erezettel. [!7689.1], [!7689.3].

905. Vicia sepium L. - Ined.: Alsószuha: Kánya-völgy (SzP 2021); Dövény: Alsó-rét (SzP 2021), Belterület (SzP 2006); Felsőnyárád: Kelecsényi-úton-aluli-dűlő (SzP 2006), Kelecsényi-úton-felüli-dúlő (SzP 2006), Mestergaz (BG 2021), Szuha (BG 2021); Kurityán: Szuha (BG 2021); Sajókaza: Pap-szőlők (BG 2020). [!7689.1], [!7689.3], [!7689.4].

912. Lathyrus pratensis L. - Ined.: Múcsony: Cseres-szőlő (BG 2021). [!7790.1].

916. Lathyrus hirsutus L. - Ined.: Ragály: Barom-szer (SzP 2010), Csikó-rét (SzP 2010), Dobrosó-oldal (SzP 2007), Fagyalas (SzP 2010), Gerenda-oldal (SzP 2008); Szuhafó: Alsó-rét (SzP 2007), Virág-domb (SzP 2012). [!7588.4], [!7589.3].

929. Lathyrus vernus (L.) Bernh. - Ined.: Zádorfalva: Nagy-völgy (SzP 2008). [!7588.4].

934. Ononis spinosa L. - Ined.: Szuhafő: Pincék alja (SzP 2006). [!7588.4].

935. Ononis arvensis L. - Ined.: Ragály: Barom-szer (SzP 2009), Fagyalas (SzP 2010), Csornok (SzP 2010), Ravasz-rész (SzP 2010). [!7589.3].

972. Trifolium rubens L. - Ined.: Alsószuha: Kis-kánya-fő (SzP 2009); Ragály: Ortvány-kert (SzP 2009). [!7589.3], [!7689.1].

973. Trifolium alpestre L. - Ined.: Múcsony: Meleg-oldal (SzP 2007). [!7790.1].

1003. Oxalis stricta L. - Ined.: Alsószuha: Alsó-rét (SzP 2021), Jegenye-völgy (SzP 2013); Dövény: Alsórét (SzP 2021), Belterület (SzP 2012); Jákfalva: Köteles (SzP 2009), Süveges alja (SzP 2013). [!7689.1], [!7689.3].

1009. Geranium sanguineum L. - Ined.: Alsószuha: Feneketlen (SzP 2010), Hegyes-hegy (SzP 2006). [!7689.1].

1014. Geranium columbinum L. - Ined.: Alsószuha: Kakas-vári-oldal (SzP 2008), Ritka-dűlő (SzP 2008), Szilas-oldal (SzP 2010); Dövény: Pencs-oldal (SzP 2021); Felsőnyárád: Jákfalvi-dúlő (SzP 2006), Őr-hegy (BG 2021); Jákfalva: Süveges-oldal (BG 2021); Szuhafő: Pincék alja (SzP 2010). [!7588.4], [!7689.1], [!7689.3], [!7689.4].

1020. Geranium molle L. - Ined.: Felsőkelecsény: Belterület (BG 2021). [!7689.2].

1021. Geranium pusillum Burm. f. - Ined.: Izsófalva: Belterület (SzP 2010), Temető (SzP 2021). [!7689.4].

1023. Erodium cicutarium (L.) L' Hér. - Ined.: Izsófalva: Kállói-tag (SzP 2005), Szekeres (SzP 2021); Kurityán: Szőlő-oldal (SzP 2006); Múcsony: Cseres-szőlő (SzP 2008); Trizs: Pallagok (SzP 2021). [!7588.4], [!7689.4], [!7789.2], [!7790.1].

1044. Euphorbia helioscopia L. - Ined.: Felsőkelecsény: Felső-rét (BG 2021); Kurityán: Vaskapu (SzP 2006); Ragály: Ortvány-kert (SzP 2006). [!7589.3], [!7689.2], [!7689.4].

1057. Euphorbia amygdaloides L. - Ined.: Alsószuha: Bakóc-völgy (SzP 2008), Hideg-kút-völgy (SzP 2015), Virág-oldal (BG 2015); Dövény: Mál-völgy (BG 2015). [!7689.1], [!7689.3].

1061. Euphorbia esula L. - Ined.: Rudolftelep: Cseres-dúlő (BG 2021). [!7790.1].

1073. Ailanthus altissima (Mill.) Swingle - Ined.: Ragály: Ortvány-kert (SzP 2009). [!7589.3].

1117. Malva sylvestris L. - Ined.: Izsófalva: Kavicsosi-bányató (SzP 2006); Múcsony: Meleg-oldal (SzP 2006). Sajó-völgy: Múcsony: Belterület (SzP 2006), Bika-rét (SzP 2006); Szuhakálló: Belterület (SzP 2021). [!7789.2], [!7790.1].

1121. Lavatera thuringiaca L. - Ined.: Alsószuha: Alsó-rét (SzP 2006), Bakócz (SzP 2006), Felső-rét (SzP 2006), Feneketlen (SzP 2021), Kánya-völgy (SzP 2021), Ritka-dűlő (SzP 2006); Dövény: Felső-rét (SzP 2005), Tófenék (SzP 2006); Izsófalva: Kavicsosi-bányató (SzP 2006), Mák-patak völgye (SzP 2006); Jákfalva: Süveges alja (SzP 2006); Múcsony: Meleg-oldal (SzP 2006); Zubogy: Belterület (SzP 2021). Sajóvölgy: Múcsony: Bika-rét (SzP 2006); Szuhakálló: Belterület (SzP 2006). [!7689.1], [!7689.3], [!7789.2], [!7790.1]. 
1125. Althaea officinalis L. - Ined.: Ragály: Belterület (SzP 2005), Csörgős-patak (SzP 2006), Dobrosóoldal (SzP 2007); Trizs: Csörgős-lapos (SzP 2006). [!7589.3].

1142. Hypericum tetrapterum Fr. - Ined.: Dövény: Alsó-rét (SzP 2014). [!7689.3].

1150. Viola tricolor L. s. str. - Ined.: Múcsony: Cseres-szőlő (BG 2021). [!7790.1].

1158. Viola hirta L. - Ined.: Dövény: Pencs-oldal (SzP 2008). [!7689.1].

1164. Viola canina L. s. l. - Ined.: Alsószuha: Jegenye-völgy (SzP 2010); Szuhafő: Pető-háza (SzP 2011); Trizs: Parcellás (SzP 2021). [!7588.4], [!7688.2], [!7689.1].

1169. Helianthemum ovatum (Viv.) Dunal in DC. - Ined.: Alsószuha: Feneketlen (SzP 2007), Kánya-fó (SzP 2010). [!7689.1].

1189. Echinocystis lobata (Michx.) Torr. et A. Gray - Ined.: Ragály: Csörgős-patak (SzP 2006). [!7589.3].

1197. Lythrum hyssopifolia L. - Ined.: Zubogy: Kert alja (BG 2021), Tanya alja (BG 2021). [!7689.1].

1217. Chamaenerion angustifolium (L.) Scop. - Ined.: Alsószuha: Ritka-oldal (SzP 2009); Dövény: Alsórét (SzP 2021), Pencs-oldal (SzP 2009); Múcsony: Cseres-szőlő (BG 2021); Ragály: Csornok (SzP 2007). [!7589.3], [!7689.1], [!7689.3], [!7790.1].

1228. Epilobium tetragonum L. s. l. - Ined.: Ragály: Batyik-völgy (SzP 2010), Csornok (SzP 2010), Ravasz-rész (SzP 2010). [!7589.3].

1241. Sanicula europaea L. - Ined.: Alsószuha: Határ-völgy (SzP 2021), Kocka-lápa-bérc (SzP 2009); Felsőkelecsény: Szakáll-hegy (BG 2021). [!7689.1], [!7689.2].

1282. Conium maculatum L. - Ined.: Felsőkelecsény: Száraz-rét (BG 2020). [!7689.2].

1309. Peucedanum carvifolia Vill. - Ined.: Felsőkelecsény: Aradvány (BG 2020), Aradvány alja (BG 2021), Száraz-rét (BG 2020); Zubogy: Borsó-szer (BG 2020), Csepegős (BG 2021), Doma alja (BG 2021). [!7689.1], [!7689.2].

1361. Anagallis arvensis L. - Ined.: Felsőnyárád: Aradvány (BG 2021), Egyház megi dűlő (SzP 2007), Gyökér-kúti-dúlő (BG 2021), Jákfalvi-dűlő (BG 2021), Kelecsényi-úton-aluli-dűlő (BG 2021), Kelecsényiúton-felüli-dűlő (BG 2021), Mestergaz (SzP 2008), Németh-tag (SzP 2008), Szuha alja (SzP 2007); Izsófalva: Belterület (SzP 2006); Kurityán: Kazai-oldal (SzP 2006), Malom-mező (BG 2021), Vaskapu (SzP 2006). [!7689.4].

1383. Centaurium erythraea Raf. - Ined.: Ragály: Csornok (SzP 2021), Dobrosó-oldal (SzP 2007). [!7589.3].

1393. Vinca minor L. - Ined.: Imola: Törés-oldal (BG 2017). [!7589.3].

1407. Cuscuta epithymum (L.) Nath. - Ined.: Alsószuha: Alsó-rét (SzP 2009); Dövény: Belterület (SzP 2009); Felsőnyárád: Kelecsényi-úton-felüli-dűlő (SzP 2012); Izsófalva: Alsó-rét (SzP 2012), Cseres-dűlő (SzP 2012); Kurityán: Hencel-szög (SzP 2012). [!7689.1], [!7689.3], [!7689.4], [!7789.2], [!7790.1].

1412. Lithospermum officinale L. - Ined.: Felsőnyárád: Mestergaz (BG 2015); Kurityán: Kazai-oldal (BG 2016), Susa-tető (BG 2010), Szőlő-oldal (BG 2021). [!7689.4].

1413. Buglossoides purpurocaerulea (L.) I.M. Johnston - Ined.: Ormosbánya: Tagosok (SzP 2021); Zádorfalva: Ragyás-szőlő (SzP 2013). [!7688.2], [!7689.4].

1414. Buglossoides arvensis (L.) I.M. Johnston - Ined.: Kurityán: Fekete-völgy (BG 2021), Malom-mező (SzP 2021). [!7689.4].

1418. Cerinthe minor L. - Ined.: Felsőnyárád: Fekete-völgy (SzP 2007), Mestergaz (SzP 2006); Kurityán: Fekete-völgy (SzP 2006), Kazai-oldal (SzP 2006), Susa-tető (SzP 2006), Szőlő-oldal (SzP 2006). [!7689.4]. 1428. Nonea pulla (L.) DC. - Ined.: Múcsony: Meleg-oldal (SzP 2006). [!7790.1].

1437. Anchusa officinalis L. - Ined.: Felsőnyárád: Belterület (SzP 2006), Kelecsényi-úton-aluli-dúlő (SzP 2006), Kelecsényi-úton-felüli-dűlő (SzP 2006), Mestergaz (SzP 2005); Múcsony: Meleg-oldal (SzP 2006). [!7689.4], [!7790.1].

1449. Myosotis sparsiflora J. G. Mikan - Ined.: Ormosbánya: Tagosok (SzP 2021). [!7689.4].

1480. Scutellaria galericulata L. - Ined.: Alsószuha: Kánya-völgy (SzP 2021); Felsőnyárád: Kelecsényiúton-aluli-dűlő (BG 2020); Izsófalva: Kavicsosi-bányató (SzP 2006), Szuha (SzP 2006); Jákfalva: Gyökérkúti-rét (BG 2020); Kurityán: Fekete-völgy (BG 2020), Koritó (SzP 2006), Szuha (BG 2020). [!7689.1], [!7689.4].

1492. Galeopsis pubescens Besser - Ined.: Alsószuha: Határ-völgy (SzP 2009); Dövény: Pencs-tető (SzP 2009), Varcsó (SzP 2008). [!7689.1], [!7689.3].

1493. Galeopsis speciosa Mill. - Ined.: Ragály: Csörgős-patak (SzP 2006); Szuhafő: Pető-házi-szőlő (SzP 2009); Zádorfalva: Szuha-völgy (SzP 2021); Zubogy: Borsó-szer (BG 2021), Csörgős-patak - falu alatti szakasz (BG 2021). [!7589.3], [!7688.2], [!7689.2].

1499. Lamium amplexicaule L. - Ined.: Felsőnyárád: Őr-hegy (BG 2021); Kurityán: Fekete-völgy (BG 2021). [!7689.4].

1504. Leonurus cardiaca L. - Ined.: Felsőnyárád: Kelecsényi-úton-felüli-dűlő (BG 2020); Izsófalva: Mogyoróska (SzP 2006). [!7689.4]. 
1508. Stachys annua L. - Ined.: Felsőnyárád: Jákfalvi-dűlő (BG 2021), Kővágó alja (BG 2021), Őr-hegy (BG 2021); Kurityán: Gyümölcsös-oldal (SzP 2006), Malom-mező (BG 2021), Szőlő-oldal (BG 2021); Zádorfalva: Latrány-völgy (SzP 2007), Nagy-szőlő (SzP 2006), Szuha-völgy (SzP 2021). [!7588.4], [!7689.4].

1509. Stachys recta L. - Ined.: Ragály: Csornok (SzP 2010), Gerenda-oldal (SzP 2009), Ortvány-kert (SzP 2008). [!7589.3].

1513. Stachys germanica L. - Ined.: Felsőnyárád: Őr-hegy (BG 2021); Jákfalva: Jákvarcsó (BG 2010). [!7689.3], [!7689.4].

1519. Glechoma hirsuta Waldst. et Kit. - Ined.: Alsószuha: Jegenye-völgy (SzP 2008). [!7689.1].

1527. Acinos arvensis (Lam.) Dandy - Ined.: Felsőnyárád: Jákfalvi-dűlő (BG 2021), Mestergaz (BG 2021); Kurityán: Malom-mező (BG 2021); Zádorfalva: Rakottyás-tető (SzP 2006). [!7688.2], [!7689.4].

1541. Lycopus europaeus L. - Ined.: Ragály: Belterület (SzP 2005), Dobrosó-oldal (SzP 2007). [!7589.3].

1549. Mentha arvensis L. - Ined.: Dövény: Alsó-rét (SzP 2021); Zubogy: Kert alja (BG 2021), Suba-oldal (BG 2020), Suba-tető (BG 2020), Szuhucer (BG 2021), Tanya alja (BG 2021). [!7689.1], [!7689.3].

1551. Mentha $\times$ verticillata L. (Mentha aquatica L. $\times$ arvensis L.) - Ined.: Dövény: Alsó-rét (SzP 2021), Kötél-föld (SzP 2021). [!7689.3].

1557. Salvia glutinosa L. - Ined.: Alsószuha: Feneketlen (SzP 2007); Szuhafő: Pincék alja (SzP 2008); Zádorfalva: Latrány-völgy (SzP 2008), Ragyás-szőlő (SzP 2006). [!7588.4], [!7688.2], [!7689.1].

1562. Salvia nemorosa L. - Ined.: Szuhafő: Pincék alja (SzP 2008). [!7588.4].

1579. Solanum nigrum L. - Ined.: Felsőnyárád: Jákfalvi-dűlő (SzP 2006). [!7689.4].

1583. Datura stramonium L. - Ined.: Kurityán: Belső-szög (SzP 2006); Szuhafő: Szuha-völgy (SzP 2021). [!7588.4],[!7689.4].

1596. Verbascum blattaria L. - Ined.: Alsószuha: Dobos-tető (SzP 2009), Gyámol-völgy (SzP 2009); Felsőnyárád: Belterület (SzP 2006); Kurityán: Belterület (SzP 2006); Ormosbánya: Kavicsos (SzP 2006); Ragály: Belterület (SzP 2005), Tamáska (SzP 2021). [!7589.3], [!7689.1], [!7689.4].

1597. Verbascum chaixii Will. subsp. austriacum (Schott) Hayek - Ined.: Alsószuha: Feneketlen (SzP 2021), Határ-völgy (SzP 2009), Ritka-dűlő (SzP 2006); Dövény: Gödör-köz-dűlő (SzP 2009), Pencs-tető (SzP 2009); Ragály: Tamáska (SzP 2021). [!7589.3], [!7689.1].

1606. Scrophularia umbrosa Dumort. - Ined.: Dövény: Szuha (SzP 2009); Izsófalva: Szuha (SzP 2008); Kurityán: Fekete-völgy (BG 2021). A kurityáni példány subsp. neesii (Wirtg.) E. Mayer. [!7689.1], [!7689.4].

1622. Digitalis grandiflora Mill. - Ined.: Alsószuha: Határ-völgy (SzP 2010), Kocka-lápa-bérc (SzP 2010), Virág-oldal (SzP 2021); Dövény: Pencs-oldal (SzP 2009), Pencs-tető (SzP 2009), Varcsó-völgy (SzP 2008). [!7689.1], [!7689.3].

1628. Pseudolysimachion spicatum (L.) Opiz - Ined.: Alsószuha: Feneketlen (SzP 2021), Hegyes-hegy (SzP 2021), Megye-berek (SzP 2021), Ritka-oldal (SzP 2021); Dövény: Pencs-oldal (SzP 2021). [!7689.1].

1631. Veronica beccabunga L. - Ined.: Dövény: Belterület (SzP 2008); Felsőnyárád: Kelecsényi-útonfelüli-dűlő (BG 2020); Izsófalva: Mogyoróska (SzP 2021); Zádorfalva: Varjas-völgy (SzP 2021). [!7688.2], [!7689.3], [!7689.4].

1635. Veronica anagallis-aquatica L. - Ined.: Felsőnyárád: Csörgős-patak (BG 2021), Kelecsényi-útonfelüli-dűlő (BG 2021), Szuha (SzP 2006); Imola: Belterület, Imola-patak (SzP 2006); Kurityán: Feketevölgy (BG 2021); Ragály: Belterület (SzP 2006); Rudolftelep: Belterület, Mák-patak (SzP 2006); Szuhafő: Belterület, Szuha (SzP 2021), Korlát-patak (SzP 2003); Zádorfalva: Belterület, Szuha (SzP 2021), Szuhavölgy (SzP 2006), Varjas-völgy (SzP 2006). [!7588.4], [!7589.3], [!7688.2], [!7689.4], [!7690.3].

1636. Veronica prostrata L. - Ined.: Felsőnyárád: Kelecsényi-úton-aluli-dűlő (BG 2021), Ốr-hegy (BG 2021), Pincék (BG 2021); Kurityán: Susa-tető (BG 2021). [!7689.4].

1639. Veronica teucrium L. - Ined.: Felsőkelecsény: Aradvány alja (BG 2021); Felsőnyárád: Mestergaz (SzP 2006). [!7689.2], [!7689.4].

1647. Veronica serpyllifolia L. - Ined.: Dövény: Alsó-rét (SzP 2021), Pencs alja (SzP 2021); Felsőnyárád: Kelecsényi-úton-aluli-dűlő (BG 2021), Szuha alja (BG 2021); Imola: Ivó-kút (SzP 2021). [!7589.3], [!7689.1], [!7689.3], [!7689.4].

1656. Veronica persica Poir. - Ined.: Alsószuha: Alsó-rét (SzP 2021), Kánya-völgy (SzP 2021); Dövény: Alsó-rét (SzP 2021), Belterület (SzP 2006), Kötél-föld (SzP 2021), Pencs alja (SzP 2021); Felsőnyárád: Kelecsényi-úton-aluli-dűlő (BG 2021), Szuha alja (BG 2021); Izsófalva: Kavicsos (SzP 2021); Jákfalva: Köteles alja (SzP 2021); Ragály: Barom-szer (SzP 2021), Ortvány-kert (SzP 2021); Zubogy: Kert alja (BG 2021), Szuhucer (BG 2021). [!7589.3], [!7689.1], [!7689.3], [!7689.4].

1663. Melampyrum pratense L. - Ined.: Alsószuha: Kánya-fő (SzP 2014), Kocka-lápa-bérc (SzP 2010), Virág-oldal (SzP 2021); Dövény: Pencs-tető (SzP 2009). [!7689.1].

1665. Melampyrum nemorosum L. - Ined.: Szuhafő: Pincék alja (SzP 2006). [!7588.4]. 
1668. Euphrasia stricta Wolf - Ined.: Ragály: Dobrosó-oldal (SzP 2007); Zádorfalva: Berek eleje (SzP 2006), Varjas-part (SzP 2005). [!7589.3], [!7688.2].

1671. Odontites vernus (Bellardi) Dumort. subsp. serotinus (Dumort.) Corb. - Ined.: Zádorfalva: Ragyásszőlő (SzP 2009). [!7688.2].

1723. Galium boreale L. - Ined.: Múcsony: Cseres-szőlő (BG 2021). [!7790.1].

1762. Sambucus nigra L. - Ined.: Alsószuha: Alsó-rét (SzP 2000), Ritka-dűlő (SzP 2000). [!7689.1].

1797. Campanula glomerata L. - Ined.: Dövény: Pencs-tető (SzP 2006); Zubogy: Bodon alja (SzP 1996). [!7689.1], [!7689.2].

1799. Campanula cervicaria L. - Ined.: Dövény: Pencs-tető (SzP 2009); Szuhafő: Pető-háza (SzP 2009), Pető-házi-szőlő (SzP 2009). [!7688.2], [!7689.1].

1800. Campanula sibirica L. - Ined.: Alsószuha: Feneketlen (SzP 2007), Hegyes-hegy (SzP 2006), Kányafő (SzP 2010), Vad-répás (SzP 2006); Ragály: Gerenda-oldal (SzP 2008), Ortvány-kert (SzP 2008). [!7589.3], [!7689.1].

1805. Campanula persicifolia L. - Ined.: Dövény: Varcsó (SzP 2008). [!7689.3].

1807. Campanula patula L. - Ined.: Alsószuha: Alsó-rét (SzP 2006), Feneketlen (SzP 2021), Ritka-dűlő (SzP 2021); Dövény: Alsó-rét (SzP 2006), Felső-rét (SzP 2006), Kötél-föld (SzP 2006); Jákfalva: Gyökérkúti-rét (SzP 2006). [!7689.1], [!7689.3].

1828. Aster linosyris (L.) Bernh. - Ined.: Alsószuha: Feneketlen (SzP 2021), Szilas-oldal (SzP 2021). [!7689.1].

1846. Gnaphalium sylvaticum L. - Ined.: Sajókaza: Domonyó-hegy (BG 2015). [!7789.1].

1853. Inula hirta L. - Ined.: Múcsony: Cseres-szőlő (BG 2021); Szuhafő: Pincék alja (SzP 2010). [!7588.4], [!7790.1].

1867. Bidens tripartita L. - Ined.: Felsőnyárád: Csörgős-patak (BG 2020); Imola: Belterület, Imola-patak (SzP 2021); Kurityán: Szuha (BG 2020); Rudabánya: Ravasz-lyuk (BG 2020); Zubogy: Zúgó-völgy (BG 2020). [!7589.3], [!7689.2], [!7689.4].

1872. Helianthus tuberosus L. s. l. - Ined.: Felsőkelecsény: Csörgős-patak (BG 2020). [!7689.2].

1876. Ambrosia artemisiifolia L. - Ined.: Zádorfalva: Latrány-völgy (SzP 2007), Nagy-szőlő alja (SzP 2007), Ragyás-szőlő (SzP 2010), Szuha-völgy (SzP 2009), Varjas-völgy (SzP 2010). [!7588.4], [!7688.2].

1881. Xanthium italicum Moretti - Ined.: Izsófalva: Kavicsosi-bányató (SzP 2011); Ragály: Dobrosó-oldal (SzP 2011); Szuhafő: Szuha-völgy (SzP 2021); Zádorfalva: Belterület (SzP 2021), Latrány-völgy (SzP 2011), Nagy-szőlő alja (SzP 2011). Sajó-völgy: Múcsony: Ragályi-szög (SzP 2011). [!7588.4], [!7589.3], [!7688.2], [!7689.4], [!7790.1].

1894. Anthemis tinctoria L. - Ined.: Felsőkelecsény: Aradvány alja (BG 2020); Felsőnyárád: Mestergaz (SzP 2008), Válós-út alja (SzP 2006); Zádorfalva: Ragyás-szőlő (SzP 2010). [!7688.2], [!7689.2], [!7689.4].

1913. Tanacetum vulgare L. - Ined.: Alsószuha: Alsó-rét (SzP 2021), Hegyes-hegy (SzP 2021), Kányavölgy (SzP 2021); Dövény: Alsó-rét (SzP 2021). [!7689.1], [!7689.3].

1914. Tanacetum corymbosum (L.) Sch. Bip. - Ined.: Dövény: Pencs-tető (SzP 2009); Szuhafő: Pincék alja (SzP 2008). [!7588.4], [!7689.1].

1918. Leucanthemum vulgare Lam. s. str. - Ined.: Alsószuha: Alsó-rét (SzP 2000), Ritka-dűlő (SzP 2000); Dövény: Alsó-rét (SzP 2000). [!7689.1], [!7689.3].

1933. Petasites hybridus (L.) G. Gaertn., G. Mey. et Scherb. - Ined.: Alsószuha: Szuha (SzP 2021); Ragály: Csörgős-patak (SzP 2006); Trizs: Csörgős-lapos (SzP 2006); Zádorfalva: Szuha-völgy (SzP 2006). [!7589.3], [!7688.2], [!7689.1].

1943. Senecio vulgaris L. - Ined.: Imola: Ivó-kút (SzP 2021). [!7589.3].

1955. Senecio germanicus Wallr. - Ined.: Felsőnyárád: Mestergaz (BG 2019). [!7689.4].

1965. Echinops sphaerocephalus L. - Ined.: Alsószuha: Bakócz (SzP 2006); Dövény: Pencs-oldal (SzP 2013), Tófenék (SzP 2006); Imola: Avas-oldal (SzP 2021); Ragály: Batyik-völgy (SzP 2006), Dégány (SzP 2006), Tamáska (SzP 2006). [!7589.3], [!7689.1], [!7689.3].

1973. Carduus nutans L. - Ined.: Rudolftelep: Vattai-oldal (SzP 2006). [!7690.3].

1975. Carduus crispus L. - Ined.: Izsófalva: Cseres-dűlő (BG 2021); Jákfalva: Süveges alja (BG 2021); Ragály: Határnál (BG 2020); Zubogy: Doma alja (BG 2021). [!7689.1], [!7689.3], [!7790.1].

1993. Serratula tinctoria L. - Ined.: Múcsony: Cseres-szőlő (BG 2021). [!7790.1].

2003. Centaurea cyanus L. - Ined.: Ragály: Barom-szer (SzP 2007), Belterület (SzP 2005), Ortvány-kert (SzP 2006), Pénzvermek (SzP 2009); Sajókaza: Palotás (BG 2017). [!7589.3], [!7789.1].

2008.3. Centaurea scabiosa L. subsp. scabiosa - Ined.: Alsószuha: Lengyel-oldal (SzP 2021), Megyeberek (SzP 2021). [!7689.1].

2010.2. Centaurea stoebe L. subsp. micranthos (Gugler) Hayek - Ined.: Dövény: Pencs-oldal (SzP 2021). [!7689.1]. 
2016. Hypochoeris maculata L. - Ined.: Felsőnyárád: Kazai-dúlő (SzP 2008), Őr-hegy (BG 2021); Izsófalva: Szekeres (SzP 2021); Kurityán: Malom-mező (BG 2021); Múcsony: Cseres-szőlő (SzP 2006); Ragály: Ortvány-kert (SzP 2005); Rudolftelep: Cseres-dúlő (BG 2016), Felső-rét (SzP 2006), Homonc (BG 2016); Szuhafő: Zsilip-tető (SzP 2010); Trizs: Forrás-völgy (SzP 2021). [!7588.4], [!7589.3], [!7689.4], [!7690.3], [!7790.1].

2032. Tragopogon dubius Scop. - Ined.: Kurityán: Malom-mező (BG 2021), Szőlő-oldal (BG 2021). [!7689.4].

2033. Tragopogon orientalis L. - Ined.: Felsőnyárád: Kelecsényi-úton-aluli-dűlő (BG 2020); Kurityán: Malom-mező (BG 2021). [!7689.4].

2042. Lactuca saligna L. - Ined.: Zádorfalva: Belterület (SzP 2021). [!7688.2].

2124. Alisma plantago-aquatica L. - Ined.: Imola: Belterület, Imola-patak (SzP 2021). [!7589.3].

2144. Anthericum ramosum L. - Ined.: Alsószuha: Feneketlen (SzP 2021); Izsófalva: Mogyoróska (SzP 2006); Kurityán: Szőlő-oldal (BG 2013). [!7689.1], [!7689.4].

2159. Ornithogalum umbellatum L. s. l. - Ined.: Alsószuha: Kis-kánya-fő (SzP 2021), Megye-berek (SzP 2021); Izsófalva: Alsó-rét (SzP 2006). [!7689.1], [!7789.2].

2198. Asparagus officinalis L. - Ined.: Ragály: Gerenda-oldal (SzP 2009), Ortvány-kert (SzP 2008). [!7589.3].

2251. Iris pseudacorus L. - Ined.: Ragály: Batyik-völgy (SzP 1996). [!7589.3].

2359. Melica nutans L. - Ined.: Felsőnyárád: Kis-erdő (SzP 2006). [!7689.4].

2396.1. Elymus hispidus (Opiz) Melderis subsp. hispidus - Ined.: Jákfalva: Meleg-oldal (BG 2021). [!7689.3].

2561. Scirpus sylvaticus L. - Ined.: Alsószuha: Alsó-rét (SzP 2000), Ritka-dűlő (SzP 2006); Dövény: Alsórét (SzP 2000), Felső-rét (SzP 2000), Kötél-föld (SzP 2006); Jákfalva: Alsó-rét (SzP 2000), Falu-rét (SzP 2006). [!7689.1], [!7689.3]. 